http://kitaibelia.unideb.hu/

ISSN 2064-4507 (Online) • ISSN 1219-9672 (Print)

(C) Department of Botany, University of Debrecen, Hungary

24(1): 66-93.; 2019

DOI: $10.17542 /$ kit.24.66

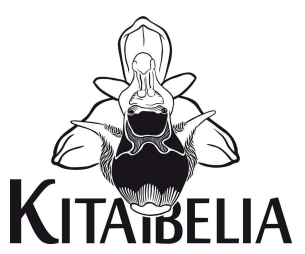

\title{
Zárt lösztölgyes maradványok a Mezőföldön (Pulmonario mollis-Quercetum roboris Kevey 2008)
}

\author{
KEVEY Balázs ${ }^{1 *}$, HoRváth András ${ }^{2}$ \& LENDVAI Gábor ${ }^{3}$ \\ (1) Pécsi Tudományegyetem, Ökológiai Tanszék, H-7624 Pécs, Ifjúság u. 6.; keveyb@gamma.ttk.pte.hu \\ (2) Vak Bottyán Általános Iskola és Gimnázium, H-7081 Simontornya, Hunyadi u. 15.
}

(3) H-7000 Sárbogárd, Tompa Mihály u. 38/C.

\section{Remnants of closed oak woods on loess in the Mezőföld (Pulmonario mollis-Quercetum roboris Kevey 2008)}

\begin{abstract}
The phytosociological characterization of closed oak forests occurring in the loess-covered part of Central Hungary (Mezőföld) is presented. Such forest fragments are found very sporadically in that predominantly treeless region, mostly in semi-dry habitats of north-facing hillsides. This plant community represents an intermediate stage between open steppe woodland (Aceri tatarici-Quercetum pubescentisroboris) and closed mesic oak-hornbeam forests (Corydali cavae-Carpinetum). Analyses of 20 phytosociological samples using multivariate grouping methods (cluster analysis, principal coordinates analysis) showed a clear difference between these samples and samples of similar communities occurring in the area. In the species composition the characteristic elements of dry and mesic oak forests (Quercetea pubescentis-petraeae, Quercetalia cerridis, Aceri tatarici-Quercion and Fagetalia, respectively) played a major role. On the other hand, dry grassland species (Festuco-Brometea, Festucetalia valesiacae, Festucion rupicolae, etc.) were much less significant than in steppe woodlands. In terms of chorology, European and sub-Mediterranean floristic elements were dominant in the samples, while the proportion of continental elements was substantially smaller than that in steppe woodlands. As a result, our samples were identified with the plant association Pulmonario mollis-Quercetum roboris Kevey 2008, which is classified into the suballiance Polygonato latifolio-Quercenion roboris Kevey 2008 in the phytosociological system.
\end{abstract}

Keywords: Central Hungary, forest vegetation on loess, Syntaxonomy

Összefoglalás - Jelen tanulmány a Magyarország középső részén levő Mezőföld zárt lösztölgyeseinek (Pulmonario mollis-Quercetum roboris) cönológiai elemzését tartalmazza 20 felvétel alapján. Az erdőtlen tájon ez az asszociáció igen szórványosan mutatkozik. Fragmentumai félszáraz-félüde termőhelyeken fordulnak elő, és átmenetet képeznek a száraz nyílt lösztölgyesek (Aceri tatarici-Quercetum pubescentisroboris) és az üde talajú gyertyános-tölgyesek (Corydali cavae-Carpinetum) között. E zárt lösztölgyesek (Pulmonario mollis-Quercetum roboris) az alföldi lösztáblákon a homokvidékekről ismert - ugyancsak félszáraz-félüde talajú - zárt homoki tölgyeseket (Convallario-Quercetum roboris) helyettesítik. A sokváltozós elemzések (cluster-analízis, főkoordináta-analízis) révén a zárt (Pulmonario mollis-Quercetum roboris) és a nyílt (Aceri tatarici-Quercetum pubescentis-roboris) lösztölgyesek elkülönültek egymástól. A társulás felépítésében a száraz erdők (Quercetea pubescentis-petraeae, Quercetalia cerridis, Aceri tatariciQuercion) és az üde erdők (Fagetalia) karakterfajai fontos szerepet játszanak. A száraz gyepek elemei (Festuco-Brometea, Festucetalia valesiacae, Festucion rupicolae stb.) ezzel szemben a nyílt lösztölgyesekhez (Aceri tatarici-Quercetum pubescentis-roboris) képest erősen visszaszorulnak. A flóraelemek között az európai és a szubmediterrán fajok a meghatározóak, míg a kontinentális elemek alárendeltebb szerepet töltenek be, mint a nyílt lösztölgyesekben. A vizsgált zárt lösztölgyes (Pulmonario mollis-Quercetum roboris Kevey 2008) a Polygonato latifolio-Quercenion roboris Kevey 2008 alcsoportba (suballiance) sorolható.

Kulcsszavak: erdei löszvegetáció, Közép-Magyarország, szüntaxonómia 


\section{Bevezetés}

Kutatócsoportunk 2004-ben kezdte meg a Mezőföld és peremvidéke tatárjuharos-tölgyeseinek (Aceri tatarici-Quercetum pubescentis-roboris) és zárt lösztölgyeseinek (Pulmonario mollis-Quercetum roboris) felmérését (vö. KEVEY 2008, LENDVAI et al. 2014a, 2014b, KEVEY et al. 2015, 2018, HoRVÁTH et al. 2017, PURGER et al. 2014). Közleményünkben a Mezőföld zárt lösztölgyeseit jellemezzük 20 cönológiai felvétel alapján.

\section{Anyag és módszer}

\section{Kutatási terület jellemzése}

Kutatási területünk az Alföld flóravidékéhez (Eupannonicum) tartozó Mezőföld lösztáblái. A táj BoRHIDI (1961) klímazonális térképe szerint az erdőssztyepp zónába tartozik. A Mezőföld erdősültsége már a II. József-kori katonai felmérés térképein is hasonlóan alacsony volt, mint jelenleg. Az egykori száraz tölgyesekből csak néhány fragmentum maradt meg hírmondóként. A részletes terepbejárás után először a tatárjuharos-tölgyesekből (Aceri tatariciQuercetum pubescentis-roboris) készült cönológiai felvételeket közöltük (LENDVAI et al. 2014a). Ezen erdőssztyep foltok olykor zártabb erdőfoltokkal érintkeznek, amelyeket az Alföld egyéb pontjairól közölt zárt lösztölgyesekkel (Pulmonario mollis-Quercetum roboris) sikerült azonosítanunk (KeVEY 2008, 2011, 2016, KEVEY et al. 2015, 2018). Töredékes állományaikat néhol csak kastélyparkok (Dég, Előszállás) őrizték meg. A vizsgált állományok 103 és 170 m tengerszint feletti magasság között fordulnak elő. Többségük a löszvölgyek északias és keleti kitettségű, 5-30 fokos lejtőin található, barna erdőtalajon. Mikroklímájuk viszonylag meleg és félszáraz, talajuk a félszáraz-félüde tartományba sorolható.

\section{Alkalmazott módszerek}

A cönológiai felvételek a Zürich-Montpellier növénycönológiai iskola (BECKING 1957, BRAUNBLANQUET 1964) hagyományos kvadrát-módszerével készültek. A felvételek táblázatos öszszeállítása, valamint a karakterfajok csoportrészesedésének és csoporttömegének számítása az „NS” számítógépes programcsomaggal (KEVEY \& HIRMANN 2002) történt. A felvételkészítés és a hagyományos statisztikai számítások - kissé módosított - módszere KEVEY (2008) tanulmányában megtalálható. Az állományszerkezeti vizsgálatok során a szintek borítottságát és magasságát becsléssel állapítottuk meg. Hasonlóan jártunk el a fák törzsátmérőjének meghatározásakor. Ez esetben csak a felső lombkoronaszint fáit vettük figyelembe, s a leggyakoribb fák törzsátmérőjét becsültük. Amennyiben 1-1,5 m átmérőjű famatuzsálemek is voltak a felvett állományban, ezek száma alapján a becsült értéket 5-10 cm-rel növeltük. A SYN-TAX 2000 program segítségével (PoDANi 2001) sokváltozós elemzéseket is végeztünk. E téren részben bináris alapú ordinációt (Ordinációs módszer: főkoordináta analízis; Hasonlósági index: Baroni-Urbani-Buser) és szintén bináris alapú klasszifikációt (Klasszifikációs módszer: teljes lánc; Hasonlósági index: Baroni-Urbani-Buser) készítettünk. E módszerekkel hasonlítottuk össze a Mezőföld zárt (Pulmonario mollis-Quercetum roboris) és nyílt (Aceri tatarici-Quercetum pubescentis-roboris: LENDVAI et al. 2014a) lösztölgyeseit. A vizsgálatokba belevontuk a korábban más tájakról közölt (Zámolyi-medence: KEVEY 2008, KEVEY et al. 2015; Kerecsend: KEVEY 2011; Harkány-Nagynyárádi-sík: KeveY 2016) zárt lösztölgyes (Pulmonario mollis-Quercetum roboris) felvételeket is. 
A fajok esetében KIRÁLY (2009), a társulásoknál pedig BORHIDI \& KEVEY (1996), BORHIDI et al. (2012), ill. KEVEY (2008) nómenklatúráját követjük. A társulástani és a karakterfajstatisztikai táblázatok felépítése az újabb eredményekkel (OBERDORFER 1992, Mucina et al. 1993, BoRHIDI et al. 2012, KEVEY 2008) módosított Soó (1980) féle cönológiai rendszerre épül. A növények cönoszisztematikai besorolásánál is elsősorban Soó $(1964,1966,1968$, 1970, 1973, 1980) Synopsis-ára támaszkodtunk, de figyelembe vettük az újabb kutatási eredményeket is (vö. BORHIDI 1993, 1995, HORVÁTH et al. 1995).

\section{Eredmények}

Szintezettség

A vizsgált zárt lösztölgyesek felső lombkoronaszintje az állomány korától és a termőhelyi viszonyoktól függően 20-27 m magas, és közepes, vagy erősebb záródást mutat (50-80\%). Állandó (K: IV-V) fája csak az idegenhonos Celtis occidentalis. A helyenként nagyobb tömegben (A-D: 3-4) előforduló fái az Acer campestre, a Celtis occidentalis, a Fraxinus ornus, a Fraxinus excelsior, a Quercus pubescens, a Quercus robur és az Ulmus minor. E viszonylag jól zárt szintben lékek csak ritkábban fordulnak elő. A fák átlagos törzsátmérője általában 40$50 \mathrm{~cm}$. Két esetben kaptunk szélsőségesen magas, $70 \mathrm{~cm}$-es értéket (1-3. táblázat: 7. és 9 . felvétel). E két felvételben ugyanis hatalmas - $1 \mathrm{~m}$-nél is nagyobb átmérőjű - famatuzsálemek is voltak. Az alsó lombkoronaszint fejlettebb, mint a nyílt lösztölgyeseknél (Aceri tatarici-Quercetum pubescentis-roboris), fái a felső lombkoronaszintben levő lékeket többnyire elzárják. A fák magassága 12-20 m, borításuk pedig 20-60\%. Állandó (K: IV) fája csak a Celtis occidentalis és az Ulmus minor. Nagyobb tömeget (A-D: 3) az Acer campestre, a Fraxinus ornus és az Ulmus minor képez.

A cserjeszint fejlettsége igen változó. Magassága 2-4 m, borítása pedig 25-70\%. Állandó (K: IV-V) elemei a Celtis occidentalis, a Crataegus monogyna, a Sambucus nigra és az Ulmus minor. Nagyobb tömeget (A-D: 3-4) a Celtis occidentalis, a Cornus mas, a Crataegus monogyna, a Rhamnus catharticus és az Ulmus minor képez. Az alsó cserjeszint (újulat) szintén változóan fejletlen (1-50\%). Állandó (K: IV-V) fajai az alábbiak: Acer campestre, Celtis occidentalis, Crataegus monogyna, Euonymus europaeus, Euonymus verrucosus, Ligustrum vulgare, Prunus spinosa, Sambucus nigra, Ulmus minor. E szintben fáciest (A-D: 3) csak a Hedera helix képez.

A gyepszint borítása 10-90\%. Állandó elemei (K: IV-V) a következők: Alliaria petiolata, Anthriscus cerefolium, Ballota nigra, Brachypodium sylvaticum, Chaerophyllum temulum, Chelidonium majus, Dactylis polygama, Fallopia dumetorum, Galium aparine, Geranium robertianum, Geum urbanum, Lapsana communis, Polygonatum latifolium, Ranunculus ficaria, Stellaria media, Urtica dioica, Veronica sublobata, Viola hirta, Viola suavis. E szintben néhány lágyszárú növény fáciest (A-D: 3-4) képezhet: Corydalis cava, Geranium robertianum, Polygonatum latifolium, Ranunculus ficaria, Vinca minor, Viola suavis.

Fajkombináció

Sokváltozós statisztikai elemzések eredményei

A zárt (Pulmonario mollis-Quercetum roboris) és nyílt (Aceri tatarici-Quercetum pubescentisroboris) lösztölgyesek a sokváltozós elemzések (klaszter-analízis, főkoordináta-analízis) során az első megközelítésre még nem különültek el egyértelműen (Elektronikus melléklet 1-2. ábra). Ezután a nyílt lösztölgyesekből eltávolítottunk öt átmeneti jellegű felvételt, majd ezután a két társulás felvételei egyértelműen elkülönültek (1-2. ábra). 


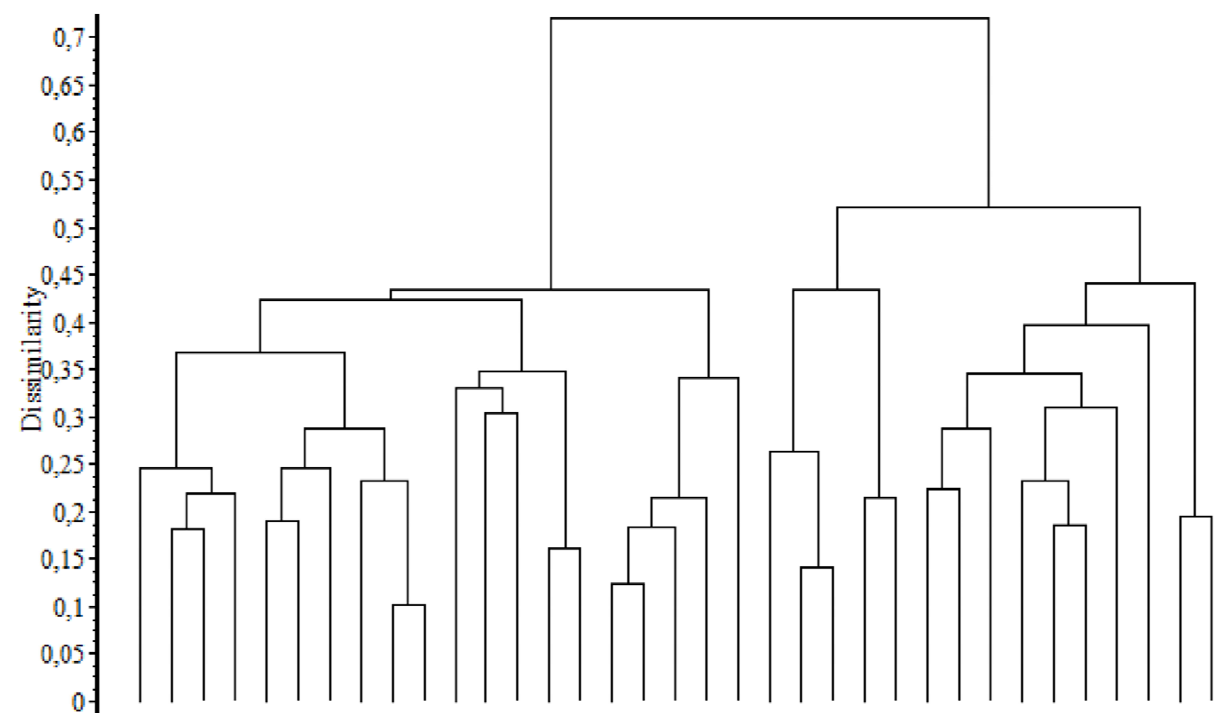

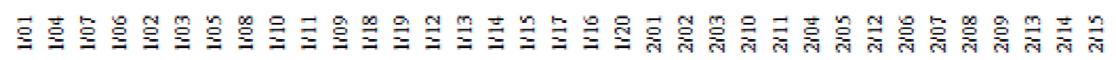

1. ábra Zárt és nyílt lösztölgyes felvételek bináris dendrogramja (hasonlósági index: Baroni-Urbani-Buser; osztályozó módszer: teljes lánc)

Fig. 1 Binary dendrogram of samples from closed oak forests and open steppe woodlands (similarity coefficient: Baroni-Urbani-Buser; clustering method: complete link)

1/1-20: Pulmonario mollis-Quercetum roboris (Kevey \& Lendvai ined.)

2/1-20: Aceri tatarici-Quercetum pubescentis-roboris (LENDVAI et al. 2014a)

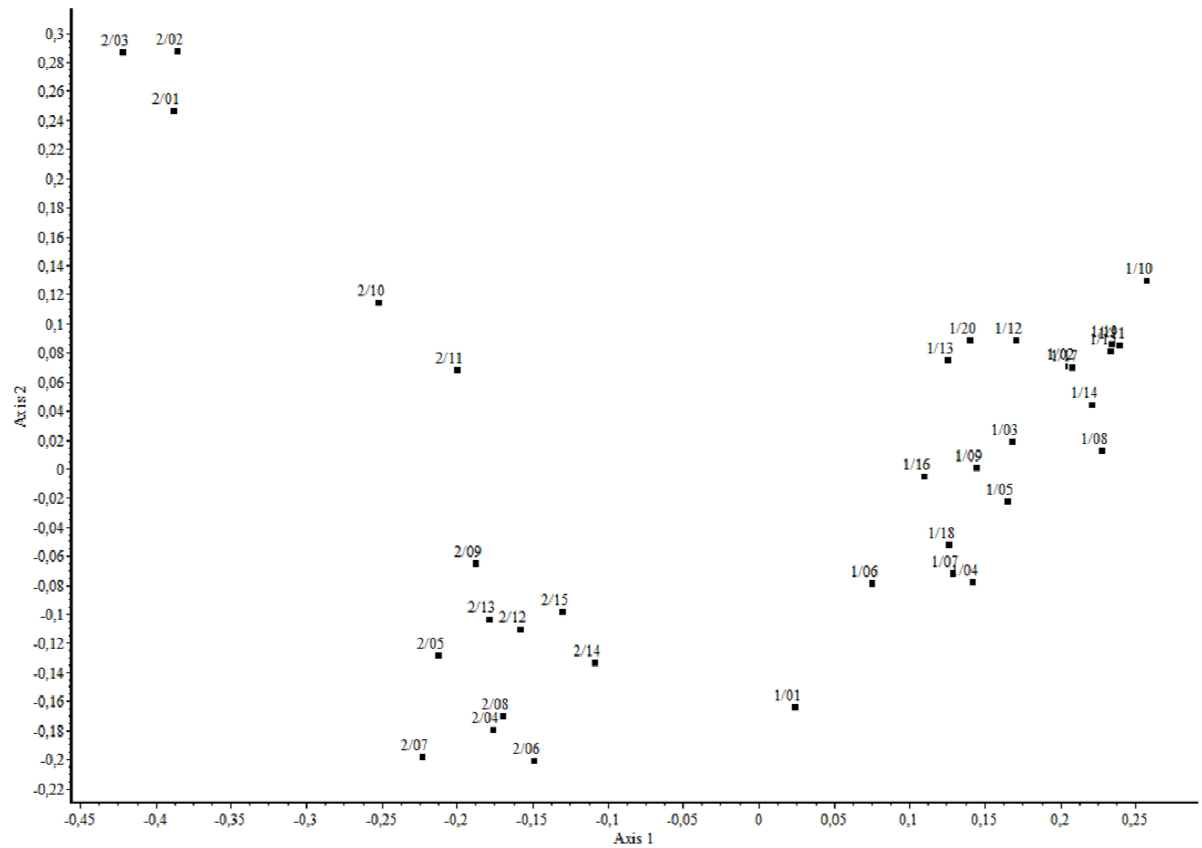

2. ábra Zárt és nyílt lösztölgyes felvételek bináris ordinációs diagramja

(hasonlósági index: Baroni-Urbani-Buser; ordinációs módszer: főkoordináta-analízis)

Fig. 2 Binary ordination diagram of samples from closed oak forests and open steppe woodlands (similarity coefficient: Baroni-Urbani-Buser; ordination method: principal coordinates analysis)

1/1-20: Pulmonario mollis-Quercetum roboris (Kevey \& Lendvai ined.)

2/1-15: Aceri tatarici-Quercetum pubescentis-roboris (LENDVAI et al. 2014a) 
A Mezőföld és peremvidéke, valamint a Kerecsendi-erdő zárt lösztölgyeseinek ordinációs vizsgálatával (3-4. ábra) az egyes tájak többé-kevésbé elkülönültek. Viszonylag külön csoportot alkotnak a Harkány-Nagynyárádi-sík és a Tolnai-hegyhát (3. ábra), valamint a Kerecsendi-erdő (4. ábra) felvételei. A Mezőföld felvételi anyaga leginkább a Zámolyi-medence felvételeivel mutatja a legnagyobb hasonlóságot, azokkal kevert csoportot képez (3-4. ábra).

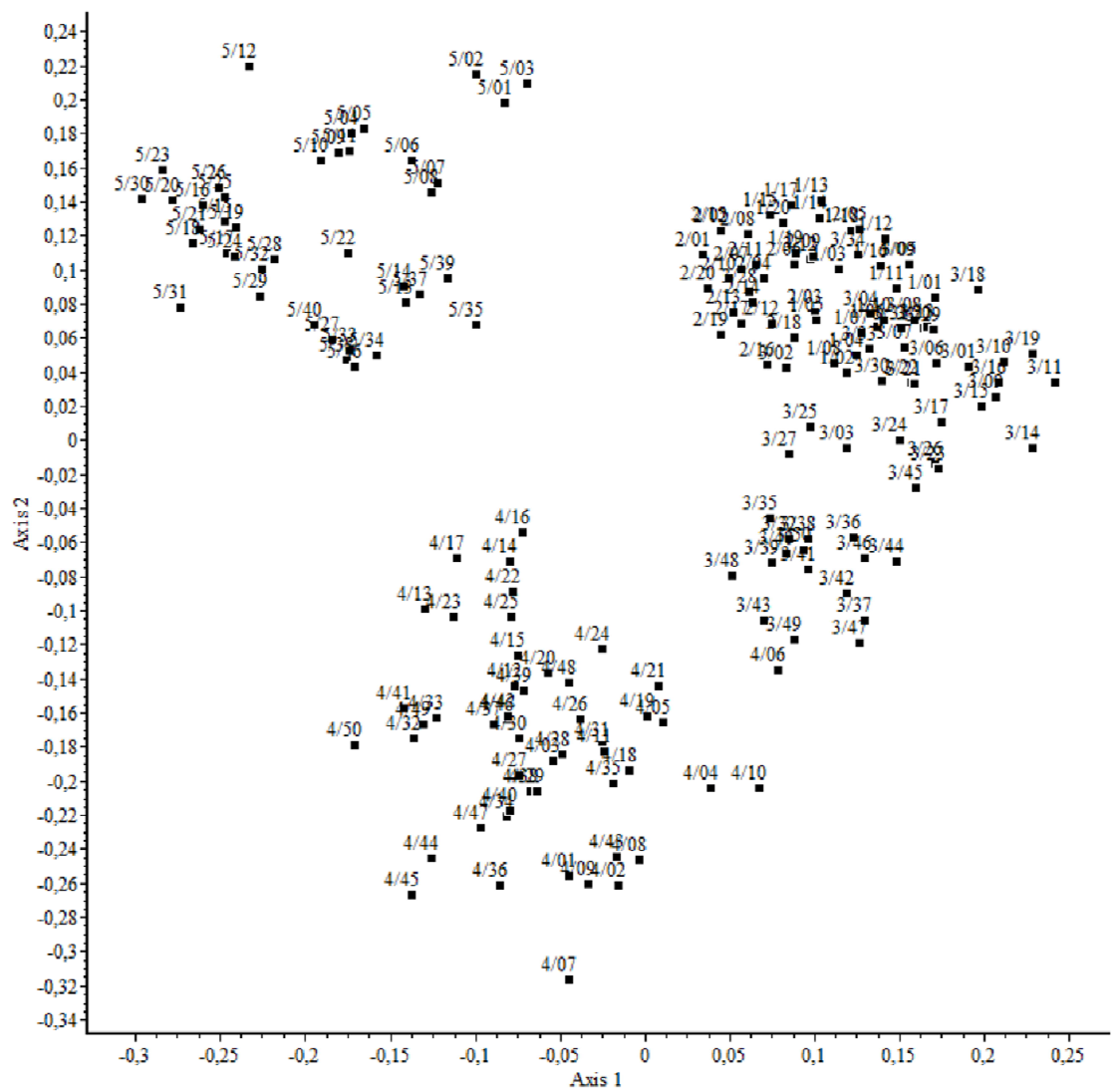

3. ábra Zárt lösztölgyes (Pulmonario mollis-Quercetum roboris), felvételek bináris ordinációs diagramja I. (hasonlósági index: Baroni-Urbani-Buser; ordinációs módszer: főkoordináta-analízis)

Fig. 3 Binary ordination diagram of samples from closed oak forests I.

(similarity coefficient: Baroni-Urbani-Buser; ordination method: principal coordinates analysis)

1/1-20: Mezőföld (Kevey \& Lendvai ined.); 2/1-20: Kerecsend (KEvey 2011);

3/1-50: Zámolyi-medence (KEvEY et al. 2015); 4/1-50: Tolnai-hegyhát (KEVEY et al. 2018); 5/1-40: Harkány-Nagynyárádi-sík (KEVEY 2016)

\section{Állandósági osztályok eloszlása}

A 20 cönológiai felvétel alapján a vizsgált zárt lösztölgyesekből 17 konstans és 12 szubkonstans faj szerepel az alábbiak szerint: K V: Alliaria petiolata, Anthriscus cerefolium, Ballota nigra, Brachypodium sylvaticum, Celtis occidentalis, Crataegus monogyna, Euonymus europaeus, Fallopia dumetorum, Geum urbanum, Lapsana communis, Polygonatum latifolium, Prunus spinosa, Sambucus nigra, Ulmus minor, Veronica sublobata, Viola hirta, Viola suavis. - K IV: Acer campestre, Chaerophyllum temulum, Chelidonium majus, Dactylis polygama, Geranium robertianum, Ligustrum vulgare, Ranunculus ficaria, Rhamnus catharticus, Robinia pseudo- 
acacia, Stellaria media, Urtica dioica, Viburnum lantana. A társulásból továbbá 8 akcesszórikus (K III), 32 szubakcesszórikus (K II) és 124 akcidens (K I) faj került elő (1. táblázat; 5. ábra). Az állandósági osztályokat tekintve tehát az akcidens (K I) elemek mellett a konstans (K V) fajoknál mutatkozik egy gyengébb második maximum.

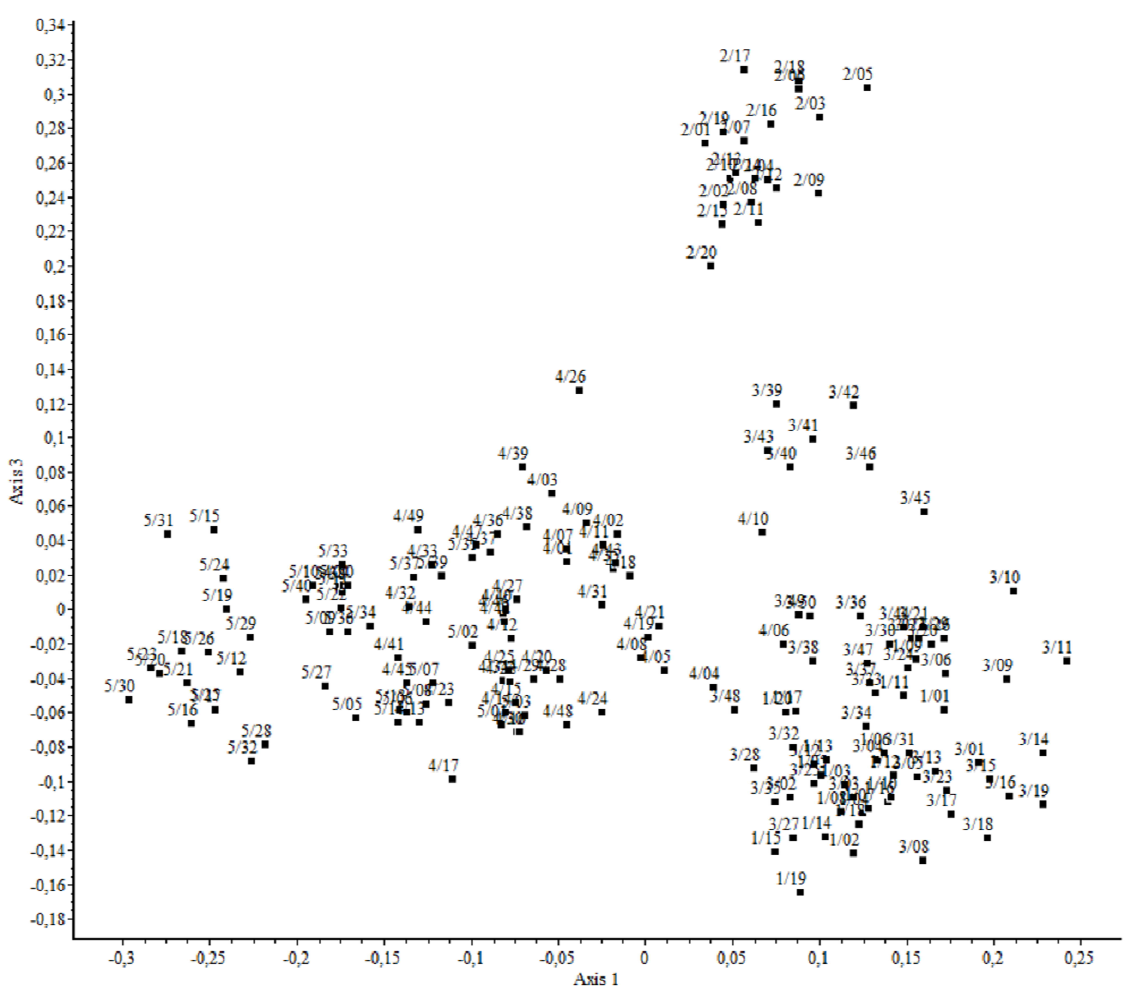

4. ábra Zárt lösztölgyes (Pulmonario mollis-Quercetum roboris), felvételek bináris ordinációs diagramja

II. (hasonlósági index: Baroni-Urbani-Buser; ordinációs módszer: főkoordináta-analízis)

Fig. 4 Binary ordination diagram of samples from closed oak forests II.

(similarity coefficient: Baroni-Urbani-Buser; ordination method: principal coordinates analysis)

1/1-20: Mezőföld (Kevey \& Lendvai ined.); 2/1-20: Kerecsend (KevEy 2011);

3/1-50: Zámolyi-medence (KEVEY et al. 2015); 4/1-50: Tolnai-hegyhát (KEVEY et al. 2018);

5/1-40: Harkány-Nagynyárádi-sík (KEVEY 2016)

\section{Karakterfajok aránya}

A zárt lösztölgyesek (Pulmonario mollis-Quercetum roboris) felépítésében a legfontosabbak a száraz tölgyesek elemei (Quercetea pubescentis-petraeae incl. Quercetalia cerridis, Quercion farnetto, Quercion petraeae, Aceri tatarici-Quercion). E Quercetea pubescentis-petraeae elemek 25,95\% csoportrészesedést és 30,58\% csoporttömeget mutatnak (1. és 4. táblázat; 6. ábra). A nyílt lösztölgyesekhez (Aceri tatarici-Quercetum pubescentis-roboris) képest erősen visszaszorulnak a száraz gyepek növényei (Festuco-Bromea s.l. incl. Festuco-Brometea, Festucetalia valesiacae et Festucion rupicolae). Csoportrészesedésük 4,33\%, csoporttömegük pedig mindössze 0,46\% (1. és 4. táblázat; 7. ábra). A mezofil lomberdei növények (Fagetalia) esetében viszont fordított az eset, ugyanis 4,39\% csoportrészesedéssel és 4,18\% csoporttömeggel a zárt lösztölgyesekben jóval gyakoribb értéket érnek el, mint a nyílt lösztölgyesekben (1. és 4. táblázat; 8. ábra). 
Ha az eddig felmért zárt lösztölgyeseket hasonlítjuk össze, akkor azt tapasztaljuk, hogy a karakterfajok aránya tájegységenként bizonyos határok között változik. A Mezőföldön a száraz tölgyesek (Quercetea pubescentis-petraeae) elemei közepes, a száraz gyepek (FestucoBromea s.l.) elemei magas, az üde erdők mezofil elemei (Fagetalia) pedig viszonylag alacsony arányt mutatnak (5. táblázat).
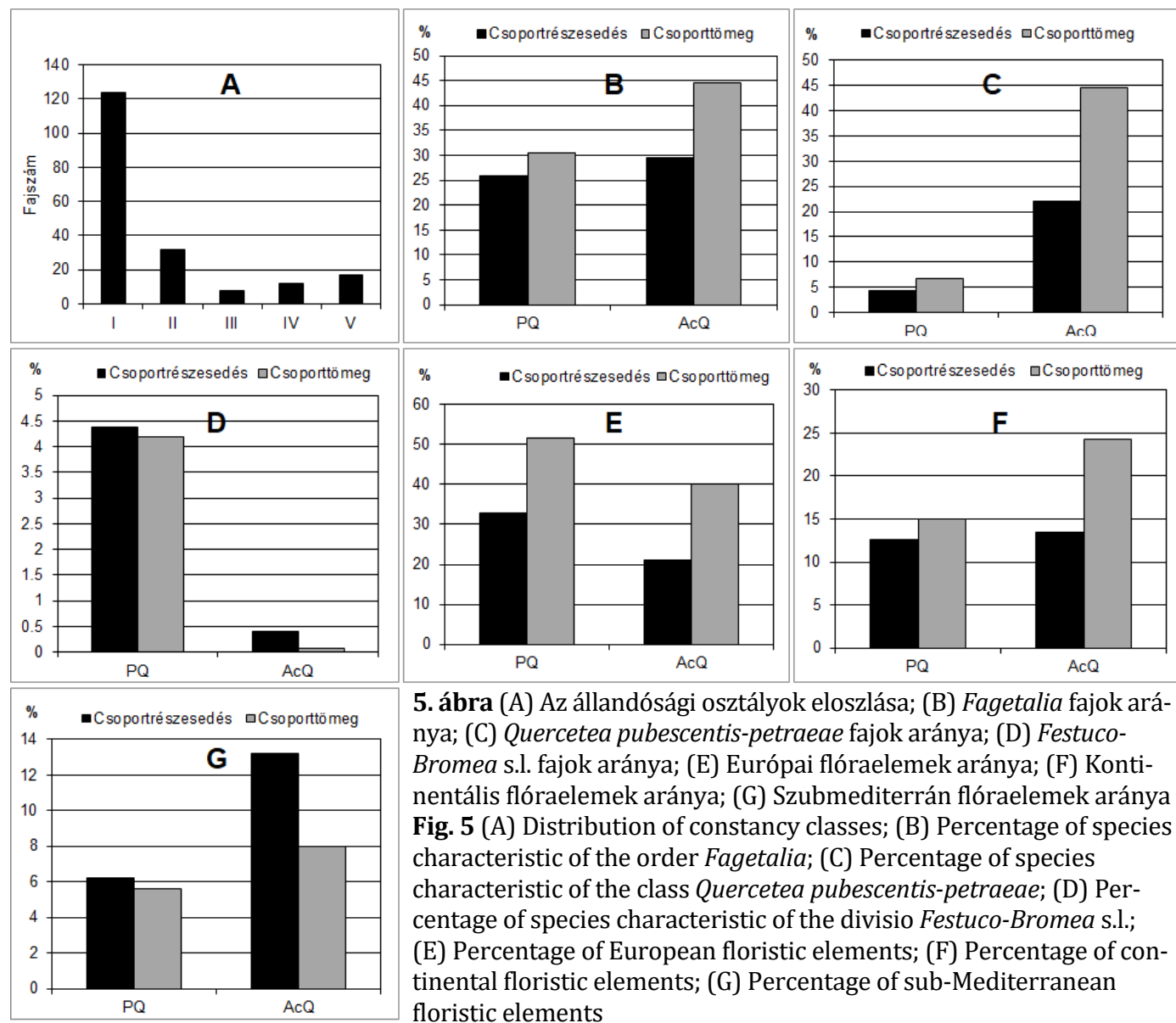

5. ábra (A) Az állandósági osztályok eloszlása; (B) Fagetalia fajok aránya; (C) Quercetea pubescentis-petraeae fajok aránya; (D) FestucoBromea s.l. fajok aránya; (E) Európai flóraelemek aránya; (F) Kontinentális flóraelemek aránya; (G) Szubmediterrán flóraelemek aránya Fig. 5 (A) Distribution of constancy classes; (B) Percentage of species characteristic of the order Fagetalia; (C) Percentage of species characteristic of the class Quercetea pubescentis-petraeae; (D) Percentage of species characteristic of the divisio Festuco-Bromea s.l.; (E) Percentage of European floristic elements; (F) Percentage of continental floristic elements; (G) Percentage of sub-Mediterranean floristic elements

PQ: Pulmonario mollis-Quercetum roboris (Kevey \& Lendvai ined.: 20 felv.)

AcQ: Aceri tatarici-Quercetum pubescentis-roboris (LENDVAI et al. 2014a: 20 felv.)

\section{Flóraelemek aránya}

A flóraelemek kapcsán feltűnő, hogy az európai fajok (incl. közép-európai) a zárt lösztölgyesekben (Pulmonario mollis-Quercetum roboris) jóval gyakoribbak (32,74\% csoportrészesedés, 51,75\% csoporttömeg), mint a nyílt lösztölgyesekben (Aceri tatarici-Quercetum pubescentis-roboris) (6. táblázat; 9. ábra). A kontinentális (incl. szubkontinentális, pontusi stb.) elemek esetében fordított a helyzet. Ezek a zárt lösztölgyesekben (Pulmonario mollisQuercetum roboris) jóval alacsonyabb értéket érnek el (6,21\% csoporttömeg, 5,63\% csoporttömeg), mint a nyílt lösztölgyesekben (Aceri tatarici-Quercetum pubescentis-roboris) (6. táblázat; 10. ábra). Hasonló arányt mutatnak a szubmediterrán (incl. kelet-szubmediterrán, balkáni stb.) elemek is, amelyek a zárt lösztölgyesekben (Pulmonario mollis-Quercetum robo- 
ris) ritkábban (12,57\% csoportrészesedés, 15,04\% csoporttömeg), a nyílt lösztölgyesekben (Aceri tatarici-Quercetum pubescentis-roboris) pedig gyakrabban fordulnak elő (6. táblázat; 11. ábra). Összességében megállapítható, hogy a Mezőföld zárt lösztölgyeseiben (Pulmonario mollis-Quercetum roboris) a szubmediterrán elemek aránya mintegy kétszer akkora, mint a kontinentális elemeké. Mindkét flóraelem azonban a nyílt lösztölgyesekben (Aceri tatariciQuercetum pubescentis-roboris) éri el a magasabb értéket.

Ha összehasonlítjuk a magyarországi zárt lösztölgyesek flóraelemeinek arányát, viszonylag szűkebb határok közötti változó értékeket kapunk. Ezek közül kiemelendő, hogy az európai elemek csoportrészesedése, valamint a szubmediterrán elemek csoportrészesedése és csoporttömege a Mezőföldön legkisebb. Ezen kívül a kontinentális elemek a HarkányNagynyárádi-síkon mutatják a legalacsonyabb értéket (7. táblázat).

\section{Természetvédelmi vonatkozások}

A 20 cönológiai felvétel alapján e zárt lösztölgyesekből 12 védett növényfaj került elő, valamennyi akcidens (K I) előfordulással: K I: Ajuga laxmannii, Dictamnus albus, Doronicum hungaricum, Galanthus nivalis, Iris variegata, Lonicera caprifolium, Orchis purpurea, Phlomis tuberosa, Ranunculus illyricus, Thalictrum aquilegiifolium, Scilla vindobonensis, Vinca herbacea.

A dendrológiai értékek közé tartoznak egyes famatuzsálemek, mint amilyeneket a Lajoskomárom melletti Újmajor erdeiben láttunk (1. táblázat: 7. felvétel). Itt a Quercus pubescens egyedek törzsátmérője kb. $1 \mathrm{~m}$-nek bizonyult. Ugyanitt $80 \mathrm{~cm}$ átmérőjű Morus alba is van. Ez az erdőrészt egykor legelőerdőként használhatták.

Sajnos jövevény fajok is szerepelnek a felvételekben: K IV: Celtis occidentalis*, Robinia pseudo-acacia*. - K II: Ailanthus altissima*, Morus alba. - K I: Acer negundo*, Aesculus hippocastanum, Aster $\times$ salignus*, Stenactis annua, Gleditsia triacanthos, Juglans regia, Laburnum anagyroides, Parthenocissus inserta*, Phytolacca americana*, Solidago gigantea*, Syringa vulgaris, Vitis vulpina*. Különösen a *-gal jelölt fajok fejthetnek ki jelentősebb flóraszennyező hatást, amelyre elsősorban egy esetleges tarvágás után lehet számítani.

A vizsgált zárt lösztölgyesek (Pulmonario mollis-Quercetum roboris) állapota - kissé leszegényedett faji összetételük ellenére - igen jónak mondható. Az Alföld ősi vegetációjának igen értékes fragmentumait képezik, ezért fokozott védelmet érdemelnének. Megőrzésük, rekonstrukciójuk természetvédelmünk fontos feladata.

\section{Megvitatás}

A Mezőföld zárt lösztölgyesei (Pulmonario mollis-Quercetum roboris) csak parányi fragmentumokban érték meg a jelenkort. Egyes állományokat az egykori nagybirtoki kastély-parkok őrizték meg (Dég, Előszállás). E fragmentálódott és izolálódott társulás-töredékeket az utóbbi évszázadokban számos környezeti hatás érhette, mint az erdőirtások, az erdőgazdálkodás, a legeltetés, a szántóföldi növénytermesztés stb. Ennek következtében faji összetételük bizonnyal szegényedett, gyomosodott, inváziós fajok által degradálódott stb. E zárt lösztölgyesek (Pulmonario mollis-Quercetum roboris) mindenütt a száraz talajú nyílt lösztölgyesek (Aceri tatarici-Quercetum pubescentis-roboris) és az üde termőhelyű gyertyános-tölgyesek (Corydali cavae-Carpinetum) között képeznek átmenetet.

A készített cönológiai felvételek sokváltozós elemzése (1-4. ábra) a fentiek ellenére azt bizonyítja, hogy a felmért állományok még most is természetközeli állapotúak, faji összetételük igen hasonlít az ország egyéb részein (Kerecsend, Zámolyi-medence, Tolnai-hegyhát, 
Harkány-Nagynyárádi-sík) felmért zárt lösztölgyesekéhez. A Mezőföld nyílt és zárt lösztölgyesei ugyan az első próbálkozáskor nem váltak el egyértelműen, de miután a húsz nyílt lösztölgyes felvételből (LENDVAI et al. 2014a) eltávolítottunk öt átmeneti jellegű felvételt, a két asszociáció szépen elkülönült. Az eltávolított öt mintaterület már a cönológiai felvételkészítés alatt is átmenetinek tűnt, mert bennük lombkoronájuk jóval zártabb, továbbá gyepszintjükben a száraz gyepek elemei (Festuco-Brometea, Festucetalia valesiacae, Festucion rupicolae) alig vannak képviselve.

A zárt és a nyílt lösztölgyesek a hagyományos statisztikai számítások (karakterfajok és flóraelemek aránya) révén is szépen elkülönültek. A karakterfajok és a flóraelemek aránya kisebb eltérésektől eltekintve - hasonlóan alakult, mint a Kerecsendi-erdő (KEvEY 2011), a Zámolyi-medence (KeveY et al. 2015), a Harkány-Nagynyárádi-sík (KeveY 2016) és a Tolnaihegyhát (Kevey et al. 2018) zárt lösztölgyeseiben (Pulmonario mollis-Quercetum roboris). Ezzel megerősítést nyert az, hogy hasonló termőhely esetén az asszociáció állományai egymástól távol is kialakulhatnak. Az eredmények azt is bizonyítják, hogy a vizsgált zárt lösztölgyesek (Mezőföld, Tolnai-hegyhát, Harkány-Nagynyárádi-sík, Zámolyi-medence, Kerecsend) egy asszociációhoz tartoznak, amelynek helye a növénytársulások rendszerében az alábbi módon vázolható:

Divízió: Querco-Fagea Jakucs 1967

Osztály: Querco-Fagetea Br.-Bl. et Vlieger in Vlieger 1937 em. Borhidi in Borhidi et Kevey 1996

Rend: Quercetalia cerridis Borhidi in Borhidi et Kevey 1996

Csoport: Aceri tatarici-Quercion Zólyomi et Jakucs 1957

Alcsoport: Polygonato latifolio-Quercenion roboris Kevey 2008

Társulás: Pulmonario mollis-Quercetum roboris Kevey 2008

A társulás diagnosztikus fajkombinációját nehéz megadni. A mezőföldi állományokból 34 meghatározó fajt érdemes kiemelni. Közülük csak az Euonymus verrucosus, a Polygonatum latifolium, a Viburnum lantana és a Viola hirta sorolható az állandó (K IV-V) elemek közé. Nagyobb számmal vannak a járulékos (K II-III) fajok: Anemone ranunculoides, Berberis vulgaris, Brachypodium pinnatum, Campanula bononiensis, Carex michelii, Corydalis pumila, Euphorbia epithymoides, Myosotis sparsiflora, Pulmonaria mollis, Quercus pubescens, Quercus robur, Thalictrum aquilegiifolium, Veratrum nigrum, Vinca minor. Végül legnagyobb számmal a véletlen előfordulású (K I) elemek vannak képviselve: Acer tataricum, Anthericum ramosum, Arum orientale, Asparagus officinalis, Buglossoides purpuro-coerulea, Cornus mas, Convallaria majalis, Corydalis cava, Dictamnus albus, Doronicum hungaricum, Gagea lutea, Galanthus nivalis, Iris variegata, Polygonatum odoratum, Phlomis tuberosa, Scilla vindobonensis.

Uralkodó, vagy domináns fajok (A-D 4) főleg a lombkoronaszintben (Acer campestre, Fraxinus excelsior, Fraxinus ornus, Quercus robur), ritkán a cserjeszintben (Crataegus monogyna), vagy a gyepszintben (Polygonatum latifolium) találhatók. A Quercus pubescens az Acer campestre-vel, vagy az Ulmus minor-ral több helyen kodomináns szerepet tölt be.

Elsősorban a társulás osztályokat (Querco-Fagetea, Quercetea pubescentis-petraeae) képviselik nagyobb számú karakterfajok. A fent felsorolt fontosabb fajok jelentős része többékevésbé a Fagetalia rendet képviseli, de ezek állandósága alacsony (K I-II): Anemone ranunculoides, Arum orientale, Corydalis cava, Corydalis pumila, Galanthus nivalis, Myosotis sparsiflora, Scilla vindobonensis, Ulmus glabra, Vinca minor. Jelentősek még a Quercetalia cerridis rend (incl. Quercion petraeae et Aceri tatarici-Quercion) elemei, de ezek mind kísérő fajok (K I): Acer tataricum, Ajuga laxmannii, Festuca heterophylla, Phlomis tuberosa.

A zárt és nyílt lösztölgyesek közötti különbséget a differenciális fajok is jelzik. A Kerecsendi-erdőben 25 (KEVEY 2011), a Zámolyi-medencében 29 (KeVEY et al. 2015), a Tolnaihegyháton pedig 31 (KEVEY et al. 2018) olyan növényfajt sikerült kimutatni, amelyek a zárt 
lösztölgyeseket (Pulmonario mollis-Quercetum roboris) megkülönböztetik a nyílt lösztölgyesektől (Aceri tatarici-Quercetum pubescentis-roboris). Az ilyen növények száma a Mezőföldön azonban igen alacsony ( 8 faj), ezért a nyílt lösztölgyesektől való különbséget nagyobbrészt egyes fajok (67 faj) hiánya bizonyítja (8. táblázat).

Fent láttuk, hogy a Mezőföld zárt lösztölgyesei (Pulmonario mollis-Quercetum roboris) ugyan rendelkeznek az ősi viszonyokra jellemző fajkészlettel, de ugyanakkor az elszegényedés jeleit is mutatják. Ennek oka a fragmentáció, az izoláció és a tájhasználat lehet. Viszonylag legjobb, leginkább természetszerűbb állapotban a Mezőszilas és Lajoskomárom környéki állományok vannak (1. táblázat: 1-8. felvétel). A Mezőföld e részén maradtak meg legjobban az ősi erdők fragmentumai, amelyek faji összetétele legjobban hasonlít az erdőtársulás Tolnai-hegyháton (KevEY et al. 2018) és a Zámolyi-medencében (KeVEY et al. 2015) levő fajgazdag állományaira.

\section{Köszönetnyilvánítás}

Köszönetünket fejezzük ki Fekete Gábor† akadémikus úrnak hasznos tanácsaiért, valamint Bölöni János lektornak a javító szándékú észrevételeiért.

\section{Irodalom}

BECKING R. W. (1957): The Zürich-Montpellier School of phytosociology. - Botanical Review 23: 411-488.

Borhidi A. (1961): Klimadiagramme und klimazonale Karte Ungarns. - Annales Universitatis Scientiarum Budapestinensis, Sectio Biologica 4: 21-250.

Borhidi A. (1993): A magyar flóra szociális magatartás típusai, természetességi és relatív ökológiai értékszámai. - Janus Pannonius Tudományegyetem, Pécs, 95 pp.

BoRHIDI A. (1995): Social behaviour types, the naturalness and relative ecological indicator values of the higher plants in the hungarian flora. - Acta Botanica Academiae Scientiarum Hungaricae 39: 97-181.

BoRHIDI A. \& KeVEy B. (1996): An annotated checklist of the hungarian plant communities II. - In: BoRHIDI A. (ed.), Critical revision of the hungarian plant communities. Janus Pannonius University, Pécs, pp. 95-138.

Borhidi A., Kevey B. \& Lendvai G. (2012): Plant communities of Hungary. - Akadémiai Kiadó, Budapest, $544 \mathrm{pp}$.

BRAun-Blanquet J. (1964): Pflanzensoziologie (ed. 3.). - Springer Verlag, Wien-New York, 865 pp.

Horváth A., Kevey B., Lendvai G., Simon Gy. \& Sonnevend I. (2017): Tatárjuharos-tölgyesek (Aceri tatariciQuercetum pubescentis-roboris ZóLYOMI 1957) az Észak-Mezőföldön és a Zámolyi-medence környékén. - Botanikai Közlemények 104(1): 109-130.

Horváth F., Dobolyi Z. K., MorschHaUSER T., LőKÖS L., KARAS L. \& SZERDAhelYI T. (1995): Flóra adatbázis 1.2. - MTA Ökológiai és Botanikai Kutatóintézete, Vácrátót, 267 pp.

JAKUCS P. (1967): Gedanken zur höheren Systematik der europäischen Laubwälder. - Contribuţii Botanice, Cluj 1967: 159-166.

KeveY B. (2008): Magyarország erdőtársulásai (Forest associations of Hungary). Die Wälder von Ungarn. - Tilia 14: 1-488. + CD-adatbázis (244 ábra + 230 táblázat).

KeveY B. (2011): Zárt lösztölgyesek a Kerecsendi-erdőben (Pulmonario mollis-Quercetum roboris KeVEY 2008). - Botanikai Közlemények 98(1-2): 79-116.

Kevey B. (2016): A Harkány-Nagynyárádi-sík zárt lösztölgyesei. - Kaposvári Rippl-Rónai Múzeum Közleményei 4: 31-56.

KEVEY B. \& HiRMANN A. (2002): „NS” számítógépes cönológiai programcsomag. - In: Aktuális flóra- és vegetációkutatások a Kárpát-medencében V. Pécs, 2002. március 8-10. (Összefoglalók), pp. 74.

Kevey B., Horváth A., Lendvai G., Simon Gy. \& Sonnevend I. (2015): A Zámolyi-medence és környékének zárt lösztölgyesei (Pulmonario mollis-Quercetum roboris KeveY 2008). - Botanikai Közlemények 102(1-2): 85-129. 
Kevey B., Horváth A., Lendvai G. \& Simon Gy. (2018): A Tolnai-hegyhát zárt lösztölgyesei (Pulmonario mollis-Quercetum roboris KEVEY 2008). - Botanikai Közlemények 105(2): 269-284. + Elektronikus mellékletek (E1-E5 táblázat).

KIRÁLY G. (szerk.) (2009): Új magyar füvészkönyv. Magyarország hajtásos növényei. Határozókulcsok. Aggteleki Nemzeti Park Igazgatóság, Jósvafő, 616 pp.

Lendvai G., HoRváth A. \& KeVEy B. (2014a): Tatárjuharos tölgyesek (Aceri tatarici-Quercetum pubescentis-roboris ZóLYomi 1957) a Mezőföldön. - Botanikai Közlemények 101(1-2): 145-187.

LendVAi G., Kevey B. \& HoRváth A. (2014b): A Velencei-hegység tatárjuharos tölgyesei (Aceri tatariciQuercetum pubescentis-roboris Zólyomi 1957). - Botanikai Közlemények 101(1-2): 189-226.

Mucina L., Grabherr G. \& WALlNöFER S. (1993): Die Pflanzengesellschaften Österreichs III. Wälder und Gebüsche. - Gustav Fischer, Jena-Stuttgart-New York, 353 pp.

OBERDORFER E. (1992): Süddeutsche Pflanzengesellschaften IV. A. Textband. - Gustav Fischer Verlag, JenaStuttgart-New York, $282 \mathrm{pp}$.

PodANi J. (2001): SYN-TAX 2000 Computer Programs for Data Analysis in Ecologi and Systematics. Scientia, Budapest, $53 \mathrm{pp}$.

Purger D., Lengyel A., Kevey B., Lendvai G., Horváth A., Tomić Z. \& Csiky J. (2014): Numerical classification of oak forests on loess in Hungary, Croatia and Serbia. - Preslia 86: 47-66.

Soó R. (1964, 1966, 1968, 1970, 1973, 1980): A magyar flóra és vegetáció rendszertani-növényföldrajzi kézikönyve I-VI. - Akadémiai kiadó, Budapest.

VLIEGER J. (1937): Aperçu sur les unités phytosociologiques supérieures des Pays-Bas. - Nederlandsh Kruidkundig Archief 47: 335.

ZólYomi B. \& JAKUCS P. (1957): Neue Einteilung der Assoziationen der Quercetalia pubescentis-petraeaeOrdnung im pannonischen Eichenwaldgebiet. - Annales Historico-Naturales Musei Nationalis Hungarici 8: 227-229.

Beérkezett / received: 2019. 01. 20. • Elfogadva / accepted: 2019. 03. 26.

Rövidítések

A1: felső lombkoronaszint; A2: alsó lombkoronaszint; Adv: Adventiva; AF: Aremonio-Fagion; Ai: Alnion incanae; Aph: Aphanion; AQ: Aceri tatarici-Quercion; AR: Agropyro-Rumicion crispi; Ara: Arrhenatheretalia; Arc: Arction lappae; ArK: Artemisio-Kochion; Arn: Arrhenatherion elatioris; Ata: Alnetalia glutinosae; B1: cserjeszint; B2: újulat; Bia: Bidentetalia; C: gyepszint; Cau: Caucalidion platycarpos; Che: Chenopodietea; ChS: Chenopodio-Scleranthea; Cia: Calystegietalia sepium; Cn: Calystegion sepium; Cp: Carpinenion betuli; CyF: Cynodonto-Festucenion; Epa: Epilobietalia; F: Fagetalia sylvaticae; FB: Festuco-Bromea; FBt: Festuco-Brometea; FiC: Filipendulo-Cirsion oleracei; FPe: Festuco-Puccinellietea; FPi: Festuco-Puccinellietalia; Fru: Festucion rupicolae; Fvg: Festucion vaginatae; Fvl: Festucetalia valesiacae; GA: Galio-Alliarion; I: Indifferens; incl.: inclusive (beleértve); ined: ineditum (kiadatlan közlés); Mag: Magnocaricion; Moa: Molinietalia coeruleae; MoA: MolinioArrhenatherea; Moa: Molinio-Juncetea; NA: Nardo-Agrostion tenuis; OCn: Orno-Cotinion; Ona: Onopordetalia; Onn: Onopordion acanthii; Pla: Plantaginetalia majoris; Pna: Populenion nigro-albae; PQ: Pino-Quercion; Prf: Prunion fruticosae; Pru: Prunetalia spinosae; Pte: Phragmitetea; Qc: Quercetalia cerridis; Qfa: Quercion farnetto; QFt: Querco-Fagetea; Qp: Quercion petraeae; Qpp: Quercetea pubescentis-petraeae; Qr: Quercetalia roboris; Qrp: Quercion robori-petraeae; S: summa (összeg); Sal: Salicion albae; SaS: Sambuco-Salicion capreae; Sea: Secalietea; Sio: Sisymbrion officinalis; s.l.: sensu lato (tágabb értelemben); Spu: Salicetalia purpureae; TA: Tilio platyphyllae-Acerenion pseudoplatani; Ulm: Ulmenion; VP: Vaccinio-Piceetea. 
KEVEY et al. (2019): Zárt lösztölgyes maradványok a Mezőföldön

1. táblázat Pulmonario mollis-Quercetum roboris felvételek, Mezőföld Table 1 Pulmonario mollis-Quercetum roboris relevés, Mezőföld

\begin{tabular}{|c|c|c|c|c|c|c|c|c|c|c|c|c|c|c|c|c|c|c|c|c|c|c|c|c|}
\hline & & 1 & 2 & 3 & 4 & 5 & 6 & 7 & 8 & 9 & $\begin{array}{l}\mathbf{1} \\
\mathbf{0}\end{array}$ & $\begin{array}{l}1 \\
1\end{array}$ & $\begin{array}{l}1 \\
2\end{array}$ & $\begin{array}{l}1 \\
3 \\
\end{array}$ & $\begin{array}{l}1 \\
4 \\
\end{array}$ & $\begin{array}{l}\mathbf{1} \\
\mathbf{5}\end{array}$ & $\begin{array}{l}1 \\
6 \\
\end{array}$ & & $\begin{array}{l}1 \\
8 \\
\end{array}$ & & $\begin{array}{l}2 \\
0 \\
\end{array}$ & A-D & $\mathbf{K}$ & K\% \\
\hline \multicolumn{25}{|l|}{$\begin{array}{l}\text { 1. Querco-Fagea } \\
\text { 1.1. Salicetea purpureae } \\
\text { 1.1.1. Salicetalia purpureae } \\
\text { 1.1.1.1. Salicion albae }\end{array}$} \\
\hline Cucubalus baccifer (Cn, Ulm) & $\mathrm{C}$ & - & - & + & - & - & - & - & - & - & - & - & - & - & - & + & - & - & - & - & - & + & I & 10 \\
\hline \multirow[t]{3}{*}{ Humulus lupulus (Cn, Ata, Ai) } & B1 & - & - & - & - & - & - & - & - & - & - & - & - & - & - & + & - & - & - & - & - & + & I & 5 \\
\hline & $\mathrm{C}$ & - & - & - & - & - & - & - & - & - & - & - & - & - & - & + & - & - & - & + & - - & + & I & 10 \\
\hline & $\mathrm{S}$ & - & - & - & - & - & - & - & - & - & - & - & - & - & - & + & - & - & - & + & - & + & I & 10 \\
\hline \multicolumn{25}{|l|}{ 1.2. Querco-Fagetea } \\
\hline \multirow[t]{4}{*}{ Crataegus monogyna (Qpp) } & A2 & 1 & - & - & - & - & - & - & - & - & - & - & - & - & - & 2 & - & - & - & - & - & $1-2$ & I & 10 \\
\hline & B1 & 2 & 2 & 2 & 4 & 3 & 3 & 2 & 1 & 2 & + & - & 2 & 2 & 3 & 3 & 3 & 2 & 1 & 1 & 1 & +-4 & $\mathrm{~V}$ & 95 \\
\hline & B2 & + & + & + & + & + & - & - & - & + & + & + & + & + & + & - & + & + & + & - & + & + & IV & 75 \\
\hline & $\mathrm{S}$ & 2 & 2 & 2 & 4 & 3 & 3 & 2 & 1 & 2 & + & + & 2 & 2 & 3 & 4 & 3 & 2 & 1 & 1 & 1 & +-4 & $\mathrm{~V}$ & 100 \\
\hline \multirow[t]{4}{*}{ Euonymus europaeus (Qpp) } & A2 & - & - & - & - & - & - & - & - & - & - & - & - & - & - & - & + & - & - & - & - & + & I & 5 \\
\hline & B1 & - & + & - & - & - & + & + & + & 1 & - & - & - & - & + & + & - & - & + & 1 & + & +-1 & III & 50 \\
\hline & B2 & + & + & + & + & + & + & + & + & 1 & + & + & + & + & + & + & + & + & + & + & + & +-1 & $\mathrm{~V}$ & 100 \\
\hline & $\mathrm{S}$ & + & + & + & + & + & + & + & + & 2 & + & + & + & + & + & + & + & + & + & 1 & + & +-2 & $\mathrm{~V}$ & 100 \\
\hline Geum urbanum (Epa, Cp, Qpp) & $\mathrm{C}$ & + & 1 & + & + & + & + & + & + & 1 & + & + & + & 1 & + & + & + & + & 1 & + & + & +-1 & $\mathrm{~V}$ & 100 \\
\hline \multirow{5}{*}{ Ulmus minor (Ai, Ulm, Qpp) } & A1 & - & 3 & 3 & - & - & - & - & 1 & - & 1 & 2 & - & - & - & - & 2 & - & - & - & - & $1-3$ & II & 30 \\
\hline & A2 & 1 & 2 & 2 & 3 & 2 & 2 & 3 & 3 & 2 & 2 & 3 & 1 & + & 3 & 2 & 3 & 2 & - & 1 & 2 & +-3 & $\mathrm{~V}$ & 95 \\
\hline & B1 & 1 & 2 & 2 & 1 & 2 & 2 & 3 & 1 & + & 1 & 3 & 1 & 1 & 1 & - & 2 & 1 & + & 1 & 2 & +-3 & $\mathrm{~V}$ & 95 \\
\hline & B2 & + & 1 & 1 & + & + & + & 1 & + & + & + & 1 & + & + & + & + & 1 & + & + & + & + & +-1 & $\mathrm{~V}$ & 100 \\
\hline & $\mathrm{S}$ & 2 & 4 & 4 & 3 & 3 & 3 & 5 & 3 & 2 & 2 & 5 & 2 & 1 & 3 & 2 & 4 & 2 & + & 2 & 3 & +-5 & $\mathrm{~V}$ & 100 \\
\hline \multirow[t]{3}{*}{ Fallopia dumetorum (Qpp, GA) } & B1 & - & - & - & - & - & - & - & - & - & - & - & - & - & - & - & - & - & - & + & - & + & I & 5 \\
\hline & $\mathrm{C}$ & + & + & + & + & + & + & + & + & + & + & + & 1 & 1 & + & - & + & + & + & + & + & +-1 & $\mathrm{~V}$ & 95 \\
\hline & $\mathrm{S}$ & + & + & + & + & + & + & + & + & + & + & + & 1 & 1 & + & - & + & + & + & + & + & +-1 & $\mathrm{~V}$ & 95 \\
\hline Veronica sublobata & $\mathrm{C}$ & + & + & - & 2 & 2 & 2 & + & 2 & + & 1 & 2 & 2 & 2 & 1 & + & + & + & 1 & 2 & + & +-2 & $\mathrm{~V}$ & 95 \\
\hline Viola suavis s.l. (Qpp) & $\mathrm{C}$ & 1 & 2 & 2 & + & - & + & + & 1 & 2 & 1 & 2 & 1 & 2 & 2 & 2 & 1 & 3 & 2 & 1 & 1 & +-3 & $\mathrm{~V}$ & 95 \\
\hline Brachypodium sylvaticum (Qpp) & $\mathrm{C}$ & + & + & + & + & + & + & + & + & - & 1 & 2 & + & + & + & + & + & 1 & 1 & - & + & +-2 & $\mathrm{~V}$ & 90 \\
\hline Polygonatum latifolium (Qpp) & $\mathrm{C}$ & + & 2 & + & 2 & 2 & 1 & 1 & 1 & 2 & 4 & 3 & + & - & 1 & 1 & + & 2 & - & 3 & 2 & +-4 & $\mathrm{~V}$ & 90 \\
\hline Lapsana communis (Qpp, GA, Epa) & $\mathrm{C}$ & + & + & + & + & - & - & + & + & - & + & + & + & + & + & + & + & + & + & + & + & + & $\mathrm{V}$ & 85 \\
\hline \multirow[t]{3}{*}{ Ligustrum vulgare (Cp, Qpp) } & B1 & - & + & 1 & + & - & - & + & - & - & - & 1 & 1 & + & + & - & + & 1 & + & - & 1 & +-1 & III & 60 \\
\hline & B2 & 1 & + & + & + & - & + & + & - & + & - & + & + & - & + & + & + & + & + & - & + & +-1 & IV & 75 \\
\hline & $\mathrm{S}$ & 1 & + & 1 & + & - & + & + & - & + & - & 1 & 1 & + & + & + & + & 1 & + & - & 1 & +-1 & IV & 80 \\
\hline \multirow[t]{4}{*}{ Rhamnus catharticus (Qpp, Pru) } & A2 & + & + & - & - & - & + & - & - & - & - & - & - & - & + & + & 2 & 1 & - & - & - & +-2 & II & 35 \\
\hline & B1 & + & + & + & + & - & - & - & - & 3 & - & - & + & - & + & - & 2 & 2 & - & + & -1 & +-3 & III & 55 \\
\hline & B2 & - & - & + & + & - & + & + & - & + & - & - & + & + & + & - & - & - & + & + & + & + & III & 55 \\
\hline & $\mathrm{S}$ & + & + & + & + & - & + & + & - & 3 & - & - & + & + & 1 & + & 3 & 2 & + & + & 1 & +-3 & IV & 80 \\
\hline \multirow[t]{5}{*}{ Acer campestre (Qpp) } & A1 & - & 3 & - & 2 & 2 & 3 & 3 & 4 & - & 1 & - & - & - & - & - & - & 3 & - & 1 & 1 & $1-4$ & III & 50 \\
\hline & A2 & - & 2 & - & 1 & 3 & 2 & 2 & 2 & - & 1 & - & - & - & - & - & - & + & - & 1 & 2 & +-3 & III & 50 \\
\hline & B1 & - & - & + & 1 & 1 & 1 & 2 & 2 & - & + & - & - & - & - & - & - & - & - & - & 2 & +-2 & II & 40 \\
\hline & B2 & - & + & - & + & + & - & + & + & - & + & - & + & + & - & + & + & + & - & + & + & + & IV & 65 \\
\hline & $\mathrm{S}$ & - & 4 & + & 2 & 4 & 4 & 4 & 5 & - & 2 & - & + & + & - & + & + & 3 & - & 2 & 3 & +-5 & IV & 75 \\
\hline Geranium robertianum (Epa) & $\mathrm{C}$ & + & - & 1 & + & + & 1 & 1 & + & - & + & + & - & - & 2 & 3 & 2 & 2 & 1 & - & + & +-3 & IV & 75 \\
\hline Dactylis polygama (Qpp, Cp) & $\mathrm{C}$ & - & - & - & + & + & - & - & + & - & + & + & + & + & + & + & + & + & + & + & - & + & IV & 65 \\
\hline Ranunculus ficaria & $\mathrm{C}$ & 2 & - & 1 & 1 & 2 & - & + & + & 2 & 3 & 3 & - & - & - & - & - & 1 & 1 & 3 & 1 & +-3 & IV & 65 \\
\hline \multirow[t]{4}{*}{ Quercus robur (Ai, Cp, Qpp) } & A1 & 2 & - & - & - & - & - & - & - & 4 & 1 & - & 4 & 2 & 4 & 4 & 1 & 2 & 1 & 1 & 2 & $1-4$ & III & 60 \\
\hline & A2 & - & - & - & - & - & - & - & - & - & + & - & - & - & - & - & 1 & + & - & - & - & +-1 & I & 15 \\
\hline & B2 & + & - & - & - & - & - & - & - & + & + & - & + & + & + & - & - & - & - & - & - & + & II & 30 \\
\hline & $\mathrm{S}$ & 2 & - & - & - & - & - & - & - & 4 & 1 & - & 4 & 2 & 4 & 4 & 2 & 2 & 1 & 1 & 2 & $1-4$ & III & 60 \\
\hline Campanula persicifolia (Qpp) & $\mathrm{C}$ & + & + & - & + & - & + & - & + & - & + & + & - & - & + & + & + & - & + & - & - & + & III & 55 \\
\hline Poa nemoralis (Qpp) & $\mathrm{C}$ & - & - & - & + & - & - & - & + & - & 1 & 1 & + & + & + & + & + & 2 & - & - & + & +-2 & III & 55 \\
\hline
\end{tabular}


Kitaibelia 24(1): 66-93.

\begin{tabular}{|c|c|c|c|c|c|c|c|c|c|c|c|c|c|c|c|c|c|c|c|c|c|c|c|c|}
\hline & & 1 & 2 & 3 & 4 & 5 & 6 & 7 & 8 & 9 & $\begin{array}{l}1 \\
\mathbf{0}\end{array}$ & $\begin{array}{l}1 \\
1\end{array}$ & $\begin{array}{l}1 \\
2\end{array}$ & $\begin{array}{l}1 \\
3\end{array}$ & $\begin{array}{l}1 \\
4\end{array}$ & $\begin{array}{l}1 \\
5\end{array}$ & $\begin{array}{l}1 \\
6\end{array}$ & $\begin{array}{l}1 \\
7\end{array}$ & $\begin{array}{l}1 \\
\mathbf{8}\end{array}$ & $\begin{array}{l}1 \\
9\end{array}$ & $\begin{array}{l}2 \\
\mathbf{0}\end{array}$ & A-D & $\mathbf{K}$ & К\% \\
\hline \multirow[t]{4}{*}{ Clematis vitalba (Qpp) } & A2 & - & - & - & - & - & - & + & - & - & - & - & - & - & - & - & - & + & - & - & - & + & I & 10 \\
\hline & B1 & - & - & - & + & - & - & - & - & - & - & - & - & - & - & - & - & - & - & - & - & + & I & 5 \\
\hline & B2 & + & - & - & + & - & + & + & - & - & - & - & - & - & + & - & + & + & + & - & - & + & II & 40 \\
\hline & S & + & - & - & + & - & + & + & - & - & - & - & - & - & + & - & + & + & + & - & - & + & II & 40 \\
\hline \multirow[t]{3}{*}{ Cornus sanguinea (Qpp) } & B1 & - & - & + & - & 1 & - & - & - & - & - & - & - & - & - & - & - & + & - & 1 & 1 & +-1 & II & 25 \\
\hline & B2 & - & - & + & - & - & - & - & - & - & - & - & - & - & - & - & - & + & + & + & + & + & II & 25 \\
\hline & $\mathrm{S}$ & - & - & + & - & 1 & - & - & - & - & - & - & - & - & - & - & - & + & + & 1 & 1 & +-1 & II & 30 \\
\hline \multirow[t]{5}{*}{ Fraxinus excelsior (Qpp, TA) } & A1 & - & - & - & - & - & - & - & - & 1 & 4 & 3 & - & - & - & - & - & - & 3 & 3 & 1 & $1-4$ & II & 30 \\
\hline & A2 & - & - & - & - & - & - & - & - & 2 & - & 1 & - & - & - & - & - & - & 2 & 2 & + & +-2 & II & 25 \\
\hline & B1 & - & - & - & - & - & - & - & - & 1 & - & - & - & - & - & - & - & - & + & 2 & - & +-2 & I & 15 \\
\hline & B2 & - & - & - & - & - & - & - & - & + & + & 1 & - & - & - & - & - & - & + & + & + & +-1 & II & 30 \\
\hline & $\mathrm{S}$ & - & - & - & - & - & - & - & - & 2 & 4 & 3 & - & - & - & - & - & - & 4 & 4 & 1 & $1-4$ & II & 30 \\
\hline Carex divulsa & $\mathrm{C}$ & - & - & - & + & - & + & - & + & - & - & - & - & + & - & - & - & - & - & + & - & + & II & 25 \\
\hline Carex spicata (Qpp, Epa) & $\mathrm{C}$ & + & - & - & - & - & - & - & - & - & - & - & - & - & + & + & - & + & + & - & - & + & II & 25 \\
\hline Heracleum sphondylium (Qpp, MoA) & $\mathrm{C}$ & - & + & + & - & + & - & + & + & - & - & - & - & - & - & - & - & - & - & - & - & + & II & 25 \\
\hline Mycelis muralis & $\mathrm{C}$ & - & - & - & - & - & - & - & - & - & - & - & - & - & + & + & + & + & - & - & + & + & II & 25 \\
\hline Veratrum nigrum (Qpp) & $\mathrm{C}$ & - & + & - & 1 & 1 & 2 & 1 & - & - & - & - & - & - & - & - & - & - & - & - & - & +-2 & II & 25 \\
\hline Convallaria majalis (Qpp) & $\mathrm{C}$ & - & - & - & - & - & - & - & - & - & - & - & - & - & - & - & - & - & - & + & + & + & I & 10 \\
\hline Fragaria vesca (Qpp, Epa) & $\mathrm{C}$ & - & + & - & - & + & - & - & - & - & - & - & - & - & - & - & - & - & - & - & - & + & I & 10 \\
\hline \multirow[t]{4}{*}{ Tilia cordata (Cp, Qpp) } & $\mathrm{A} 1$ & - & - & - & - & - & - & - & - & - & - & - & - & - & - & - & - & - & - & + & - & + & I & 5 \\
\hline & A2 & - & - & - & - & - & - & - & - & - & - & - & - & - & - & - & - & - & - & - & + & + & I & 5 \\
\hline & B1 & - & - & - & - & - & - & - & - & - & - & - & - & - & - & - & - & - & - & + & - & + & I & 5 \\
\hline & $\mathrm{S}$ & - & - & - & - & - & - & - & - & - & - & - & - & - & - & - & - & - & - & + & + & + & I & 10 \\
\hline Veronica chamaedrys (Qpp, Ara) & $\mathrm{C}$ & + & - & - & - & - & - & + & - & - & - & - & - & - & - & - & - & - & - & - & - & + & I & 10 \\
\hline Corylus avellana (Qpp) & B1 & - & - & - & - & - & - & - & - & - & - & - & - & - & - & - & - & - & - & - & 2 & 2 & I & 5 \\
\hline Lonicera xylosteum (Qpp) & B1 & - & - & - & - & - & - & - & - & - & - & - & - & - & - & - & - & - & - & - & + & + & I & 5 \\
\hline Loranthus europaeus & $\mathrm{A} 1$ & + & - & - & - & - & - & - & - & - & - & - & - & - & - & - & - & - & - & - & - & + & I & 5 \\
\hline Staphylea pinnata (Cp, TA) & B1 & - & - & - & - & - & - & - & - & - & - & - & - & - & - & - & - & - & - & - & + & + & I & 5 \\
\hline \multicolumn{25}{|l|}{ 1.2.1. Fagetalia sylvaticae } \\
\hline Corydalis pumila (Cp, Qpp) & $\mathrm{C}$ & + & 1 & + & 1 & 1 & - & - & 2 & - & - & - & - & - & - & - & - & - & - & 1 & - & +-2 & II & 35 \\
\hline Moehringia trinervia & $\mathrm{C}$ & - & + & + & - & - & - & - & + & - & + & - & - & - & - & + & - & + & - & - & + & + & II & 35 \\
\hline \multirow[t]{5}{*}{ Acer platanoides (TA) } & A1 & - & - & - & - & - & - & - & - & - & - & - & - & - & - & - & - & - & - & 2 & 1 & $1-2$ & I & 10 \\
\hline & A2 & - & - & - & - & - & - & - & - & - & - & 1 & - & - & - & - & - & - & - & 2 & - & $1-2$ & I & 10 \\
\hline & B1 & - & - & - & - & - & - & - & - & - & - & - & - & - & + & - & - & - & - & 1 & - & +-1 & I & 10 \\
\hline & B2 & - & - & - & - & - & - & - & - & - & + & + & - & + & + & - & - & - & - & 2 & + & +-2 & II & 30 \\
\hline & $\mathrm{S}$ & - & - & - & - & - & - & - & - & - & + & 1 & - & + & + & - & - & - & - & 3 & 1 & +-3 & II & 30 \\
\hline Anemone ranunculoides & $\mathrm{C}$ & - & 2 & 2 & - & - & + & + & - & - & - & - & - & - & - & - & - & - & + & + & - & +-2 & II & 30 \\
\hline Vinca minor $(\mathrm{Cp})$ & $\mathrm{C}$ & - & - & - & - & - & - & - & - & - & - & - & - & - & 3 & 1 & 3 & - & + & 1 & 1 & +-3 & II & 30 \\
\hline Corydalis cava & C & 1 & - & - & - & - & - & - & - & - & - & + & 1 & - & - & - & - & - & - & 3 & - & +-3 & I & 20 \\
\hline Myosotis sparsiflora (GA, Cp) & $\mathrm{C}$ & - & - & - & + & + & + & + & - & - & - & - & - & - & - & - & - & - & - & - & - & + & I & 20 \\
\hline \multirow[t]{5}{*}{ Acer pseudo-platanus (TA) } & A1 & - & - & - & - & - & - & - & - & - & 1 & - & - & - & - & - & - & - & - & - & - & 1 & I & 5 \\
\hline & A2 & - & - & - & - & - & - & - & - & - & + & - & - & - & - & - & - & - & - & + & - & + & I & 10 \\
\hline & B1 & - & - & - & - & - & - & - & - & - & - & + & - & - & - & - & - & - & - & - & - & + & I & 5 \\
\hline & B2 & - & - & - & - & - & - & - & - & - & + & - & - & - & - & - & - & - & - & + & - & + & I & 10 \\
\hline & $\mathrm{S}$ & - & - & - & - & - & - & - & - & - & 1 & + & - & - & - & - & - & - & - & + & - & +-1 & I & 15 \\
\hline Arum orientale & $\mathrm{C}$ & - & - & - & - & - & - & - & - & - & - & - & + & - & - & - & - & - & - & + & 1 & +-1 & I & 15 \\
\hline Gagea lutea $(\mathrm{Ai}, \mathrm{Cp})$ & $\mathrm{C}$ & - & - & - & - & - & - & - & - & - & + & - & - & - & - & - & - & - & - & + & + & + & I & 15 \\
\hline Scilla vindobonensis $(\mathrm{Ai}, \mathrm{Cp})$ & $\mathrm{C}$ & - & 1 & 1 & - & - & - & - & - & 2 & - & - & - & - & - & - & - & - & - & - & - & $1-2$ & I & 15 \\
\hline Dryopteris filix-mas & $\mathrm{C}$ & - & - & - & - & - & - & - & - & - & - & - & - & - & - & + & - & + & - & - & - & + & I & 10 \\
\hline \multirow[t]{4}{*}{ Hedera helix } & A2 & - & - & - & - & - & - & - & - & - & - & - & - & - & - & - & - & - & - & + & - & + & I & 5 \\
\hline & B1 & - & - & - & - & - & - & - & - & - & - & - & - & - & - & - & - & - & - & + & - & + & I & 5 \\
\hline & B2 & - & - & - & - & - & - & - & - & - & - & - & - & - & - & - & - & - & - & 3 & + & +-3 & I & 10 \\
\hline & $\mathrm{S}$ & - & - & - & - & - & - & - & - & - & - & - & - & - & - & - & - & - & - & 3 & + & +-3 & I & 10 \\
\hline Stachys sylvatica (Epa) & $\mathrm{C}$ & - & + & - & - & - & - & - & - & - & - & - & - & - & + & - & - & - & - & - & - & + & I & 10 \\
\hline Allium ursinum & $\mathrm{C}$ & - & - & - & - & - & - & - & - & - & - & - & - & - & - & - & - & - & - & - & + & + & I & 5 \\
\hline Athyrium filix-femina (Qr, VP) & $\mathrm{C}$ & - & - & - & - & - & - & - & - & - & - & - & - & - & - & + & - & - & - & - & - & + & I & 5 \\
\hline
\end{tabular}


KEVEY et al. (2019): Zárt lösztölgyes maradványok a Mezőföldön

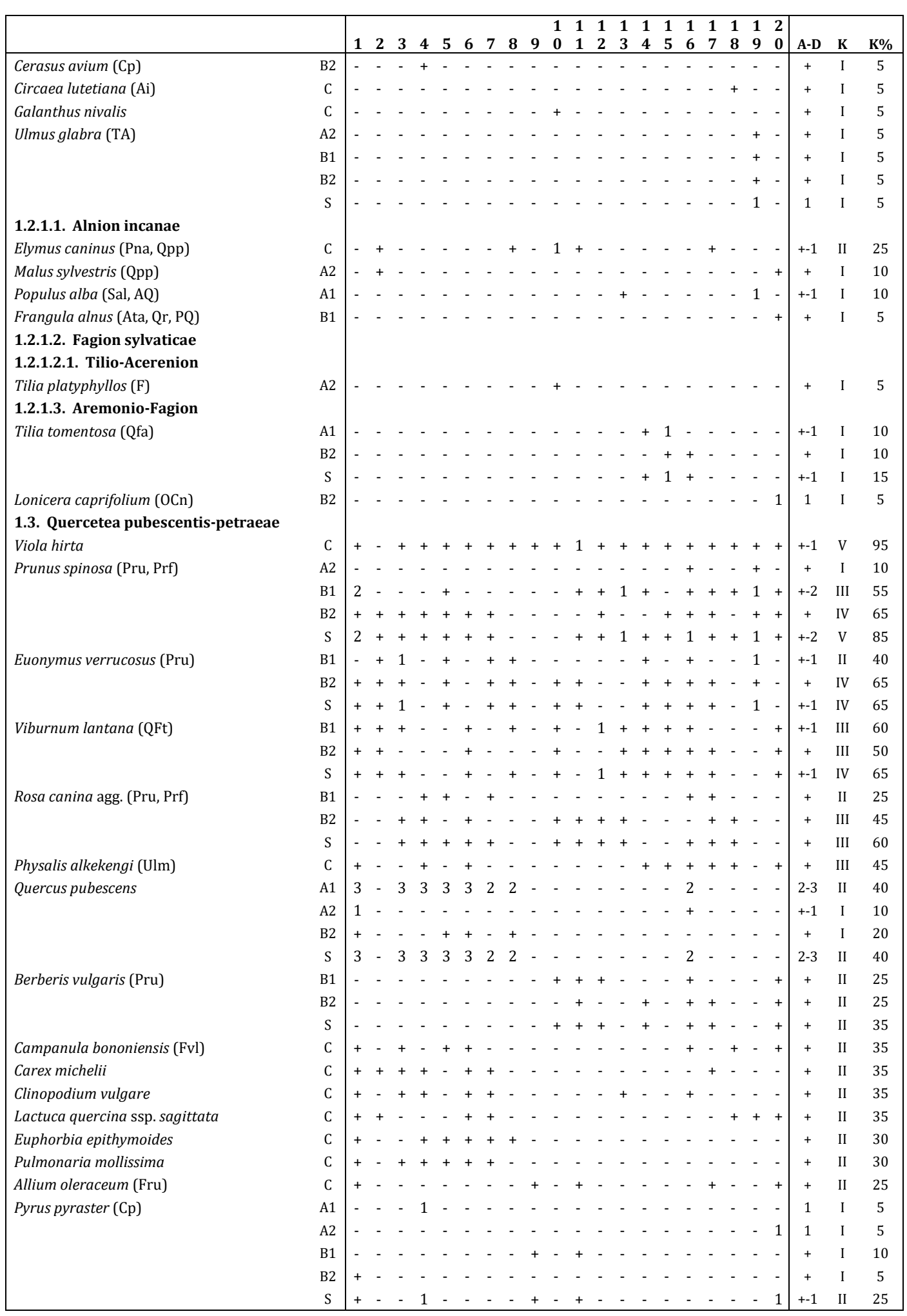


Kitaibelia 24(1): 66-93.

\begin{tabular}{|c|c|c|c|c|c|c|c|c|c|c|c|c|c|c|c|c|c|c|c|c|c|c|c|c|}
\hline & & 1 & 2 & 3 & 4 & 5 & 6 & 7 & 8 & 9 & $\begin{array}{l}\mathbf{1} \\
\mathbf{0}\end{array}$ & $\begin{array}{l}1 \\
1 \\
\end{array}$ & $\begin{array}{l}1 \\
2 \\
\end{array}$ & $\begin{array}{l}1 \\
3 \\
\end{array}$ & $\begin{array}{l}1 \\
4 \\
\end{array}$ & $\begin{array}{l}1 \\
5\end{array}$ & $\begin{array}{l}1 \\
6 \\
\end{array}$ & $\begin{array}{l}1 \\
7\end{array}$ & $\begin{array}{r}1 \\
8 \\
\end{array}$ & $\begin{array}{l}1 \\
9 \\
\end{array}$ & $\begin{array}{l}\mathbf{2} \\
\mathbf{0} \\
\end{array}$ & A-D & $\mathbf{K}$ & $\mathbf{K} \%$ \\
\hline \multirow[t]{5}{*}{ Fraxinus ornus (OCn) } & $\mathrm{A} 1$ & - & - & - & - & - & - & - & - & - & - & 1 & 2 & 4 & - & - & - & - & - & - & - & $1-4$ & I & 15 \\
\hline & A2 & - & - & - & - & - & - & - & - & - & 1 & 1 & 3 & 3 & - & - & - & - & - & - & - & $1-3$ & I & 20 \\
\hline & B1 & - & - & - & - & - & - & - & - & - & + & 1 & 2 & 2 & - & - & - & - & - & - & - & +-2 & I & 20 \\
\hline & B2 & - & - & - & - & - & - & - & - & - & + & + & 1 & 1 & - & - & - & - & - & - & - & +-1 & I & 20 \\
\hline & $\mathrm{S}$ & - & - & - & - & - & - & - & - & - & 1 & 2 & 4 & 5 & - & - & - & - & - & - & - & $1-5$ & I & 20 \\
\hline Hylotelephium telephium ssp. maximum & $\mathrm{C}$ & + & - & - & - & - & - & - & - & + & - & - & + & + & - & - & - & - & - & - & - & + & I & 20 \\
\hline Thalictrum aquilegiifolium & $\mathrm{C}$ & + & - & + & + & - & - & + & - & - & - & - & - & - & - & - & - & - & - & - & - & + & I & 20 \\
\hline Vincetoxicum hirundinaria $(\mathrm{Fvl})$ & $\mathrm{C}$ & - & - & - & - & - & - & - & - & + & - & - & - & - & - & - & + & - & + & - & + & + & I & 20 \\
\hline Arabis glabra $(\mathrm{Fvl})$ & $\mathrm{C}$ & - & - & - & - & - & - & - & - & - & - & - & + & + & - & - & + & - & - & - & - & + & I & 15 \\
\hline Asparagus officinalis (FBt) & $\mathrm{C}$ & + & - & - & - & - & + & - & - & + & - & - & - & - & - & - & - & - & - & - & - & + & I & 15 \\
\hline Buglossoides purpuro-coerulea (OCn, AQ) & $\mathrm{C}$ & - & 1 & 2 & - & - & - & - & - & 1 & - & - & - & - & - & - & - & - & - & - & - & $1-2$ & I & 15 \\
\hline \multirow[t]{3}{*}{ Cornus mas $(\mathrm{OCn}, \mathrm{Qc})$} & B1 & - & - & - & - & - & - & 1 & 2 & - & - & - & - & - & - & - & - & - & - & - & 3 & $1-3$ & I & 15 \\
\hline & B2 & - & - & - & - & - & - & - & - & - & - & - & - & - & - & - & - & - & - & - & + & + & I & 5 \\
\hline & $\mathrm{S}$ & - & - & - & - & - & - & 1 & 2 & - & - & - & - & - & - & - & - & - & - & - & 3 & $1-3$ & I & 15 \\
\hline Dictamnus albus (Fvl) & $\mathrm{C}$ & + & - & - & - & - & + & + & - & - & - & - & - & - & - & - & - & - & - & - & - & + & I & 15 \\
\hline Doronicum hungaricum (AQ) & $\mathrm{C}$ & + & - & - & + & 1 & - & - & - & - & - & - & - & - & - & - & - & - & - & - & - & +-1 & I & 15 \\
\hline Lactuca quercina ssp. quercina & $\mathrm{C}$ & - & - & - & - & - & - & - & + & - & + & + & - & - & - & - & - & - & - & - & - & + & I & 15 \\
\hline Verbascum chaixii ssp. austriacum (Fvl) & $\mathrm{C}$ & + & - & - & + & - & - & - & - & + & - & - & - & - & - & - & - & - & - & - & - & + & I & 15 \\
\hline Polygonatum odoratum (Fvl) & $\mathrm{C}$ & + & - & - & - & - & + & - & - & - & - & - & - & - & - & - & - & - & - & - & - & + & I & 10 \\
\hline Geranium divaricatum (GA) & $\mathrm{C}$ & - & - & - & - & - & - & - & - & - & - & - & - & + & - & - & - & - & - & - & - & + & I & 5 \\
\hline Iris variegata $(\mathrm{Fvl})$ & $\mathrm{C}$ & - & - & - & - & - & - & - & - & + & - & - & - & - & - & - & - & - & - & - & - & + & I & 5 \\
\hline Lembotropis nigricans (Qr, $\mathrm{PQ})$ & $\mathrm{C}$ & - & - & - & - & - & - & - & - & - & - & - & - & - & - & - & - & - & - & - & + & + & I & 5 \\
\hline Lithospermum officinale & $\mathrm{C}$ & - & - & - & - & - & - & - & - & - & - & - & - & - & - & - & - & - & - & - & + & + & I & 5 \\
\hline Orchis purpurea $(\mathrm{F}, \mathrm{OCn})$ & $\mathrm{C}$ & - & - & - & - & - & - & - & - & - & - & - & - & - & - & - & - & - & - & - & + & + & I & 5 \\
\hline \multicolumn{25}{|l|}{ 1.3.1. Quercetalia cerridis } \\
\hline Gagea pratensis (Sea) & $\mathrm{C}$ & - & - & - & + & - & - & - & - & + & - & - & - & - & - & - & - & - & + & - & - & + & I & 15 \\
\hline Phlomis tuberosa (Fru, AQ) & $\mathrm{C}$ & - & + & - & + & + & - & - & - & - & - & - & - & - & - & - & - & - & - & - & - & + & I & 15 \\
\hline \multicolumn{25}{|l|}{ 1.3.1.1. Quercion petraeae } \\
\hline Festuca heterophylla (Qpp) & $\mathrm{C}$ & - & - & - & - & - & - & - & - & - & - & - & + & + & - & - & - & - & - & - & - & + & I & 10 \\
\hline \multicolumn{25}{|l|}{ 1.3.1.2. Aceri tatarici-Quercion } \\
\hline \multirow[t]{4}{*}{ Acer tataricum (Qpp) } & A2 & - & - & - & - & - & - & - & + & - & - & - & - & - & - & - & - & 1 & - & - & + & +-1 & I & 15 \\
\hline & B1 & - & - & + & - & - & - & - & - & - & - & - & - & - & - & - & - & - & - & - & 1 & +-1 & I & 10 \\
\hline & B2 & - & - & + & - & - & - & - & - & - & - & - & - & - & - & - & - & - & - & - & - & + & I & 5 \\
\hline & $\mathrm{S}$ & - & - & + & - & - & - & - & + & - & - & - & - & - & - & - & - & 1 & - & - & 1 & +-1 & I & 20 \\
\hline \multirow{2}{*}{\multicolumn{25}{|c|}{$\begin{array}{l}\text { 2. Cypero-Phragmitea } \\
\text { 2.1. Phragmitetea }\end{array}$}} \\
\hline & & & & & & & & & & & & & & & & & & & & & & & & \\
\hline Solanum dulcamara $(\mathrm{Cn}, \mathrm{Bia}, \mathrm{Spu})$ & $\mathrm{C}$ & - & - & - & - & - & - & - & - & - & - & - & - & - & + & + & - & - & - & - & - & + & I & 10 \\
\hline \multicolumn{25}{|l|}{ 3. Molinio-Arrhenatherea } \\
\hline Poa trivialis (Pte, $\mathrm{Spu}, \mathrm{Ata}, \mathrm{Ai})$ & $\mathrm{C}$ & + & - & - & + & - & - & - & + & - & - & - & - & - & - & - & - & - & - & - & - & + & I & 15 \\
\hline Poa pratensis (Qpp) & $\mathrm{C}$ & - & - & - & - & - & - & - & - & - & - & - & - & - & - & - & - & - & + & - & - & + & I & 5 \\
\hline 3.1. Molinio-Juncetea & & & & & & & & & & & & & & & & & & & & & & & & \\
\hline 3.1.1. Molinietalia coeruleae & & & & & & & & & & & & & & & & & & & & & & & & \\
\hline Valeriana officinalis (Mag, $\mathrm{FiC})$ & $\mathrm{C}$ & - & - & - & - & - & - & - & - & - & - & - & - & - & - & - & - & - & - & - & + & + & I & 5 \\
\hline 4. Festuco-Bromea & & & & & & & & & & & & & & & & & & & & & & & & \\
\hline 4.1. Festuco-Brometea & & & & & & & & & & & & & & & & & & & & & & & & \\
\hline Brachypodium pinnatum (Qpp) & $\mathrm{C}$ & + & + & - & + & + & - & - & - & - & - & - & - & - & - & - & - & - & + & - & - & + & II & 25 \\
\hline Thlaspi perfoliatum (Sea, Qpp) & $\mathrm{C}$ & - & - & - & - & - & - & - & - & - & - & - & - & - & - & - & + & - & + & - & + & + & I & 15 \\
\hline Arabis hirsuta (Qpp) & $\mathrm{C}$ & + & - & - & - & - & - & - & - & - & - & - & - & - & - & - & + & - & - & - & - & + & I & 10 \\
\hline Ranunculus polyanthemos (Qpp) & $\mathrm{C}$ & - & - & - & + & - & - & - & - & - & - & - & - & - & - & - & + & - & - & - & - & + & I & 10 \\
\hline Anthericum ramosum (Qpp) & $\mathrm{C}$ & + & - & - & - & - & - & - & - & - & - & - & - & - & - & - & - & - & - & - & - & + & I & 5 \\
\hline Muscari racemosum (Qpp) & $\mathrm{C}$ & - & - & - & - & - & - & - & - & - & - & - & - & - & - & - & - & - & - & - & + & + & I & 5 \\
\hline Salvia nemorosa (CyF, Che) & $\mathrm{C}$ & - & - & - & - & - & - & - & - & - & - & - & - & + & - & - & - & - & - & - & - & + & I & 5 \\
\hline 4.1.1. Festucetalia valesiacae & & & & & & & & & & & & & & & & & & & & & & & & \\
\hline Melica transsilvanica (Fvg) & $\mathrm{C}$ & - & - & - & - & - & - & - & - & - & - & - & + & + & - & - & - & - & + & - & - & + & I & 15 \\
\hline Galium glaucum (Qpp) & $\mathrm{C}$ & - & - & - & - & - & - & - & - & - & - & - & + & + & - & - & - & - & - & - & - & + & I & 10 \\
\hline Buglossoides arvensis (CyF, Sea) & $\mathrm{C}$ & - & - & - & - & - & - & - & - & - & - & - & - & - & - & - & - & - & - & - & + & + & I & 5 \\
\hline Festuca valesiaca (Qpp) & $\mathrm{C}$ & - & - & - & - & - & - & - & - & - & - & - & + & - & - & - & - & - & - & - & - & + & I & 5 \\
\hline
\end{tabular}


KEVEY et al. (2019): Zárt lösztölgyes maradványok a Mezőföldön

\begin{tabular}{|c|c|c|c|c|c|c|c|c|c|c|c|c|c|c|c|c|c|c|c|c|c|c|c|c|}
\hline & & 1 & 2 & 3 & 4 & 5 & 6 & 7 & 8 & 9 & $\begin{array}{l}1 \\
0 \\
\end{array}$ & $\begin{array}{l}1 \\
1 \\
\end{array}$ & $\begin{array}{l}1 \\
2 \\
\end{array}$ & $\begin{array}{l}1 \\
3 \\
\end{array}$ & $\begin{array}{l}1 \\
4 \\
\end{array}$ & $\begin{array}{l}1 \\
5 \\
\end{array}$ & $\begin{array}{l}1 \\
6 \\
\end{array}$ & $\begin{array}{l}1 \\
7 \\
\end{array}$ & $\begin{array}{l}1 \\
\mathbf{8} \\
\end{array}$ & $\begin{array}{l}1 \\
9 \\
\end{array}$ & $\begin{array}{l}\mathbf{2} \\
\mathbf{0} \\
\end{array}$ & A-D & $\mathbf{K}$ & $\mathbf{K} \%$ \\
\hline $\begin{array}{l}\text { Fragaria viridis }(Q p p) \\
\text { 4.1.1.1. Festucion rupicolae }\end{array}$ & $\mathrm{C}$ & + & - & - & - & - & - & - & - & - & - & - & - & - & - & - & - & - & - & - & - & + & I & 5 \\
\hline Vinca herbacea (Qpp) & $\mathrm{C}$ & + & - & - & - & - & + & - & - & + & - & - & - & - & - & - & - & - & - & - & - & + & I & 15 \\
\hline Ajuga laxmannii (AQ) & $\mathrm{C}$ & - & - & - & + & - & - & - & - & - & - & - & - & - & - & - & - & - & - & - & - & + & I & 5 \\
\hline Marrubium peregrinum (Onn) & $\mathrm{C}$ & - & - & - & - & - & - & - & - & - & - & - & - & + & - & - & - & - & - & - & - & + & I & 5 \\
\hline $\begin{array}{l}\text { Ranunculus illyricus (Qpp) } \\
\text { 4.1.1.2. Artemisio-Kochion }\end{array}$ & $\mathrm{C}$ & - & - & - & - & - & - & - & - & - & - & - & - & - & - & - & - & - & + & - & - & + & I & 5 \\
\hline $\begin{array}{l}\text { Agropyron cristatum (Fru) } \\
\text { 5. Chenopodio-Scleranthea }\end{array}$ & $\mathrm{C}$ & - & - & - & - & - & - & - & - & - & - & - & - & + & - & - & - & - & + & - & - & + & I & 10 \\
\hline Bromus sterilis (Che) & $\mathrm{C}$ & - & - & - & - & + & - & - & + & + & - & - & + & + & - & - & + & + & 1 & + & - & +-1 & III & 45 \\
\hline Cannabis sativa & $\mathrm{C}$ & - & + & - & - & - & - & - & + & - & - & - & - & + & - & - & - & + & + & + & - & + & II & 30 \\
\hline Lactuca serriola & $\mathrm{C}$ & - & - & - & - & - & - & - & - & + & - & - & - & + & + & - & - & - & - & - & - & + & I & 15 \\
\hline Fumaria schleicheri (Che, Pla) & $\mathrm{C}$ & + & - & - & - & - & - & - & - & - & - & - & - & - & + & - & - & - & - & - & - & + & I & 10 \\
\hline $\begin{array}{l}\text { Sisymbrium orientale (Sio) } \\
\text { 5.1. Secalietea }\end{array}$ & $\mathrm{C}$ & - & - & - & - & - & - & - & - & - & - & - & + & + & - & - & - & - & - & - & - & + & I & 10 \\
\hline Lamium purpureum (Che) & $\mathrm{C}$ & + & - & - & + & - & - & + & + & - & - & - & + & - & + & - & + & - & + & - & - & + & II & 40 \\
\hline Muscari comosum (FBt) & $\mathrm{C}$ & + & - & - & - & - & + & - & - & - & - & + & - & - & - & - & - & - & - & - & + & + & I & 20 \\
\hline Silene alba (Cau, GA) & $\mathrm{C}$ & + & - & - & - & - & - & - & - & - & - & - & - & - & - & - & + & - & + & - & - & + & I & 15 \\
\hline Silene noctiflora (Cau, GA) & $\mathrm{C}$ & - & - & - & - & - & - & - & + & - & - & - & - & + & - & - & - & - & - & - & - & + & I & 10 \\
\hline $\begin{array}{l}\text { Viola arvensis }(\mathrm{Fvl}, \mathrm{Qpp}) \\
\text { 5.1.1. Aperetalia } \\
\text { 5.1.1.1. Aphanion }\end{array}$ & $\mathrm{C}$ & - & - & - & - & - & - & - & - & - & - & - & - & - & - & - & + & - & - & - & - & + & I & 5 \\
\hline $\begin{array}{l}\text { Myosotis arvensis (Arn, CyF) } \\
\text { 5.2. Chenopodietea }\end{array}$ & $\mathrm{C}$ & - & - & - & - & - & - & - & - & - & - & - & + & - & - & - & - & - & - & - & - & + & I & 5 \\
\hline Ballota nigra (Arc) & $\mathrm{C}$ & + & + & + & + & + & + & - & + & 1 & + & + & + & + & + & + & + & + & + & + & - & +-1 & V & 90 \\
\hline Arctium minus (Arc, Bia, Pla) & $\mathrm{C}$ & + & - & - & + & - & - & + & + & + & + & + & - & - & - & - & - & - & + & - & - & + & II & 40 \\
\hline Arctium lappa (Arc, Pla, Spu) & $\mathrm{C}$ & - & + & - & - & + & + & - & - & - & - & - & - & - & - & - & - & - & - & + & - & + & I & 20 \\
\hline Leonurus cardiaca $(\operatorname{Arc})$ & $\mathrm{C}$ & - & - & - & - & + & - & - & - & + & - & - & + & - & - & - & - & - & - & + & - & + & I & 20 \\
\hline Euphorbia salicifolia $(\mathrm{Fvl})$ & $\mathrm{C}$ & - & - & - & - & - & - & + & + & - & - & - & - & - & - & - & - & - & - & - & - & + & I & 10 \\
\hline Rumex patientia $(\mathrm{Arc}, \mathrm{Cn}, \mathrm{AR})$ & $\mathrm{C}$ & - & - & - & - & - & - & - & - & - & - & - & - & - & - & - & - & - & + & + & - & + & I & 10 \\
\hline Falcaria vulgaris & $\mathrm{C}$ & - & - & - & - & - & - & - & - & - & - & - & - & + & - & - & - & - & - & - & - & + & I & 5 \\
\hline Geranium rotundifolium (Fvl, Qpp) & $\mathrm{C}$ & - & - & - & - & - & - & - & + & - & - & - & - & - & - & - & - & - & - & - & - & + & I & 5 \\
\hline $\begin{array}{l}\text { Nepeta cataria (Arc) } \\
\text { 5.2.1. Onopordetalia }\end{array}$ & $\mathrm{C}$ & - & - & - & - & - & - & - & - & - & - & - & - & - & - & - & - & - & + & - & - & + & I & 5 \\
\hline $\begin{array}{l}\text { Onopordum acantium (Arc, Bia, Pla) } \\
\text { 5.3. Galio-Urticetea } \\
\text { 5.3.1. Calystegietalia sepium } \\
\text { 5.3.1.1. Galio-Alliarion }\end{array}$ & $\mathrm{C}$ & - & - & - & - & - & - & - & - & - & - & - & - & + & - & - & - & - & - & - & - & + & I & 5 \\
\hline Alliaria petiolata (Epa) & $\mathrm{C}$ & + & + & + & + & + & + & 1 & 1 & + & 1 & + & 2 & 1 & + & - & + & + & + & + & + & +-2 & $\mathrm{~V}$ & 95 \\
\hline Chaerophyllum temulum & $\mathrm{C}$ & + & + & + & + & + & - & + & + & - & 1 & + & - & - & + & + & - & 1 & - & + & - & +-1 & IV & 65 \\
\hline Parietaria officinalis (Cn, TA) & $\mathrm{C}$ & - & + & - & - & - & + & + & + & 1 & - & - & 1 & + & - & - & - & + & - & + & - & +-1 & III & 45 \\
\hline Aethusa cynapium (Che) & $\mathrm{C}$ & - & + & + & - & - & - & - & - & - & - & - & - & - & - & + & - & + & - & - & - & + & $\mathrm{I}$ & 20 \\
\hline $\begin{array}{l}\text { Melissa officinalis (Qpp) } \\
\text { 5.3.1.2. Calystegion sepium }\end{array}$ & $\mathrm{C}$ & - & - & - & - & - & - & - & - & - & - & - & - & - & - & - & - & + & - & - & - & + & I & 5 \\
\hline $\begin{array}{l}\text { Bryonia alba (Arc, GA) } \\
\text { 6. Indifferens }\end{array}$ & $\mathrm{C}$ & - & - & - & - & - & - & - & - & - & - & - & - & - & - & - & - & - & + & - & - & + & I & 5 \\
\hline Galium aparine (Sea, Epa, QFt) & $\mathrm{C}$ & + & + & + & + & + & + & + & + & 1 & + & + & 1 & + & 1 & + & + & 1 & + & + & + & +-1 & $\mathrm{~V}$ & 100 \\
\hline Sambucus nigra (Epa, SaS, QFt) & $\begin{array}{c}\text { B1 } \\
\text { B2 } \\
\text { S }\end{array}$ & - & $\begin{array}{l}2 \\
+ \\
2\end{array}$ & $\begin{array}{l}+ \\
+\end{array}$ & $\begin{array}{l}+ \\
+ \\
+\end{array}$ & $\begin{array}{l}- \\
+ \\
+\end{array}$ & $\begin{array}{l}+ \\
+\end{array}$ & $\begin{array}{l}+ \\
+ \\
+\end{array}$ & $\begin{array}{l}1 \\
+ \\
1\end{array}$ & $\begin{array}{l}1 \\
+\end{array}$ & $\begin{array}{l}+ \\
+ \\
+\end{array}$ & + & $\begin{array}{l}+ \\
- \\
+\end{array}$ & $\begin{array}{l}+ \\
- \\
+\end{array}$ & $\begin{array}{l}+ \\
- \\
+\end{array}$ & $\begin{array}{l}1 \\
+ \\
1\end{array}$ & $\begin{array}{l}- \\
+\end{array}$ & $\begin{array}{l}+ \\
+ \\
+\end{array}$ & $\begin{array}{l}+ \\
+ \\
+\end{array}$ & $\begin{array}{l}2 \\
+ \\
2\end{array}$ & $\begin{array}{l}1 \\
- \\
1\end{array}$ & $\begin{array}{c}+-2 \\
+ \\
+-2\end{array}$ & $\begin{array}{c}\mathrm{V} \\
\mathrm{IV} \\
\mathrm{V}\end{array}$ & $\begin{array}{l}85 \\
70 \\
95\end{array}$ \\
\hline Anthriscus cerefolium (Arc, GA) & $\mathrm{C}$ & + & - & + & + & + & - & + & + & + & + & + & 2 & 1 & + & + & + & + & + & + & - & +-2 & $\mathrm{~V}$ & 85 \\
\hline Urtica dioica (Arc, GA, Epa, Spu) & $\mathrm{C}$ & + & + & + & + & + & + & + & + & - & - & - & - & - & + & + & + & + & + & + & - & + & IV & 70 \\
\hline Chelidonium majus (Che, Arc, GA, Epa) & $\mathrm{C}$ & - & 1 & + & + & + & - & - & 2 & - & + & + & 1 & + & 2 & 2 & + & - & - & 1 & - & +-2 & IV & 65 \\
\hline Stellaria media (ChS, QFt, Spu) & $\mathrm{C}$ & + & + & + & + & - & - & + & + & + & + & + & 1 & - & - & - & + & - & + & + & - & +-1 & IV & 65 \\
\hline Ornithogalum umbellatum (Ara, FBt, Sea) & $\mathrm{C}$ & - & + & - & + & + & + & + & - & + & + & 1 & + & - & - & - & - & - & + & + & + & +-1 & III & 60 \\
\hline Taraxacum officinale agg. (MoA, ChS) & $\mathrm{C}$ & + & - & - & + & + & - & + & - & - & - & - & - & + & - & - & + & - & - & + & - & + & II & 35 \\
\hline
\end{tabular}


Kitaibelia 24(1): 66-93.

\begin{tabular}{|c|c|c|c|c|c|c|c|c|c|c|c|c|c|c|c|c|c|c|c|c|c|c|c|c|}
\hline & & 1 & 2 & 3 & 4 & 5 & 6 & 7 & 8 & 9 & $\begin{array}{l}\mathbf{1} \\
\mathbf{0}\end{array}$ & $\begin{array}{l}1 \\
1 \\
\end{array}$ & $\begin{array}{l}1 \\
2 \\
\end{array}$ & $\begin{array}{l}1 \\
\mathbf{3} \\
\end{array}$ & $\begin{array}{l}1 \\
4 \\
\end{array}$ & $\begin{array}{l}\mathbf{1} \\
\mathbf{5} \\
\end{array}$ & $\begin{array}{l}1 \\
6 \\
\end{array}$ & $\begin{array}{l}1 \\
7 \\
\end{array}$ & $\begin{array}{l}1 \\
8 \\
\end{array}$ & $\begin{array}{l}1 \\
9 \\
\end{array}$ & $\begin{array}{l}2 \\
0 \\
\end{array}$ & A-D & $\mathbf{K}$ & $\mathbf{K} \%$ \\
\hline Allium scorodoprasum (Qpp, Sea, Che) & $\mathrm{C}$ & + & - & - & - & - & + & - & - & + & - & - & - & - & - & - & - & - & + & - & + & + & II & 25 \\
\hline Torilis japonica (Arc, GA, Epa, QFt) & $\mathrm{C}$ & + & - & + & - & - & - & - & - & - & - & - & - & - & + & + & - & - & - & - & + & + & II & 25 \\
\hline Hypericum perforatum (NA, FB, Qpp) & $\mathrm{C}$ & - & - & - & - & - & + & - & - & - & - & - & + & + & - & - & + & - & - & - & - & + & I & 20 \\
\hline Euphorbia cyparissias (FB, ChS, Epa, Qpp) & $\mathrm{C}$ & - & - & - & - & - & - & + & - & - & - & - & - & + & - & - & + & - & - & - & - & + & I & 15 \\
\hline Galium mollugo (MoA, FBt, Qrp, Qpp) & $\mathrm{C}$ & - & - & - & - & - & - & + & - & - & - & - & - & - & - & - & + & + & - & - & - & + & I & 15 \\
\hline Ornithogalum boucheanum (Sea, Arc, Qpp) & $\mathrm{C}$ & - & - & - & - & - & - & - & - & - & - & + & + & - & - & - & - & - & + & - & - & + & I & 15 \\
\hline Poa angustifolia (Ara, FPi, FBt, ChS, Qpp) & $\mathrm{C}$ & - & - & - & - & - & - & - & - & - & - & - & + & + & - & - & - & - & + & - & - & + & I & 15 \\
\hline Agrimonia eupatoria (FBt, Qpp) & $\mathrm{C}$ & + & - & - & - & - & + & - & - & - & - & - & - & - & - & - & - & - & - & - & - & + & I & 10 \\
\hline Rubus caesius (Spu) & B2 & + & - & - & - & - & + & - & - & - & - & - & - & - & - & - & - & - & - & - & - & + & I & 10 \\
\hline Ajuga genevensis (Ara, FBt, Qpp) & $\mathrm{C}$ & - & - & - & - & - & - & - & - & - & - & - & - & + & - & - & - & - & - & - & - & + & I & 5 \\
\hline Conium maculatum (CyF, Arc, Cn, Bia) & $\mathrm{C}$ & - & - & - & - & - & - & - & + & - & - & - & - & - & - & - & - & - & - & - & - & + & I & 5 \\
\hline Cruciata laevipes (Arn, Fru, Arc, Cia, Qpp) & $\mathrm{C}$ & + & - & - & - & - & - & - & - & - & - & - & - & - & - & - & - & - & - & - & - & + & I & 5 \\
\hline Dactylis glomerata (MoA, FB, Che, Pla, Qpp) & $\mathrm{C}$ & - & - & - & - & - & - & - & - & + & - & - & - & - & - & - & - & - & - & - & - & + & I & 5 \\
\hline Elymus repens (MoA, $\mathrm{FPi}, \mathrm{FB}, \mathrm{ChS}, \mathrm{Pla})$ & $\mathrm{C}$ & - & - & - & - & - & - & - & - & - & - & - & - & + & - & - & - & - & - & - & - & + & I & 5 \\
\hline Glechoma hederacea (MoA, QFt, Sal, Ai) & $\mathrm{C}$ & - & - & - & - & - & - & - & - & - & - & - & - & - & - & - & - & - & + & - & - & + & I & 5 \\
\hline Lysimachia nummularia (Pte, Moa, Bia) & $\mathrm{C}$ & - & - & - & - & - & - & - & - & - & - & - & - & - & - & + & - & - & - & - & - & + & I & 5 \\
\hline Poa bulbosa (FPe, FB, Sea, Che) & $\mathrm{C}$ & - & - & - & - & - & - & - & - & - & - & - & - & - & - & - & - & - & + & - & - & + & I & 5 \\
\hline Rubus fruticosus agg. (QFt, Epa, SaS) & B2 & - & - & - & - & - & - & + & - & - & - & - & - & - & - & - & - & - & - & - & - & + & I & 5 \\
\hline Silene vulgaris (Ara, Fvl, Qpp) & $\mathrm{C}$ & - & - & - & - & + & - & - & - & - & - & - & - & - & - & - & - & - & - & - & - & + & I & 5 \\
\hline \multicolumn{24}{|l|}{ 7. Adventiva } & 5 \\
\hline \multirow[t]{5}{*}{ Celtis occidentalis } & $\mathrm{A} 1$ & 2 & 1 & 1 & - & - & - & - & + & 1 & 1 & 2 & 1 & - & 1 & 1 & - & 2 & 2 & - & 4 & +-4 & IV & 65 \\
\hline & A2 & 2 & 1 & 1 & - & - & - & - & - & + & 2 & 2 & - & 1 & 1 & + & + & 2 & 2 & 1 & 2 & +-2 & IV & 70 \\
\hline & B1 & + & 1 & + & - & - & - & + & + & - & 3 & 2 & 2 & 2 & + & 1 & - & 2 & 2 & 1 & 1 & +-3 & IV & 75 \\
\hline & B2 & + & + & - & + & - & + & + & + & + & 1 & 1 & 1 & 1 & + & + & 1 & + & 1 & + & 1 & +-1 & $\mathrm{~V}$ & 90 \\
\hline & $\mathrm{S}$ & 3 & 2 & 2 & + & - & + & + & 1 & 1 & 4 & 3 & 2 & 2 & 2 & 2 & 1 & 3 & 3 & 2 & 5 & +-5 & $\mathrm{~V}$ & 95 \\
\hline \multirow[t]{5}{*}{ Robinia pseudo-acacia } & $\mathrm{A} 1$ & - & + & 1 & 1 & + & 1 & + & - & 1 & - & - & + & - & - & - & - & - & 2 & - & - & +-2 & III & 45 \\
\hline & A2 & 1 & - & + & 1 & + & + & 1 & + & - & - & - & - & + & - & - & - & - & 1 & + & - & +-1 & III & 50 \\
\hline & B1 & + & - & - & + & - & - & - & - & + & - & - & + & - & - & - & - & - & - & - & - & + & I & 20 \\
\hline & B2 & - & + & - & - & - & - & - & - & + & - & - & - & - & - & - & - & - & - & - & - & + & I & 10 \\
\hline & $\mathrm{S}$ & 1 & + & 1 & 2 & + & 1 & 1 & + & 1 & - & - & + & + & - & - & - & - & 2 & + & - & +-2 & IV & 65 \\
\hline \multirow[t]{4}{*}{ Ailanthus altissima } & $\mathrm{A} 1$ & - & - & - & - & - & - & - & - & - & - & 1 & - & - & - & - & - & - & - & - & - & 1 & I & 5 \\
\hline & B1 & - & - & - & - & - & - & - & - & - & - & 1 & - & - & - & - & - & - & - & - & - & 1 & I & 5 \\
\hline & B2 & - & - & - & + & - & - & - & - & - & - & - & - & - & - & + & + & - & + & + & - & + & II & 25 \\
\hline & $\mathrm{S}$ & - & - & - & + & - & - & - & - & - & - & 2 & - & - & - & + & + & - & + & + & - & +-2 & II & 30 \\
\hline \multirow[t]{5}{*}{ Morus alba } & A1 & - & - & + & - & - & - & 1 & - & - & - & - & - & - & - & 1 & - & - & - & - & - & +-1 & I & 15 \\
\hline & A2 & - & - & - & - & - & - & - & - & - & - & - & - & - & - & - & - & - & + & - & - & + & I & 5 \\
\hline & B1 & - & - & - & - & - & - & - & - & - & - & - & - & - & + & - & - & - & - & - & - & + & I & 5 \\
\hline & B2 & - & - & - & - & - & - & - & - & - & - & - & - & - & - & + & - & - & - & + & - & + & I & 10 \\
\hline & S & - & - & + & - & - & - & 1 & - & - & - & - & - & - & + & 1 & - & - & + & + & - & +-1 & II & 30 \\
\hline Stenactis annua & $\mathrm{C}$ & - & - & - & + & + & + & - & - & - & - & - & - & - & - & - & - & - & - & - & - & + & I & 15 \\
\hline Gleditsia triacanthos & $\mathrm{A} 1$ & - & - & 1 & - & - & - & - & - & - & + & - & - & - & - & - & - & - & - & - & - & +-1 & I & 10 \\
\hline \multirow[t]{3}{*}{ Juglans regia } & A2 & - & - & - & - & - & - & - & + & - & - & - & - & - & - & - & - & - & - & - & - & + & I & 5 \\
\hline & B2 & - & - & - & - & - & - & - & - & - & - & - & - & - & - & - & - & - & - & + & - & + & I & 5 \\
\hline & S & - & - & - & - & - & - & - & + & - & - & - & - & - & - & - & - & - & - & + & - & + & I & 10 \\
\hline \multirow[t]{4}{*}{ Vitis vulpina } & A2 & - & - & - & - & - & - & - & - & - & - & - & - & - & - & + & - & - & - & 1 & - & +-1 & I & 10 \\
\hline & B1 & - & - & - & - & - & - & - & - & - & - & - & - & - & - & + & - & - & - & - & - & + & I & 5 \\
\hline & B2 & - & - & - & - & - & - & - & - & - & - & - & - & - & - & - & - & - & - & + & - & + & I & 5 \\
\hline & $\mathrm{S}$ & - & - & - & - & - & - & - & - & - & - & - & - & - & - & + & - & - & - & 1 & - & +-1 & I & 10 \\
\hline Acer negundo & B2 & - & - & - & - & - & - & - & - & - & - & - & - & - & - & - & - & - & + & - & - & + & I & 5 \\
\hline Aesculus hippocastanum & $\mathrm{A} 1$ & - & - & - & - & - & - & - & - & - & - & - & - & - & - & - & - & - & - & 1 & - & 1 & I & 5 \\
\hline Aster $\times$ salignus & $\mathrm{C}$ & - & - & + & - & - & - & - & - & - & - & - & - & - & - & - & - & - & - & - & - & + & I & 5 \\
\hline Laburnum anagyroides & B1 & - & - & - & - & - & - & - & - & - & - & - & - & - & - & - & - & - & - & + & - & + & I & 5 \\
\hline Parthenocissus inserta & B2 & - & - & - & - & - & - & - & - & - & - & - & - & - & - & - & - & - & - & + & - & + & I & 5 \\
\hline Phytolacca americana & $\mathrm{C}$ & - & - & - & - & - & - & - & - & - & - & - & - & - & - & + & - & - & - & - & - & + & I & 5 \\
\hline Solidago gigantea & $\mathrm{C}$ & - & - & - & - & - & - & - & - & - & - & - & - & - & - & - & - & - & - & + & - & + & I & 5 \\
\hline Syringa vulgaris & B1 & - & - & - & - & - & - & - & - & + & - & - & - & - & - & - & - & - & - & - & - & + & $\mathrm{I}$ & 5 \\
\hline
\end{tabular}


KEVEY et al. (2019): Zárt lösztölgyes maradványok a Mezőföldön

2. táblázat Felvételi adatok (1)

Table 2 Data of relevés (1)

\begin{tabular}{|l|c|c|c|c|c|c|c|c|c|c|}
\hline \multicolumn{1}{|c|}{ 2/1. táblázat } & $\mathbf{1}$ & $\mathbf{2}$ & $\mathbf{3}$ & $\mathbf{4}$ & $\mathbf{5}$ & $\mathbf{6}$ & $\mathbf{7}$ & $\mathbf{8}$ & $\mathbf{9}$ & $\mathbf{1 0}$ \\
\hline Minta felvételi sorszáma & 3940 & 10926 & 10927 & 10928 & 10929 & 10930 & 14487 & 14488 & 10931 & 14485 \\
Felvételi évszám 1. & 2005 & 2006 & 2006 & 2006 & 2006 & 2006 & 2008 & 2007 & 1999 & 2007 \\
Felvételi időpont 1. & 04.17 & 04.26 & 04.26 & 04.25 & 04.25 & 04.25 & 04.17 & 04.19 & 04.02 & 04.18 \\
Felvételi évszám 2. & 2005 & 2006 & 2006 & 2006 & 2006 & 2006 & 2008 & 2007 & 1999 & 2008 \\
Felvételi időpont 2. & 06.04 & 07.01 & 07.01 & 06.01 & 07.01 & 07.01 & 06.21 & 06.12 & 08.16 & 06.22 \\
Tengerszint feletti magasság & 155 & 140 & 140 & 160 & 160 & 160 & 160 & 150 & 103 & 130 \\
Kitettség & $\mathrm{K}$ & ÉK & ÉK & $\mathrm{K}$ & $\mathrm{K}$ & $\mathrm{K}$ & $\mathrm{K}$ & ÉK & - & É \\
Lejtőszög (fok) & 5 & 5 & 5 & 20 & 15 & 20 & 20 & 20 & 0 & 15 \\
A1 borítása (\%) & 80 & 75 & 70 & 60 & 60 & 75 & 60 & 70 & 75 & 80 \\
A1 magassága (m) & 20 & 23 & 23 & 20 & 20 & 20 & 25 & 20 & 23 & 26 \\
A1 átlagos törzsátmérője (cm) & 50 & 45 & 40 & 55 & 60 & 40 & 70 & 50 & 70 & 45 \\
A2 borítása (\%) & 20 & 30 & 20 & 40 & 50 & 30 & 60 & 50 & 30 & 40 \\
A2 magassága (m) & 12 & 18 & 16 & 15 & 15 & 12 & 17 & 15 & 15 & 17 \\
B1 borítása (\%) & 40 & 50 & 50 & 70 & 60 & 50 & 70 & 50 & 60 & 50 \\
B1 magassága (m) & 2,5 & 2 & 2 & 2,5 & 3 & 3 & 3,5 & 3 & 2,5 & 2,5 \\
B2 borítása (\%) & 5 & 10 & 10 & 1 & 1 & 1 & 3 & 1 & 3 \\
C borítása (\%) & 30 & 70 & 70 & 50 & 50 & 30 & 10 & 70 & 70 \\
Felvételi terület nagysága (m²) & 1200 & 1600 & 1600 & 1600 & 1600 & 1600 & 1600 & 1600 & 1600 & 1600 \\
\hline
\end{tabular}

\begin{tabular}{|l|c|c|c|c|c|c|c|c|c|c|}
\hline \multicolumn{1}{|c|}{ 2/2. táblázat } & $\mathbf{1 1}$ & $\mathbf{1 2}$ & $\mathbf{1 3}$ & $\mathbf{1 4}$ & $\mathbf{1 5}$ & $\mathbf{1 6}$ & $\mathbf{1 7}$ & $\mathbf{1 8}$ & $\mathbf{1 9}$ & $\mathbf{2 0}$ \\
\hline Minta felvételi sorszáma & 14486 & 14489 & 14490 & 14491 & 14492 & 14493 & 14494 & 15834 & 15835 & 15836 \\
Felvételi évszám 1. & 2007 & 2007 & 2007 & 2007 & 2007 & 2007 & 2007 & 2008 & 1998 & 1982 \\
Felvételi időpont 1. & 04.18 & 04.18 & 04.18 & 04.19 & 04.19 & 04.19 & 04.19 & 06.21 & 04.18 & 03.30 \\
Felvételi évszám 2. & 2008 & 2008 & 2008 & 2008 & 2008 & 2008 & 2008 & 2010 & 1998 & 1982 \\
Felvételi időpont 2. & 06.22 & 06.20 & 06.20 & 06.22 & 06.22 & 06.22 & 06.22 & 04.28 & 07.22 & 06.10 \\
Tengerszint feletti magasság & 130 & 115 & 120 & 170 & 165 & 170 & 170 & 130 & 126 & 130 \\
Kitettség & DNy & ÉK & K & ÉK & É & ÉNy & ÉK & ÉK & É & ÉK \\
Lejtőszög (fok) & 10 & 10 & 5 & 25 & 15 & 20 & 20 & 25 & 30 & 5 \\
A1 borítása (\%) & 70 & 80 & 80 & 75 & 70 & 50 & 70 & 75 & 70 & 70 \\
A1 magassága (m) & 25 & 20 & 20 & 25 & 27 & 20 & 25 & 22 & 25 & 25 \\
A1 átlagos törzsátmérője (cm) & 45 & 45 & 50 & 45 & 50 & 40 & 50 & 40 & 55 & 60 \\
A2 borítása (\%) & 50 & 40 & 35 & 40 & 40 & 60 & 50 & 40 & 40 & 40 \\
A2 magassága (m) & 18 & 15 & 16 & 20 & 16 & 12 & 16 & 17 & 18 & 17 \\
B1 borítása (\%) & 60 & 50 & 60 & 70 & 50 & 70 & 60 & 25 & 60 & 80 \\
B1 magassága (m) & 2,5 & 3 & 3 & 3,5 & 4 & 4 & 3,5 & 2 & 2,5 & 3 \\
B2 borítása (\%) & 10 & 10 & 10 & 1 & 1 & 4 & 2 & 5 & 50 & 5 \\
C borítása (\%) & 90 & 70 & 60 & 75 & 80 & 70 & 85 & 25 & 90 \\
Felvételi terület nagysága (m²) & 1600 & 1600 & 1600 & 1600 & 1600 & 1600 & 1600 & 1600 & 1600 & 1600 \\
\hline
\end{tabular}

Hely: 1: Mezőszilas „Ozorai út”; 2-7: Lajoskomárom „Újmajor”; 8: Lajoskomárom „Tüskéspuszta”; 9: Aba „Holdvilág-tavak”; 10-11: Adony „Kerekréti-erdő”; 12-13: Dunaföldvár „Baracsi-löszfal”; 14-17: Alsószentiván „Külső-Dög-völgy”;

18: Pusztaegres „Téglaházi-völgy”; 19: Előszállás „Kastély-park”; 20: Dég „Kastély-park”

Alapkőzet: 1-50: lösz

Talaj: 1-50: barna erdőtalaj

Felvételt készítette: 1-6, 8-17: Kevey \& Lendvai ined.; 7, 18-20: Kevey ined. 
3. táblázat Felvételi adatok (2)

Table 3 Data of relevés (2)

\begin{tabular}{|c|c|c|c|c|c|c|c|}
\hline 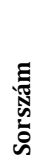 & 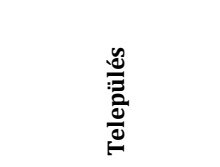 & 浔 & 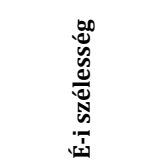 & 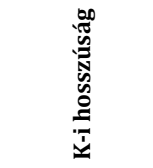 & 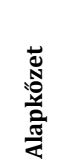 & 荵 & $\begin{array}{l}\text { : } \\
\text { N్d } \\
\text { N }\end{array}$ \\
\hline 1 & Mezőszilas & Ozorai-út & $46^{\circ} 47^{\prime} 11.31^{\prime \prime}$ & $18^{\circ} 25^{\prime} 17.77^{\prime \prime}$ & lösz & barna erdőtalaj & Kevey \& Lendvai ined. \\
\hline 2 & Lajoskomárom & Újmajor & $46^{\circ} 48^{\prime} 14.92^{\prime \prime}$ & $18^{\circ} 22^{\prime} 35.55^{\prime \prime}$ & lösz & barna erdőtalaj & Kevey \& Lendvai ined. \\
\hline 3 & Lajoskomárom & Újmajor & $46^{\circ} 48^{\prime} 28.27^{\prime \prime}$ & $18^{\circ} 22^{\prime} 27.86^{\prime \prime}$ & lösz & barna erdőtalaj & Kevey \& Lendvai ined. \\
\hline 4 & Lajoskomárom & Újmajor & $46^{\circ} 48^{\prime} 46.92^{\prime \prime}$ & $18^{\circ} 22^{\prime} 36.60^{\prime \prime}$ & lösz & barna erdőtalaj & Kevey \& Lendvai ined. \\
\hline 5 & Lajoskomárom & Újmajor & $46^{\circ} 48^{\prime} 49.08^{\prime \prime}$ & $18^{\circ} 22^{\prime} 35.47^{\prime \prime}$ & lösz & barna erdőtalaj & Kevey \& Lendvai ined. \\
\hline 6 & Lajoskomárom & Újmajor & $46^{\circ} 48^{\prime} 44.12^{\prime \prime}$ & $18^{\circ} 22^{\prime} 38.59^{\prime \prime}$ & lösz & barna erdőtalaj & Kevey \& Lendvai ined. \\
\hline 7 & Lajoskomárom & Újmajor & $46^{\circ} 48^{\prime} 42.21^{\prime \prime}$ & $18^{\circ} 22^{\prime} 39.49^{\prime \prime}$ & lösz & barna erdőtalaj & Kevey \& Lendvai ined. \\
\hline 8 & Lajoskomárom & Tüskéspuszta & $46^{\circ} 47^{\prime} 38.41^{\prime \prime}$ & $18^{\circ} 22^{\prime} 53.91^{\prime \prime}$ & lösz & barna erdőtalaj & Kevey \& Lendvai ined. \\
\hline 9 & Aba-Felsőszentiván & Holdvilág-tavak & $47^{\circ} 04^{\prime} 01.73^{\prime \prime}$ & $18^{\circ} 26^{\prime} 46.60^{\prime \prime}$ & lösz & barna erdőtalaj & Kevey ined. \\
\hline 10 & Adony & Kerekréti-erdő & $47^{\circ} 04^{\prime} 27.82^{\prime \prime}$ & $18^{\circ} 52^{\prime} 55.05^{\prime \prime}$ & lösz & barna erdőtalaj & Kevey \& Lendvai ined. \\
\hline 11 & Adony & Kerekréti-erdő & $47^{\circ} 04^{\prime} 27.39^{\prime \prime}$ & $18^{\circ} 52^{\prime} 50.61^{\prime \prime}$ & lösz & barna erdőtalaj & Kevey \& Lendvai ined. \\
\hline 12 & Dunaföldvár & Baracsi-löszfal & $46^{\circ} 50^{\prime} 51.90^{\prime \prime}$ & $18^{\circ} 55^{\prime} 10.09^{\prime \prime}$ & lösz & barna erdőtalaj & Kevey \& Lendvai ined. \\
\hline 13 & Dunaföldvár & Baracsi-löszfal & $46^{\circ} 50^{\prime} 49.81^{\prime \prime}$ & $18^{\circ} 55^{\prime} 08.70^{\prime \prime}$ & lösz & barna erdőtalaj & Kevey \& Lendvai ined. \\
\hline 14 & Alsószentiván & Külső-Dög-völgy & $46^{\circ} 46^{\prime} 15.29^{\prime \prime}$ & $18^{\circ} 45^{\prime} 33.67^{\prime \prime}$ & lösz & barna erdőtalaj & Kevey \& Lendvai ined. \\
\hline 15 & Alsószentiván & Külső-Dög-völgy & $46^{\circ} 46^{\prime} 14.19^{\prime \prime}$ & $18^{\circ} 45^{\prime} 38.26^{\prime \prime}$ & lösz & barna erdőtalaj & Kevey \& Lendvai ined. \\
\hline 16 & Alsószentiván & Külső-Dög-völgy & $46^{\circ} 46^{\prime} 14.27^{\prime \prime}$ & $18^{\circ} 45^{\prime} 43.90^{\prime \prime}$ & lösz & barna erdőtalaj & Kevey \& Lendvai ined. \\
\hline 17 & Alsószentiván & Külső-Dög-völgy & $46^{\circ} 46^{\prime} 12.28^{\prime \prime}$ & $18^{\circ} 45^{\prime} 55.84^{\prime \prime}$ & lösz & barna erdőtalaj & Kevey \& Lendvai ined. \\
\hline 18 & Pusztaegres & Téglaházi-völgy & $46^{\circ} 50^{\prime} 41.45^{\prime \prime}$ & $18^{\circ} 33^{\prime} 03.68^{\prime \prime}$ & lösz & barna erdőtalaj & Kevey ined. \\
\hline 19 & Előszállás & Kastély-park & $46^{\circ} 49^{\prime} 44.93^{\prime \prime}$ & $18^{\circ} 49^{\prime} 13.01^{\prime \prime}$ & lösz & barna erdőtalaj & Kevey ined. \\
\hline 20 & Dég & Kastély-park & $46^{\circ} 51^{\prime} 45.00^{\prime \prime}$ & $18^{\circ} 25^{\prime} 19.99^{\prime \prime}$ & lösz & barna erdőtalaj & Kevey ined. \\
\hline
\end{tabular}

4. táblázat Karakterfajok aránya (1)

Table 4 Percentage of character species (1)

PQ: Pulmonario mollis-Quercetum roboris, Mezőföld (Kevey \& Lendvai ined.: 20 felv.) AcQ: Aceri tatarici-Quercetum pubescentis-roboris, Mezőföld (LENDVAI et al. 2014a: 20 felv.)

\begin{tabular}{lcc|cc}
\hline \multirow{2}{*}{ Szüntaxonok } & Csoportrészesedés & \multicolumn{2}{c}{ Csoporttömeg } \\
\cline { 2 - 5 } & PQ & AcQ & PQ & AcQ \\
\hline Querco-Fagea & 0,00 & 0,00 & 0,00 & 0,00 \\
Salicetea purpureae & 0,00 & 0,00 & 0,00 & 0,00 \\
Salicetalia purpureae & 0,61 & 0,53 & 0,07 & 0,12 \\
Salicion albae & 0,19 & 0,04 & 0,04 & 0,01 \\
$\quad$ Populenion nigro-albae & 0,16 & 0,00 & 0,03 & 0,00 \\
Salicion albae s.l. & 0,35 & 0,04 & 0,07 & 0,01 \\
Salicetalia purpureae s.l. & 0,96 & 0,57 & 0,14 & 0,13 \\
Salicetea purpureae s.l. & 0,96 & 0,57 & 0,14 & 0,13 \\
Alnetea glutinosae & 0,00 & 0,00 & 0,00 & 0,00 \\
Alnetalia glutinosae & 0,13 & 0,06 & 0,01 & 0,01 \\
Alnetea glutinosae s.l. & 0,13 & 0,06 & 0,01 & 0,01 \\
Querco-Fagetea & 18,60 & 9,02 & 29,53 & 19,00 \\
Fagetalia sylvaticae & 4,10 & 0,41 & 4,15 & 0,08 \\
Alnion incanae & 1,40 & 0,41 & 5,29 & 2,60 \\
Ulmenion & 0,97 & 0,51 & 3,48 & 2,12 \\
Alnion incanae s.l. & 2,37 & 0,92 & 8,77 & 4,72 \\
Fagion sylvaticae & 0,00 & 0,00 & 0,00 & 0,00 \\
Carpinenion betuli & 2,91 & 1,36 & 3,20 & 1,44 \\
Tilio-Acerenion & 1,04 & 0,14 & 2,18 & 0,14 \\
\hline
\end{tabular}


KEvEY et al. (2019): Zárt lösztölgyes maradványok a Mezőföldön

\begin{tabular}{|c|c|c|c|c|}
\hline \multirow{2}{*}{ Szüntaxonok } & \multicolumn{2}{|c|}{ Csoportrészesedés } & \multicolumn{2}{|c|}{ Csoporttömeg } \\
\hline & PQ & AcQ & $\mathbf{P Q}$ & AcQ \\
\hline Fagion sylvaticae s.l. & 3,95 & 1,50 & 5,38 & 1,58 \\
\hline Aremonio-Fagion & 0,19 & 0,00 & 0,07 & 0,00 \\
\hline Fagetalia sylvaticae s.l. & 10,90 & 2,83 & 18,40 & 6,38 \\
\hline Quercetalia roboris & 0,08 & 0,10 & 0,01 & 0,02 \\
\hline Quercion robori-petraeae & 0,06 & 0,22 & 0,01 & 0,12 \\
\hline Quercetalia roboris s.l. & 0,14 & 0,32 & 0,02 & 0,14 \\
\hline Querco-Fagetea s.l. & 29,64 & 12,17 & 47,95 & 25,52 \\
\hline Quercetea pubescentis-petraeae & 26,24 & 29,59 & 30,61 & 44,52 \\
\hline Orno-Cotinetalia & 0,00 & 0,00 & 0,00 & 0,00 \\
\hline Orno-Cotinion & 0,46 & 0,30 & 2,19 & 1,26 \\
\hline Orno-Cotinetalia s.l. & 0,46 & 0,30 & 2,19 & 1,26 \\
\hline Quercetalia cerridis & 0,34 & 0,97 & 0,39 & 0,59 \\
\hline Quercion farnetto & 0,14 & 0,00 & 0,04 & 0,00 \\
\hline Quercion petraeae & 0,10 & 0,00 & 0,01 & 0,00 \\
\hline Aceri tatarici-Quercion & 0,64 & 1,18 & 0,28 & 1,94 \\
\hline Quercetalia cerridis s.l. & 1,22 & 2,15 & 0,72 & 2,53 \\
\hline Prunetalia spinosae & 2,39 & 2,09 & 1,05 & 4,03 \\
\hline Prunion fruticosae & 0,93 & 0,65 & 0,24 & 1,89 \\
\hline Prunetalia spinosae s.l. & 3,32 & 2,74 & 1,29 & 5,92 \\
\hline Quercetea pubescentis-petraeae s.l. & 30,95 & 34,78 & 34,78 & 54,23 \\
\hline Querco-Fagea s.l. & 61,68 & 47,58 & 82,88 & 79,89 \\
\hline Abieti-Piceea & 0,00 & 0,00 & 0,00 & 0,00 \\
\hline Erico-Pinetea & 0,00 & 0,00 & 0,00 & 0,00 \\
\hline Erico-Pinetalia & 0,00 & 0,00 & 0,00 & 0,00 \\
\hline Erico-Pinion & 0,00 & 0,25 & 0,00 & 0,10 \\
\hline Erico-Pinetalia s.l. & 0,00 & 0,25 & 0,00 & 0,10 \\
\hline Erico-Pinetea s.l. & 0,00 & 0,25 & 0,00 & 0,10 \\
\hline Vaccinio-Piceetea & 0,03 & 0,00 & 0,00 & 0,00 \\
\hline Pino-Quercetalia & 0,00 & 0,00 & 0,00 & 0,00 \\
\hline Pino-Quercion & 0,05 & 0,13 & 0,00 & 0,02 \\
\hline Pino-Quercetalia s.l. & 0,05 & 0,13 & 0,00 & 0,02 \\
\hline Vaccinio-Piceetea s.l. & 0,08 & 0,13 & 0,00 & 0,02 \\
\hline Abieti-Piceea s.l. & 0,08 & 0,38 & 0,00 & 0,12 \\
\hline Cypero-Phragmitea & 0,00 & 0,00 & 0,00 & 0,00 \\
\hline Phragmitetea & 0,13 & 0,11 & 0,01 & 0,02 \\
\hline Magnocaricetalia & 0,00 & 0,00 & 0,00 & 0,00 \\
\hline Magnocaricion & 0,03 & 0,00 & 0,00 & 0,00 \\
\hline Magnocaricetalia s.l. & 0,03 & 0,00 & 0,00 & 0,00 \\
\hline Phragmitetea s.l. & 0,16 & 0,11 & 0,01 & 0,02 \\
\hline Isoëto-Nanojuncetea & 0,00 & 0,00 & 0,00 & 0,00 \\
\hline Cypero-Phragmitea s.l. & 0,16 & 0,11 & 0,01 & 0,02 \\
\hline Molinio-Arrhenatherea & 0,60 & 1,49 & 0,06 & 0,55 \\
\hline Molinio-Juncetea & 0,02 & 0,30 & 0,00 & 0,09 \\
\hline Molinietalia coeruleae & 0,03 & 0,03 & 0,00 & 0,00 \\
\hline Molinion coeruleae & 0,00 & 0,03 & 0,00 & 0,01 \\
\hline Deschampsion caespitosae & 0,00 & 0,14 & 0,00 & 0,03 \\
\hline Filipendulo-Cirsion oleracei & 0,03 & 0,00 & 0,00 & 0,00 \\
\hline Alopecurion pratensis & 0,00 & 0,14 & 0,00 & 0,05 \\
\hline Molinietalia coeruleae s.l. & 0,06 & 0,34 & 0,00 & 0,09 \\
\hline Molinio-Juncetea s.l. & 0,08 & 0,64 & 0,00 & 0,18 \\
\hline Arrhenatheretea & 0,00 & 0,00 & 0,00 & 0,00 \\
\hline Arrhenatheretalia & 0,45 & 0,84 & 0,06 & 0,19 \\
\hline Arrhenatherion elatioris & 0,05 & 0,20 & 0,00 & 0,05 \\
\hline Arrhenatheretalia s.l. & 0,50 & 1,04 & 0,06 & 0,24 \\
\hline Arrhenatheretea s.l. & 0,50 & 1,04 & 0,06 & 0,24 \\
\hline
\end{tabular}


Kitaibelia 24(1): 66-93.

\begin{tabular}{|c|c|c|c|c|}
\hline \multirow{2}{*}{ Szüntaxonok } & \multicolumn{2}{|c|}{ Csoportrészesedés } & \multicolumn{2}{|c|}{ Csoporttömeg } \\
\hline & PQ & AcQ & PQ & AcQ \\
\hline Nardo-Callunetea & 0,00 & 0,00 & 0,00 & 0,00 \\
\hline Nardetalia & 0,00 & 0,00 & 0,00 & 0,00 \\
\hline Nardo-Agrostion tenuis & 0,08 & 0,27 & 0,01 & 0,05 \\
\hline Nardetalia s.l. & 0,08 & 0,27 & 0,01 & 0,05 \\
\hline Nardo-Callunetea s.l. & 0,08 & 0,27 & 0,01 & 0,05 \\
\hline Molinio-Arrhenatherea s.l. & 1,26 & 3,44 & 0,13 & 1,02 \\
\hline Puccinellio-Salicornea & 0,00 & 0,00 & 0,00 & 0,00 \\
\hline Festuco-Puccinellietea & 0,02 & 0,03 & 0,00 & 0,00 \\
\hline Festuco-Puccinellietalia & 0,06 & 0,11 & 0,01 & 0,02 \\
\hline Artemisio-Festucetalia pseudovinae & 0,00 & 0,00 & 0,00 & 0,00 \\
\hline Festucion pseudovinae & 0,00 & 0,05 & 0,00 & 0,01 \\
\hline Artemisio-Festucetalia pseudovinae s.l. & 0,00 & 0,05 & 0,00 & 0,01 \\
\hline Festuco-Puccinellietea s.l. & 0,08 & 0,19 & 0,01 & 0,03 \\
\hline Puccinellio-Salicornea s.l. & 0,08 & 0,19 & 0,01 & 0,03 \\
\hline Sedo-Corynephorea & 0,00 & 0,00 & 0,00 & 0,00 \\
\hline Koelerio-Corynephoretea & 0,00 & 0,00 & 0,00 & 0,00 \\
\hline Corynephoretalia & 0,00 & 0,01 & 0,00 & 0,00 \\
\hline Koelerio-Corynephoretea s.l. & 0,00 & 0,01 & 0,00 & 0,00 \\
\hline Sedo-Scleranthetea & 0,00 & 0,00 & 0,00 & 0,00 \\
\hline Sedo-Scleranthetalia & 0,00 & 0,00 & 0,00 & 0,00 \\
\hline Alysso-Sedion & 0,00 & 0,06 & 0,00 & 0,01 \\
\hline Sedo-Scleranthetalia s.l. & 0,00 & 0,06 & 0,00 & 0,01 \\
\hline Sedo-Scleranthetea s.l. & 0,00 & 0,06 & 0,00 & 0,01 \\
\hline Sedo-Corynephorea s.l. & 0,00 & 0,07 & 0,00 & 0,01 \\
\hline Festuco-Bromea & 0,19 & 1,74 & 0,02 & 0,43 \\
\hline Festucetea vaginatae & 0,00 & 0,00 & 0,00 & 0,00 \\
\hline Festucetalia vaginatae & 0,00 & 0,00 & 0,00 & 0,00 \\
\hline Festucion vaginatae & 0,14 & 0,74 & 0,01 & 0,28 \\
\hline Bromenion tectorum & 0,00 & 0,01 & 0,00 & 0,00 \\
\hline Festucion vaginatae s.l. & 0,14 & 0,75 & 0,01 & 0,28 \\
\hline Festucetalia vaginatae s.l. & 0,14 & 0,75 & 0,01 & 0,28 \\
\hline Festucetea vaginatae s.l. & 0,14 & 0,75 & 0,01 & 0,28 \\
\hline Festuco-Brometea & 1,41 & 7,42 & 0,16 & 2,66 \\
\hline Festucetalia valesiacae & 1,65 & 8,31 & 0,17 & 2,25 \\
\hline Festucion rupicolae & 0,73 & 2,98 & 0,08 & 0,85 \\
\hline Cynodonto-Festucenion & 0,11 & 0,58 & 0,01 & 0,11 \\
\hline Festucion rupicolae s.l. & 0,84 & 3,56 & 0,09 & 0,96 \\
\hline Artemisio-Kochion & 0,10 & 0,20 & 0,01 & 0,04 \\
\hline Festucetalia valesiacae s.l. & 2,59 & 12,07 & 0,27 & 3,25 \\
\hline Festuco-Brometea s.l. & 4,00 & 19,49 & 0,43 & 5,91 \\
\hline Festuco-Bromea s.l. & 4,33 & 21,98 & 0,46 & 6,62 \\
\hline Chenopodio-Scleranthea & 2,05 & 2,53 & 0,25 & 0,54 \\
\hline Secalietea & 2,04 & 2,53 & 0,27 & 0,51 \\
\hline Aperetalia & 0,00 & 0,00 & 0,00 & 0,00 \\
\hline Aphanion & 0,03 & 0,07 & 0,00 & 0,01 \\
\hline Aperetalia s.l. & 0,03 & 0,07 & 0,00 & 0,01 \\
\hline Secalietalia s.l. & 0,16 & 0,27 & 0,02 & 0,05 \\
\hline Eragrostetalia & 0,00 & 0,03 & 0,00 & 0,00 \\
\hline Consolido-Eragrostion minoris & 0,00 & 0,05 & 0,00 & 0,01 \\
\hline Eragrostetalia s.l. & 0,00 & 0,08 & 0,00 & 0,01 \\
\hline Secalietea s.l. & 2,23 & 2,95 & 0,29 & 0,58 \\
\hline Chenopodietea & 3,17 & 3,06 & 0,58 & 0,88 \\
\hline Sisymbrietalia & 0,00 & 0,03 & 0,00 & 0,00 \\
\hline Sisymbrion officinalis & 0,10 & 0,11 & 0,01 & 0,02 \\
\hline Artemisio-Agropyrion intermedii & 0,00 & 0,23 & 0,00 & 0,06 \\
\hline Sisymbrietalia s.l. & 0,10 & 0,37 & 0,01 & 0,08 \\
\hline
\end{tabular}


KEvEY et al. (2019): Zárt lösztölgyes maradványok a Mezőföldön

\begin{tabular}{|c|c|c|c|c|}
\hline \multirow{2}{*}{ Szüntaxonok } & \multicolumn{2}{|c|}{ Csoportrészesedés } & \multicolumn{2}{|c|}{ Csoporttömeg } \\
\hline & PQ & AcQ & PQ & AcQ \\
\hline Onopordetalia & 0,02 & 0,21 & 0,00 & 0,04 \\
\hline Onopordion acanthii & 0,05 & 0,26 & 0,00 & 0,05 \\
\hline Onopordetalia s.l. & 0,07 & 0,47 & 0,00 & 0,09 \\
\hline Chenopodietea s.l. & 3,34 & 3,90 & 0,59 & 1,05 \\
\hline Artemisietea & 0,00 & 0,00 & 0,00 & 0,00 \\
\hline Artemisietalia & 0,00 & 0,00 & 0,00 & 0,00 \\
\hline Arction lappae & 2,76 & 1,65 & 0,62 & 0,59 \\
\hline Artemisietalia s.l. & 2,76 & 1,65 & 0,62 & 0,59 \\
\hline Artemisietea s.l. & 2,76 & 1,65 & 0,62 & 0,59 \\
\hline Galio-Urticetea & 0,00 & 0,00 & 0,00 & 0,00 \\
\hline Calystegietalia sepium & 0,00 & 0,00 & 0,00 & 0,00 \\
\hline Galio-Alliarion & 5,22 & 2,43 & 1,25 & 0,95 \\
\hline Calystegion sepium & 0,55 & 0,66 & 0,09 & 0,14 \\
\hline Calystegietalia sepium s.l. & 5,77 & 3,09 & 1,34 & 1,09 \\
\hline Galio-Urticetea s.l. & 5,77 & 3,09 & 1,34 & 1,09 \\
\hline Bidentetea & 0,00 & 0,00 & 0,00 & 0,00 \\
\hline Bidentetalia & 0,29 & 0,35 & 0,03 & 0,06 \\
\hline Agropyro-Rumicion crispi & 0,05 & 0,07 & 0,00 & 0,01 \\
\hline Plantaginetalia majoris s.l. & 0,43 & 0,44 & 0,04 & 0,08 \\
\hline Plantaginetea s.l. & 0,43 & 0,44 & 0,04 & 0,08 \\
\hline Epilobietea angustifolii & 0,00 & 0,00 & 0,00 & 0,00 \\
\hline Epilobietalia & 4,21 & 2,18 & 1,85 & 0,67 \\
\hline Epilobietea angustifolii s.l. & 4,21 & 2,18 & 1,85 & 0,67 \\
\hline Urtico-Sambucetea & 0,00 & 0,00 & 0,00 & 0,00 \\
\hline Sambucetalia & 0,00 & 0,00 & 0,00 & 0,00 \\
\hline Sambuco-Salicion capreae & 0,48 & 0,20 & 0,24 & 0,04 \\
\hline Sambucetalia s.l. & 0,48 & 0,20 & 0,24 & 0,04 \\
\hline Urtico-Sambucetea s.l. & 0,48 & 0,20 & 0,24 & 0,04 \\
\hline Chenopodio-Scleranthea s.l. & 21,56 & 17,29 & 5,25 & 4,70 \\
\hline Indifferens & 3,73 & 3,94 & 0,96 & 1,20 \\
\hline Adventiva & 5,84 & 2,49 & 9,94 & 4,92 \\
\hline
\end{tabular}


5. táblázat Karakterfajok aránya (2)

Table 5 Percentage of character species (2)

Mf: Pulmonario mollis-Quercetum roboris, Mezőföld (Kevey \& Lendvai ined.: 20 felv.)

K: Pulmonario mollis-Quercetum roboris, Kerecsend (KEVEY 2011: 20 felv.)

Zm: Pulmonario mollis-Quercetum roboris, Zámolyi-medence (KeveY et al. 2015: 50 felv.)

Th: Pulmonario mollis-Quercetum roboris, Tolnai-hegyhát (KEVEY et al. 2018: 50 felv.)

HN: Pulmonario mollis-Quercetum roboris, Harkány-Nagynyárádi-sík (KEvEY 2016: 40 felv.)

\begin{tabular}{|c|c|c|c|c|c|c|c|c|c|c|}
\hline \multirow{2}{*}{ Szüntaxonok } & \multicolumn{5}{|c|}{ Csoportrészesedés } & \multicolumn{5}{|c|}{ Csoporttömeg } \\
\hline & Mf & $\mathbf{K}$ & $\mathbf{Z m}$ & Th & HN & Mf & $\mathbf{K}$ & $\mathbf{Z m}$ & Th & HN \\
\hline Querco-Fagea & 0,00 & 0,00 & 0,00 & 0,00 & 0,00 & 0,00 & 0,00 & 0,00 & 0,00 & 0,00 \\
\hline Salicetea purpureae & 0,00 & 0,00 & 0,00 & 0,00 & 0,00 & 0,00 & 0,00 & 0,00 & 0,00 & 0,00 \\
\hline Salicetalia purpureae & 0,61 & 0,06 & 0,32 & 0,24 & 0,22 & 0,07 & 0,01 & 0,04 & 0,03 & 0,05 \\
\hline Salicion albae & 0,19 & 0,00 & 0,13 & 0,07 & 0,21 & 0,04 & 0,00 & 0,02 & 0,01 & 0,02 \\
\hline Populenion nigro-albae & 0,16 & 0,66 & 0,22 & 0,95 & 1,05 & 0,03 & 0,30 & 0,04 & 0,14 & 0,27 \\
\hline Salicion albae s.l. & 0,35 & 0,66 & 0,35 & 1,02 & 1,26 & 0,07 & 0,30 & 0,06 & 0,15 & 0,29 \\
\hline Salicetalia purpureae s.l. & 0,96 & 0,72 & 0,67 & 1,26 & 1,48 & 0,14 & 0,31 & 0,10 & 0,18 & 0,34 \\
\hline Salicetea purpureae s.l. & 0,96 & 0,72 & 0,67 & 1,26 & 1,48 & 0,14 & 0,31 & 0,10 & 0,18 & 0,34 \\
\hline Alnetea glutinosae & 0,00 & 0,00 & 0,00 & 0,00 & 0,00 & 0,00 & 0,00 & 0,00 & 0,00 & 0,00 \\
\hline Alnetalia glutinosae & 0,13 & 0,00 & 0,02 & 0,05 & 0,11 & 0,01 & 0,00 & 0,00 & 0,01 & 0,01 \\
\hline Alnion glutinosae & 0,00 & 0,02 & 0,00 & 0,00 & 0,00 & 0,00 & 0,00 & 0,00 & 0,00 & 0,00 \\
\hline Alnetalia glutinosae s.l. & 0,13 & 0,02 & 0,02 & 0,05 & 0,11 & 0,01 & 0,00 & 0,00 & 0,01 & 0,01 \\
\hline Alnetea glutinosae s.l. & 0,13 & 0,02 & 0,02 & 0,05 & 0,11 & 0,01 & 0,00 & 0,00 & 0,01 & 0,01 \\
\hline Querco-Fagetea & 18,60 & 20,13 & 19,44 & 20,03 & 21,70 & 29,53 & 20,03 & 21,04 & 18,35 & 23,80 \\
\hline Fagetalia sylvaticae & 4,10 & 4,35 & 7,40 & 12,13 & 14,32 & 4,15 & 17,46 & 13,59 & 21,46 & 16,39 \\
\hline Alnion incanae & 1,40 & 1,57 & 1,00 & 2,13 & 2,63 & 5,29 & 0,76 & 0,76 & 1,08 & 4,35 \\
\hline Alnenion glutinosae-incanae & 0,00 & 0,00 & 0,02 & 0,00 & 0,26 & 0,00 & 0,00 & 0,01 & 0,00 & 0,13 \\
\hline Ulmenion & 0,97 & 0,21 & 0,70 & 0,82 & 0,69 & 3,48 & 0,30 & 0,38 & 0,22 & 1,65 \\
\hline Alnion incanae s.l. & 2,37 & 1,78 & 1,72 & 2,95 & 3,58 & 8,77 & 1,06 & 1,15 & 1,30 & 6,13 \\
\hline Fagion sylvaticae & 0,00 & 0,00 & 0,00 & 0,00 & 0,00 & 0,00 & 0,00 & 0,00 & 0,00 & 0,00 \\
\hline Carpinenion betuli & 2,91 & 3,53 & 3,77 & 6,19 & 4,81 & 3,20 & 1,80 & 2,71 & 4,17 & 5,86 \\
\hline Tilio-Acerenion & 1,04 & 0,62 & 1,52 & 1,58 & 0,85 & 2,18 & 0,45 & 2,89 & 4,63 & 0,81 \\
\hline Fagion sylvaticae s.l. & 3,95 & 4,15 & 5,29 & 7,77 & 5,66 & 5,38 & 2,25 & 5,60 & 8,80 & 6,67 \\
\hline Aremonio-Fagion & 0,19 & 0,00 & 0,59 & 0,33 & 2,64 & 0,07 & 0,00 & 1,27 & 0,47 & 1,19 \\
\hline Fagetalia sylvaticae s.l. & 10,90 & 10,28 & 15,00 & 23,18 & 26,20 & 18,40 & 20,77 & 21,61 & 32,03 & 30,38 \\
\hline Quercetalia roboris & 0,08 & 0,68 & 0,51 & 0,58 & 0,76 & 0,01 & 6,18 & 2,12 & 3,10 & 5,59 \\
\hline Quercion robori-petraeae & 0,06 & 0,47 & 0,10 & 0,07 & 0,07 & 0,01 & 0,04 & 0,01 & 0,01 & 0,01 \\
\hline Quercetalia roboris s.l. & 0,14 & 1,15 & 0,61 & 0,65 & 0,83 & 0,02 & 6,22 & 2,13 & 3,11 & 5,60 \\
\hline Querco-Fagetea s.l. & 29,64 & 31,56 & 35,05 & 43,86 & 48,73 & 47,95 & 47,02 & 44,78 & 53,49 & 59,78 \\
\hline Quercetea pubescentis-petraeae & 26,24 & 35,69 & 29,73 & 28,15 & 22,35 & 30,61 & 34,77 & 34,84 & 32,17 & 25,41 \\
\hline Orno-Cotinetalia & 0,00 & 0,00 & 0,00 & 0,00 & 0,00 & 0,00 & 0,00 & 0,00 & 0,00 & 0,00 \\
\hline Orno-Cotinion & 0,46 & 0,60 & 2,41 & 1,66 & 1,31 & 2,19 & 0,66 & 8,31 & 3,79 & 1,55 \\
\hline Orno-Cotinetalia s.l. & 0,46 & 0,60 & 2,41 & 1,66 & 1,31 & 2,19 & 0,66 & 8,31 & 3,79 & 1,55 \\
\hline Quercetalia cerridis & 0,34 & 3,07 & 1,68 & 1,11 & 0,58 & 0,39 & 0,31 & 1,97 & 3,25 & 0,27 \\
\hline Quercion farnetto & 0,14 & 0,00 & 0,00 & 0,31 & 1,38 & 0,04 & 0,00 & 0,00 & 0,46 & 0,40 \\
\hline Quercion petraeae & 0,10 & 0,14 & 0,00 & 0,16 & 0,14 & 0,01 & 0,01 & 0,00 & 0,02 & 0,02 \\
\hline Aceri tatarici-Quercion & 0,64 & 3,10 & 1,30 & 2,31 & 1,54 & 0,28 & 6,61 & 1,28 & 1,10 & 1,49 \\
\hline Quercetalia cerridis s.l. & 1,22 & 6,31 & 2,98 & 3,89 & 3,64 & 0,72 & 6,93 & 3,25 & 4,83 & 2,18 \\
\hline Prunetalia spinosae & 2,39 & 2,36 & 2,11 & 0,91 & 1,38 & 1,05 & 0,98 & 0,26 & 0,09 & 0,66 \\
\hline Prunion fruticosae & 0,93 & 1,20 & 0,77 & 0,49 & 0,85 & 0,24 & 0,83 & 0,08 & 0,05 & 0,60 \\
\hline Prunetalia spinosae s.l. & 3,32 & 3,56 & 2,88 & 1,40 & 2,23 & 1,29 & 1,81 & 0,34 & 0,14 & 1,26 \\
\hline Quercetea pubescentis-petraeae s.l. & 30,95 & 46,16 & 38,00 & 35,10 & 29,53 & 34,78 & 44,17 & 46,74 & 40,93 & 30,40 \\
\hline Querco-Fagea s.l. & 61,68 & 78,46 & 73,74 & 80,27 & 79,85 & 82,88 & 91,50 & 91,62 & 94,61 & 90,53 \\
\hline Abieti-Piceea & 0,00 & 0,00 & 0,00 & 0,00 & 0,00 & 0,00 & 0,00 & 0,00 & 0,00 & 0,00 \\
\hline Vaccinio-Piceetea & 0,03 & 0,00 & 0,00 & 0,00 & 0,00 & 0,00 & 0,00 & 0,00 & 0,00 & 0,00 \\
\hline Pino-Quercetalia & 0,00 & 0,00 & 0,00 & 0,00 & 0,00 & 0,00 & 0,00 & 0,00 & 0,00 & 0,00 \\
\hline Pino-Quercion & 0,05 & 0,73 & 0,49 & 0,58 & 0,71 & 0,00 & 6,19 & 2,12 & 3,10 & 5,59 \\
\hline Pino-Quercetalia s.l. & 0,05 & 0,73 & 0,49 & 0,58 & 0,71 & 0,00 & 6,19 & 2,12 & 3,10 & 5,59 \\
\hline Vaccinio-Piceetea s.l. & 0,08 & 0,73 & 0,49 & 0,58 & 0,71 & 0,00 & 6,19 & 2,12 & 3,10 & 5,59 \\
\hline Abieti-Piceea s.l. & 0,08 & 0,73 & 0,49 & 0,58 & 0,71 & 0,00 & 6,19 & 2,12 & 3,10 & 5,59 \\
\hline
\end{tabular}


KEvEY et al. (2019): Zárt lösztölgyes maradványok a Mezőföldön

\begin{tabular}{|c|c|c|c|c|c|c|c|c|c|c|}
\hline \multirow{2}{*}{ Szüntaxonok } & \multicolumn{5}{|c|}{ Csoportrészesedés } & \multicolumn{5}{|c|}{ Csoporttömeg } \\
\hline & Mf & $\mathbf{K}$ & $\mathbf{Z m}$ & Th & HN & Mf & $\mathbf{K}$ & $\mathrm{Zm}$ & Th & HN \\
\hline Cypero-Phragmitea & 0,00 & 0,00 & 0,00 & 0,00 & 0,00 & 0,00 & 0,00 & 0,00 & 0,00 & 0,00 \\
\hline Phragmitetea & 0,13 & 0,00 & 0,03 & 0,03 & 0,02 & 0,01 & 0,00 & 0,00 & 0,00 & 0,00 \\
\hline Phragmitetalia & 0,00 & 0,00 & 0,00 & 0,00 & 0,00 & 0,00 & 0,00 & 0,00 & 0,00 & 0,00 \\
\hline Phragmition & 0,00 & 0,00 & 0,00 & 0,00 & 0,00 & 0,00 & 0,00 & 0,00 & 0,00 & 0,00 \\
\hline Phragmitetalia s.l. & 0,00 & 0,00 & 0,00 & 0,00 & 0,00 & 0,00 & 0,00 & 0,00 & 0,00 & 0,00 \\
\hline Magnocaricetalia & 0,00 & 0,00 & 0,00 & 0,00 & 0,00 & 0,00 & 0,00 & 0,00 & 0,00 & 0,00 \\
\hline Magnocaricion & 0,03 & 0,02 & 0,00 & 0,10 & 0,00 & 0,00 & 0,00 & 0,00 & 0,01 & 0,00 \\
\hline Magnocaricetalia s.l. & 0,03 & 0,02 & 0,00 & 0,10 & 0,00 & 0,00 & 0,00 & 0,00 & 0,01 & 0,00 \\
\hline Phragmitetea s.l. & 0,16 & 0,02 & 0,03 & 0,13 & 0,02 & 0,01 & 0,00 & 0,00 & 0,01 & 0,00 \\
\hline Cypero-Phragmitea s.l. & 0,16 & 0,02 & 0,03 & 0,13 & 0,02 & 0,01 & 0,00 & 0,00 & 0,01 & 0,00 \\
\hline Molinio-Arrhenatherea & 0,60 & 0,10 & 0,36 & 0,56 & 0,68 & 0,06 & 0,01 & 0,04 & 0,05 & 0,08 \\
\hline Molinio-Juncetea & 0,02 & 0,00 & 0,00 & 0,03 & 0,00 & 0,00 & 0,00 & 0,00 & 0,00 & 0,00 \\
\hline Molinietalia coeruleae & 0,03 & 0,00 & 0,00 & 0,10 & 0,02 & 0,00 & 0,00 & 0,00 & 0,01 & 0,00 \\
\hline Filipendulo-Cirsion oleracei & 0,03 & 0,00 & 0,00 & 0,10 & 0,00 & 0,00 & 0,00 & 0,00 & 0,01 & 0,00 \\
\hline Molinietalia coeruleae s.l. & 0,06 & 0,00 & 0,00 & 0,20 & 0,02 & 0,00 & 0,00 & 0,00 & 0,02 & 0,00 \\
\hline Molinio-Juncetea s.l. & 0,08 & 0,00 & 0,00 & 0,23 & 0,02 & 0,00 & 0,00 & 0,00 & 0,02 & 0,00 \\
\hline Arrhenatheretea & 0,00 & 0,00 & 0,00 & 0,00 & 0,00 & 0,00 & 0,00 & 0,00 & 0,00 & 0,00 \\
\hline Arrhenatheretalia & 0,45 & 0,48 & 0,58 & 0,20 & 0,49 & 0,06 & 0,05 & 0,06 & 0,02 & 0,05 \\
\hline Arrhenatherion elatioris & 0,05 & 0,05 & 0,06 & 0,04 & 0,06 & 0,00 & 0,00 & 0,01 & 0,00 & 0,01 \\
\hline Arrhenatheretalia s.l. & 0,50 & 0,53 & 0,64 & 0,24 & 0,55 & 0,06 & 0,05 & 0,07 & 0,02 & 0,06 \\
\hline Arrhenatheretea s.l. & 0,50 & 0,53 & 0,64 & 0,24 & 0,55 & 0,06 & 0,05 & 0,07 & 0,02 & 0,06 \\
\hline Nardo-Callunetea & 0,00 & 0,00 & 0,00 & 0,00 & 0,00 & 0,00 & 0,00 & 0,00 & 0,00 & 0,00 \\
\hline Nardetalia & 0,00 & 0,00 & 0,00 & 0,00 & 0,00 & 0,00 & 0,00 & 0,00 & 0,00 & 0,00 \\
\hline Nardo-Agrostion tenuis & 0,08 & 0,09 & 0,07 & 0,07 & 0,03 & 0,01 & 0,01 & 0,01 & 0,01 & 0,00 \\
\hline Nardetalia s.l. & 0,08 & 0,09 & 0,07 & 0,07 & 0,03 & 0,01 & 0,01 & 0,01 & 0,01 & 0,00 \\
\hline Nardo-Callunetea s.l. & 0,08 & 0,09 & 0,07 & 0,07 & 0,03 & 0,01 & 0,01 & 0,01 & 0,01 & 0,00 \\
\hline Molinio-Arrhenatherea s.l. & 1,26 & 0,72 & 1,07 & 1,10 & 1,28 & 0,13 & 0,07 & 0,12 & 0,10 & 0,14 \\
\hline Puccinellio-Salicornea & 0,00 & 0,00 & 0,00 & 0,00 & 0,00 & 0,00 & 0,00 & 0,00 & 0,00 & 0,00 \\
\hline Festuco-Puccinellietea & 0,02 & 0,00 & 0,01 & 0,00 & 0,00 & 0,00 & 0,00 & 0,00 & 0,00 & 0,00 \\
\hline Festuco-Puccinellietalia & 0,06 & 0,00 & 0,00 & 0,00 & 0,00 & 0,01 & 0,00 & 0,00 & 0,00 & 0,00 \\
\hline Artemisio-Festetalia pseudovinae & 0,00 & 0,00 & 0,00 & 0,00 & 0,00 & 0,00 & 0,00 & 0,00 & 0,00 & 0,00 \\
\hline Festucion pseudovinae & 0,00 & 0,02 & 0,00 & 0,00 & 0,00 & 0,00 & 0,00 & 0,00 & 0,00 & 0,00 \\
\hline Artemisio-Festetaliapseudovinaes.l. & 0,00 & 0,02 & 0,00 & 0,00 & 0,00 & 0,00 & 0,00 & 0,00 & 0,00 & 0,00 \\
\hline Festuco-Puccinellietea s.l. & 0,08 & 0,02 & 0,01 & 0,00 & 0,00 & 0,01 & 0,00 & 0,00 & 0,00 & 0,00 \\
\hline Puccinellio-Salicornea s.l. & 0,08 & 0,02 & 0,01 & 0,00 & 0,00 & 0,01 & 0,00 & 0,00 & 0,00 & 0,00 \\
\hline Sedo-Corynephorea & 0,00 & 0,00 & 0,00 & 0,00 & 0,00 & 0,00 & 0,00 & 0,00 & 0,00 & 0,00 \\
\hline Sedo-Scleranthetea & 0,00 & 0,00 & 0,00 & 0,00 & 0,00 & 0,00 & 0,00 & 0,00 & 0,00 & 0,00 \\
\hline Sedo-Scleranthetalia & 0,00 & 0,00 & 0,00 & 0,00 & 0,00 & 0,00 & 0,00 & 0,00 & 0,00 & 0,00 \\
\hline Alysso-Sedion & 0,00 & 0,00 & 0,01 & 0,00 & 0,00 & 0,00 & 0,00 & 0,00 & 0,00 & 0,00 \\
\hline Sedo-Scleranthetalia s.l. & 0,00 & 0,00 & 0,01 & 0,00 & 0,00 & 0,00 & 0,00 & 0,00 & 0,00 & 0,00 \\
\hline Sedo-Scleranthetea s.l. & 0,00 & 0,00 & 0,01 & 0,00 & 0,00 & 0,00 & 0,00 & 0,00 & 0,00 & 0,00 \\
\hline Sedo-Corynephorea s.l. & 0,00 & 0,00 & 0,01 & 0,00 & 0,00 & 0,00 & 0,00 & 0,00 & 0,00 & 0,00 \\
\hline Festuco-Bromea & 0,19 & 0,15 & 0,12 & 0,17 & 0,04 & 0,02 & 0,01 & 0,01 & 0,02 & 0,00 \\
\hline Festucetea vaginatae & 0,00 & 0,00 & 0,00 & 0,00 & 0,00 & 0,00 & 0,00 & 0,00 & 0,00 & 0,00 \\
\hline Festucetalia vaginatae & 0,00 & 0,00 & 0,00 & 0,00 & 0,00 & 0,00 & 0,00 & 0,00 & 0,00 & 0,00 \\
\hline Festucion vaginatae & 0,14 & 0,00 & 0,07 & 0,00 & 0,00 & 0,01 & 0,00 & 0,01 & 0,00 & 0,00 \\
\hline Festucetalia vaginatae s.l. & 0,14 & 0,00 & 0,07 & 0,00 & 0,00 & 0,01 & 0,00 & 0,01 & 0,00 & 0,00 \\
\hline Festucetea vaginatae s.l. & 0,14 & 0,00 & 0,07 & 0,00 & 0,00 & 0,01 & 0,00 & 0,01 & 0,00 & 0,00 \\
\hline Festuco-Brometea & 1,41 & 1,26 & 1,21 & 0,31 & 0,16 & 0,16 & 0,12 & 0,15 & 0,04 & 0,02 \\
\hline Festucetalia valesiacae & 1,65 & 2,32 & 2,24 & 0,92 & 0,17 & 0,17 & 0,22 & 0,25 & 0,09 & 0,02 \\
\hline Bromo-Festucion pallentis & 0,00 & 0,00 & 0,00 & 0,01 & 0,00 & 0,00 & 0,00 & 0,00 & 0,00 & 0,00 \\
\hline Asplenio-Festucion pallentis & 0,00 & 0,00 & 0,00 & 0,05 & 0,00 & 0,00 & 0,00 & 0,00 & 0,00 & 0,00 \\
\hline Festucion rupicolae & 0,73 & 0,60 & 0,61 & 0,31 & 0,37 & 0,08 & 0,06 & 0,07 & 0,03 & 0,07 \\
\hline Cynodonto-Festucenion & 0,11 & 0,00 & 0,04 & 0,00 & 0,11 & 0,01 & 0,00 & 0,00 & 0,00 & 0,03 \\
\hline Festucion rupicolae s.l. & 0,84 & 0,60 & 0,65 & 0,31 & 0,48 & 0,09 & 0,06 & 0,07 & 0,03 & 0,10 \\
\hline Artemisio-Kochion & 0,10 & 0,00 & 0,00 & 0,00 & 0,00 & 0,01 & 0,00 & 0,00 & 0,00 & 0,00 \\
\hline Festucetalia valesiacae s.l. & 2,59 & 2,92 & 2,89 & 1,29 & 0,65 & 0,27 & 0,28 & 0,32 & 0,12 & 0,12 \\
\hline Festuco-Brometea s.l. & 4,00 & 4,18 & 4,10 & 1,60 & 0,81 & 0,43 & 0,40 & 0,47 & 0,16 & 0,14 \\
\hline Festuco-Bromea s.l. & 4,33 & 4,33 & 4,29 & 1,77 & 0,85 & 0,46 & 0,41 & 0,49 & 0,18 & 0,14 \\
\hline
\end{tabular}


Kitaibelia 24(1): 66-93.

\begin{tabular}{|c|c|c|c|c|c|c|c|c|c|c|}
\hline \multirow{2}{*}{ Szüntaxonok } & \multicolumn{5}{|c|}{ Csoportrészesedés } & \multicolumn{5}{|c|}{ Csoporttömeg } \\
\hline & Mf & $\mathbf{K}$ & Zm & Th & HN & Mf & $\mathbf{K}$ & $\mathrm{Zm}$ & Th & $\mathbf{H N}$ \\
\hline Chenopodio-Scleranthea & 2,05 & 0,04 & 1,20 & 0,79 & 0,47 & 0,25 & 0,00 & 0,12 & 0,08 & 0,05 \\
\hline Secalietea & 2,04 & 2,54 & 1,10 & 0,76 & 0,54 & 0,27 & 0,30 & 0,13 & 0,07 & 0,07 \\
\hline Aperetalia & 0,00 & 0,00 & 0,00 & 0,00 & 0,00 & 0,00 & 0,00 & 0,00 & 0,00 & 0,00 \\
\hline Aphanion & 0,03 & 0,00 & 0,00 & 0,00 & 0,00 & 0,00 & 0,00 & 0,00 & 0,00 & 0,00 \\
\hline Aperetalia s.l. & 0,03 & 0,00 & 0,00 & 0,00 & 0,00 & 0,00 & 0,00 & 0,00 & 0,00 & 0,00 \\
\hline Secalietalia & 0,00 & 0,00 & 0,00 & 0,00 & 0,00 & 0,00 & 0,00 & 0,00 & 0,00 & 0,00 \\
\hline Caucalidion platycarpos & 0,16 & 0,32 & 0,11 & 0,12 & 0,02 & 0,02 & 0,03 & 0,01 & 0,01 & 0,00 \\
\hline Secalietalia s.l. & 0,16 & 0,32 & 0,11 & 0,12 & 0,02 & 0,02 & 0,03 & 0,01 & 0,01 & 0,00 \\
\hline Secalietea s.l. & 2,23 & 2,86 & 1,21 & 0,88 & 0,56 & 0,29 & 0,33 & 0,14 & 0,08 & 0,07 \\
\hline Chenopodietea & 3,17 & 1,09 & 1,61 & 1,09 & 0,68 & 0,58 & 0,10 & 0,16 & 0,11 & 0,08 \\
\hline Sisymbrietalia & 0,00 & 0,00 & 0,00 & 0,00 & 0,00 & 0,00 & 0,00 & 0,00 & 0,00 & 0,00 \\
\hline Onopordetalia & 0,02 & 0,02 & 0,00 & 0,00 & 0,00 & 0,00 & 0,00 & 0,00 & 0,00 & 0,00 \\
\hline Onopordion acanthii & 0,05 & 0,00 & 0,07 & 0,05 & 0,05 & 0,00 & 0,00 & 0,01 & 0,01 & 0,01 \\
\hline Onopordetalia s.l. & 0,07 & 0,02 & 0,07 & 0,05 & 0,05 & 0,00 & 0,00 & 0,01 & 0,01 & 0,01 \\
\hline Chenopodietea s.l. & 3,34 & 1,11 & 1,68 & 1,14 & 0,73 & 0,59 & 0,10 & 0,17 & 0,12 & 0,09 \\
\hline Artemisietea & 0,00 & 0,00 & 0,00 & 0,00 & 0,00 & 0,00 & 0,00 & 0,00 & 0,00 & 0,00 \\
\hline Artemisietalia & 0,00 & 0,00 & 0,00 & 0,00 & 0,00 & 0,00 & 0,00 & 0,00 & 0,00 & 0,00 \\
\hline Arction lappae & 2,76 & 0,88 & 1,72 & 0,89 & 0,71 & 0,62 & 0,08 & 0,17 & 0,09 & 0,13 \\
\hline Artemisietalia s.l. & 2,76 & 0,88 & 1,72 & 0,89 & 0,71 & 0,62 & 0,08 & 0,17 & 0,09 & 0,13 \\
\hline Artemisietea s.l. & 2,76 & 0,88 & 1,72 & 0,89 & 0,71 & 0,62 & 0,08 & 0,17 & 0,09 & 0,13 \\
\hline Galio-Urticetea & 0,00 & 0,00 & 0,00 & 0,00 & 0,00 & 0,00 & 0,00 & 0,00 & 0,00 & 0,00 \\
\hline Calystegietalia sepium & 0,00 & 0,00 & 0,00 & 0,00 & 0,00 & 0,00 & 0,00 & 0,00 & 0,00 & 0,00 \\
\hline Galio-Alliarion & 5,22 & 2,55 & 3,42 & 3,24 & 3,66 & 1,25 & 0,41 & 1,48 & 0,50 & 0,57 \\
\hline Calystegion sepium & 0,55 & 0,00 & 0,56 & 0,23 & 0,47 & 0,09 & 0,00 & 0,06 & 0,02 & 0,16 \\
\hline Calystegietalia sepium s.l. & 5,77 & 2,55 & 3,98 & 3,47 & 4,13 & 1,34 & 0,41 & 1,54 & 0,52 & 0,73 \\
\hline Galio-Urticetea s.l. & 5,77 & 2,55 & 3,98 & 3,47 & 4,13 & 1,34 & 0,41 & 1,54 & 0,52 & 0,73 \\
\hline Bidentetea & 0,00 & 0,00 & 0,00 & 0,00 & 0,00 & 0,00 & 0,00 & 0,00 & 0,00 & 0,00 \\
\hline Bidentetalia & 0,29 & 0,00 & 0,33 & 0,17 & 0,02 & 0,03 & 0,00 & 0,03 & 0,02 & 0,00 \\
\hline Agropyro-Rumicion crispi & 0,05 & 0,00 & 0,00 & 0,00 & 0,00 & 0,00 & 0,00 & 0,00 & 0,00 & 0,00 \\
\hline Plantaginetalia majoris s.l. & 0,43 & 0,00 & 0,33 & 0,15 & 0,02 & 0,04 & 0,00 & 0,03 & 0,01 & 0,00 \\
\hline Plantaginetea s.l. & 0,43 & 0,00 & 0,33 & 0,15 & 0,02 & 0,04 & 0,00 & 0,03 & 0,01 & 0,00 \\
\hline Epilobietea angustifolii & 0,00 & 0,00 & 0,00 & 0,00 & 0,00 & 0,00 & 0,00 & 0,00 & 0,00 & 0,00 \\
\hline Epilobietalia & 4,21 & 4,49 & 3,58 & 4,55 & 4,27 & 1,85 & 0,49 & 1,71 & 0,60 & 0,75 \\
\hline Epilobion angustifolii & 0,00 & 0,41 & 0,00 & 0,00 & 0,14 & 0,00 & 0,04 & 0,00 & 0,00 & 0,02 \\
\hline Epilobietalia s.l. & 4,21 & 4,90 & 3,58 & 4,55 & 4,41 & 1,85 & 0,53 & 1,71 & 0,60 & 0,77 \\
\hline Epilobietea angustifolii s.l. & 4,21 & 4,90 & 3,58 & 4,55 & 4,41 & 1,85 & 0,53 & 1,71 & 0,60 & 0,77 \\
\hline Urtico-Sambucetea & 0,00 & 0,00 & 0,00 & 0,00 & 0,00 & 0,00 & 0,00 & 0,00 & 0,00 & 0,00 \\
\hline Sambucetalia & 0,00 & 0,00 & 0,00 & 0,00 & 0,00 & 0,00 & 0,00 & 0,00 & 0,00 & 0,00 \\
\hline Sambuco-Salicion capreae & 0,48 & 0,24 & 0,30 & 0,17 & 0,43 & 0,24 & 0,02 & 0,22 & 0,05 & 0,13 \\
\hline Sambucetalia s.l. & 0,48 & 0,24 & 0,30 & 0,17 & 0,43 & 0,24 & 0,02 & 0,22 & 0,05 & 0,13 \\
\hline Urtico-Sambucetea s.l. & 0,48 & 0,24 & 0,30 & 0,17 & 0,43 & 0,24 & 0,02 & 0,22 & 0,05 & 0,13 \\
\hline Chenopodio-Scleranthea s.l. & 21,56 & 12,58 & 14,33 & 12,21 & 11,48 & 5,25 & 1,47 & 4,13 & 1,57 & 1,97 \\
\hline Indifferens & 3,73 & 1,76 & 2,30 & 1,67 & 1,83 & 0,96 & 0,20 & 0,44 & 0,20 & 0,38 \\
\hline Adventiva & 5,84 & 0,19 & 2,76 & 1,42 & 3,19 & 9,94 & 0,02 & 0,95 & 0,14 & 1,16 \\
\hline
\end{tabular}


6. táblázat Flóraelemek aránya (1)

Table 6 Percentage of floristic elements (1)

PQ: Pulmonario mollis-Quercetum roboris, Mezőföld (Kevey és Lendvai ined.: 20 felv.) AcQ: Aceri tatarici-Quercetum pubescentis-roboris, Mezőföld (LendVAI et al. 2014a: 20 felv.)

\begin{tabular}{|c|c|c|c|c|}
\hline \multirow{2}{*}{ Flóraelemek } & \multicolumn{2}{|c|}{ Csoportrészesedés } & \multicolumn{2}{|c|}{ Csoporttömeg } \\
\hline & PQ & AcQ & PQ & AcQ \\
\hline KOZMOPOLITA & 0,00 & 0,00 & 0,00 & 0,00 \\
\hline Kozmopolita & 3,16 & 2,97 & 0,37 & 1,23 \\
\hline KOZMOPOLITA s.l. & 3,16 & 2,97 & 0,37 & 1,23 \\
\hline CIRKUMPOLÁRIS & 0,00 & 0,00 & 0,00 & 0,00 \\
\hline Cirkumpoláris & 7,76 & 6,41 & 1,62 & 1,87 \\
\hline CIRKUMPOLÁRIS s.l. & 7,76 & 6,41 & 1,62 & 1,87 \\
\hline EURÁZSIAI & 0,00 & 0,00 & 0,00 & 0,00 \\
\hline Eurázsiai & 27,30 & 32,41 & 14,21 & 16,08 \\
\hline Észak-eurázsiai & 0,00 & 0,05 & 0,00 & 0,01 \\
\hline Dél-eurázsiai & 1,25 & 2,99 & 0,18 & 0,73 \\
\hline Közép-eurázsiai & 1,82 & 0,73 & 0,67 & 0,47 \\
\hline EURÁZSIAI s.l. & 30,37 & 36,18 & 15,06 & 17,29 \\
\hline EURÓPAI & 0,00 & 0,00 & 0,00 & 0,00 \\
\hline Európai & 21,12 & 14,73 & 24,16 & 26,36 \\
\hline Közép-európai & 11,62 & 6,49 & 27,59 & 13,85 \\
\hline EURÓPAI s.l. & 32,74 & 21,22 & 51,75 & 40,21 \\
\hline SZUBATLANTI & 0,00 & 0,00 & 0,00 & 0,00 \\
\hline Szubatlanti & 0,13 & 0,03 & 0,38 & 0,00 \\
\hline SZUBATLANTI s.l. & 0,13 & 0,03 & 0,38 & 0,00 \\
\hline SZUBTRÓPUSI & 0,00 & 0,00 & 0,00 & 0,00 \\
\hline Szubtrópusi & 0,00 & 0,02 & 0,00 & 0,00 \\
\hline SZUBTRÓPUSI s.l. & 0,00 & 0,02 & 0,00 & 0,00 \\
\hline SZUBMEDITERRÁN & 0,00 & 0,00 & 0,00 & 0,00 \\
\hline Szubmediterrán & 8,22 & 9,02 & 8,27 & 18,31 \\
\hline Kelet-szubmediterrán & 1,39 & 1,54 & 3,99 & 2,60 \\
\hline Balkáni & 2,83 & 2,71 & 2,73 & 2,52 \\
\hline Kaukázusi & 0,13 & 0,18 & 0,05 & 0,92 \\
\hline SZUBMEDITERRÁN s.l. & 12,57 & 13,45 & 15,04 & 24,35 \\
\hline KONTINENTÁLIS & 0,00 & 0,00 & 0,00 & 0,00 \\
\hline Kontinentális & 0,72 & 4,19 & 0,07 & 0,90 \\
\hline Szubkontinentális & 1,29 & 0,97 & 1,81 & 1,28 \\
\hline Turáni & 0,29 & 0,16 & 0,03 & 0,03 \\
\hline Pontusi & 3,91 & 7,88 & 3,72 & 5,80 \\
\hline Szarmata & 0,00 & 0,02 & 0,00 & 0,00 \\
\hline KONTINENTÁLIS s.l. & 6,21 & 13,22 & 5,63 & 8,01 \\
\hline SZUBALPIN & 0,00 & 0,00 & 0,00 & 0,00 \\
\hline Szubalpin & 0,00 & 0,05 & 0,00 & 0,01 \\
\hline SZUBALPIN s.l. & 0,00 & 0,05 & 0,00 & 0,01 \\
\hline PANNONIAI & 0,00 & 0,00 & 0,00 & 0,00 \\
\hline Pannoniai & 1,13 & 3,89 & 0,20 & 2,07 \\
\hline PANNONIAI s.l. & 1,13 & 3,89 & 0,20 & 2,07 \\
\hline AFRIKAI & 0,00 & 0,00 & 0,00 & 0,00 \\
\hline Afrikai & 0,00 & 0,02 & 0,00 & 0,00 \\
\hline AFRIKAI s.l. & 0,00 & 0,02 & 0,00 & 0,00 \\
\hline ADVENTÍV & 0,00 & 0,00 & 0,00 & 0,00 \\
\hline Adventív & 5,94 & 2,54 & 9,95 & 4,93 \\
\hline ADVENTÍV s.l. & 5,94 & 2,54 & 9,95 & 4,93 \\
\hline
\end{tabular}


7. táblázat Flóraelemek aránya (2)

Table 7 Percentage of floristic elements (2)

Mf: Pulmonario mollis-Quercetum roboris, Mezőföld (Kevey \& Lendvai ined.: 20 felv.)

K: Pulmonario mollis-Quercetum roboris, Kerecsend (Kevey 2011: 20 felv.)

Zm: Pulmonario mollis-Quercetum roboris, Zámolyi-medence (KeveY et al. 2015: 50 felv.)

Th: Pulmonario mollis-Quercetum roboris, Tolnai-hegyhát (KEVEY et al. 2018: 50 felv.)

HN: Pulmonario mollis-Quercetum roboris, Harkány-Nagynyárádi-sík (Kevey 2016: 40 felv.)

\begin{tabular}{|c|c|c|c|c|c|c|c|c|c|c|}
\hline \multirow{2}{*}{ Flóraelemek } & \multicolumn{5}{|c|}{ Csoportrészesedés } & \multicolumn{5}{|c|}{ Csoporttömeg } \\
\hline & Mf & $\mathbf{K}$ & $\mathbf{Z m}$ & Th & HN & Mf & $\mathbf{K}$ & $\mathbf{Z m}$ & Th & HN \\
\hline KOZMOPOLITA & 0,00 & 0,00 & 0,00 & 0,00 & 0,00 & 0,00 & 0,00 & 0,00 & 0,00 & 0,00 \\
\hline Kozmopolita & 3,16 & 0,09 & 1,88 & 2,30 & 1,64 & 0,37 & 0,01 & 0,20 & 0,24 & 0,67 \\
\hline KOZMOPOLITA s.l. & 3,16 & 0,09 & 1,88 & 2,30 & 1,64 & 0,37 & 0,01 & 0,20 & 0,24 & 0,67 \\
\hline CIRKUMPOLÁRIS & 0,00 & 0,00 & 0,00 & 0,00 & 0,00 & 0,00 & 0,00 & 0,00 & 0,00 & 0,00 \\
\hline Cirkumpoláris & 7,76 & 9,20 & 5,86 & 5,84 & 7,57 & 1,62 & 1,90 & 0,85 & 0,85 & 1,28 \\
\hline CIRKUMPOLÁRIS s.l. & 7,76 & 9,20 & 5,86 & 5,84 & 7,57 & 1,62 & 1,90 & 0,85 & 0,85 & 1,28 \\
\hline EURÁZSIAI & 0,00 & 0,00 & 0,00 & 0,00 & 0,00 & 0,00 & 0,00 & 0,00 & 0,00 & 0,00 \\
\hline Eurázsiai & 27,30 & 24,53 & 23,60 & 23,14 & 26,40 & 14,21 & 5,11 & 7,06 & 5,20 & 12,27 \\
\hline Dél-eurázsiai & 1,25 & 0,95 & 0,64 & 1,59 & 2,53 & 0,18 & 0,09 & 0,06 & 0,15 & 0,67 \\
\hline Közép-eurázsiai & 1,82 & 1,71 & 1,13 & 1,39 & 0,87 & 0,67 & 0,16 & 1,77 & 0,29 & 0,12 \\
\hline EURÁZSIAI s.l. & 30,37 & 27,19 & 25,37 & 26,12 & 29,80 & 15,06 & 5,36 & 8,89 & 5,64 & 13,06 \\
\hline EURÓPAI & 0,00 & 0,00 & 0,00 & 0,00 & 0,00 & 0,00 & 0,00 & 0,00 & 0,00 & 0,00 \\
\hline Európai & 21,12 & 18,79 & 20,51 & 19,36 & 21,02 & 24,16 & 16,61 & 16,64 & 24,43 & 24,54 \\
\hline Közép-európai & 11,62 & 18,31 & 13,21 & 17,09 & 14,77 & 27,59 & 31,05 & 26,74 & 33,63 & 31,71 \\
\hline EURÓPAI s.l. & 32,74 & 37,10 & 33,72 & 36,45 & 35,79 & 51,75 & 47,66 & 43,38 & 58,06 & 56,25 \\
\hline SZUBATLANTI & 0,00 & 0,00 & 0,00 & 0,00 & 0,00 & 0,00 & 0,00 & 0,00 & 0,00 & 0,00 \\
\hline Szubatlanti & 0,13 & 0,00 & 0,16 & 0,02 & 1,23 & 0,38 & 0,00 & 0,02 & 0,00 & 0,91 \\
\hline Amphiatlantikus & 0,00 & 0,00 & 0,00 & 0,00 & 0,05 & 0,00 & 0,00 & 0,00 & 0,00 & 0,01 \\
\hline SZUBATLANTI s.l. & 0,13 & 0,00 & 0,16 & 0,02 & 1,28 & 0,38 & 0,00 & 0,02 & 0,00 & 0,92 \\
\hline SZUBMEDITERRÁN & 0,00 & 0,00 & 0,00 & 0,00 & 0,00 & 0,00 & 0,00 & 0,00 & 0,00 & 0,00 \\
\hline Szubmediterrán & 8,22 & 7,59 & 9,87 & 7,87 & 6,52 & 8,27 & 5,27 & 9,08 & 3,89 & 2,81 \\
\hline Kelet-szubmediterrán & 1,39 & 1,71 & 4,62 & 4,82 & 4,77 & 3,99 & 9,39 & 16,60 & 11,46 & 11,27 \\
\hline Balkáni & 2,83 & 2,99 & 2,19 & 3,55 & 2,19 & 2,73 & 3,91 & 3,30 & 3,69 & 0,57 \\
\hline Nyugat-balkáni & 0,00 & 0,00 & 0,78 & 0,00 & 0,00 & 0,00 & 0,00 & 1,89 & 0,00 & 0,00 \\
\hline Kaukázusi & 0,13 & 0,63 & 0,16 & 0,40 & 0,58 & 0,05 & 3,87 & 0,16 & 0,43 & 0,88 \\
\hline SZUBMEDITERRÁN s.l. & 12,57 & 12,92 & 17,62 & 16,64 & 14,06 & 15,04 & 22,44 & 31,03 & 19,47 & 15,53 \\
\hline KONTINENTÁLIS & 0,00 & 0,00 & 0,00 & 0,00 & 0,00 & 0,00 & 0,00 & 0,00 & 0,00 & 0,00 \\
\hline Kontinentális & 0,72 & 3,61 & 3,08 & 1,06 & 1,19 & 0,07 & 0,34 & 0,33 & 0,10 & 0,13 \\
\hline Szubkontinentális & 1,29 & 0,62 & 1,15 & 1,50 & 0,39 & 1,81 & 0,10 & 1,07 & 0,41 & 0,22 \\
\hline Turáni & 0,29 & 0,00 & 0,00 & 0,00 & 0,00 & 0,03 & 0,00 & 0,00 & 0,00 & 0,00 \\
\hline Pontusi & 3,91 & 6,66 & 5,50 & 5,34 & 3,18 & 3,72 & 8,95 & 7,98 & 8,40 & 1,69 \\
\hline KONTINENTÁLIS s.l. & 6,21 & 10,89 & 9,73 & 7,90 & 4,76 & 5,63 & 9,39 & 9,38 & 8,91 & 2,04 \\
\hline SZUBALPIN & 0,00 & 0,00 & 0,00 & 0,00 & 0,00 & 0,00 & 0,00 & 0,00 & 0,00 & 0,00 \\
\hline Szubalpin & 0,00 & 0,00 & 0,02 & 0,61 & 0,00 & 0,00 & 0,00 & 0,00 & 1,37 & 0,00 \\
\hline SZUBALPIN s.l. & 0,00 & 0,00 & 0,02 & 0,61 & 0,00 & 0,00 & 0,00 & 0,00 & 1,37 & 0,00 \\
\hline PANNONIAI & 0,00 & 0,00 & 0,00 & 0,00 & 0,00 & 0,00 & 0,00 & 0,00 & 0,00 & 0,00 \\
\hline Pannoniai & 1,13 & 1,49 & 2,05 & 1,61 & 0,97 & 0,20 & 3,95 & 2,10 & 0,60 & 0,95 \\
\hline PANNONIAI s.l. & 1,13 & 1,49 & 2,05 & 1,61 & 0,97 & 0,20 & 3,95 & 2,10 & 0,60 & 0,95 \\
\hline ÁZSIAI & 0,00 & 0,00 & 0,00 & 0,00 & 0,00 & 0,00 & 0,00 & 0,00 & 0,00 & 0,00 \\
\hline Nyugat-ázsiai & 0,00 & 0,00 & 0,12 & 0,18 & 0,00 & 0,00 & 0,00 & 0,02 & 0,04 & 0,00 \\
\hline Kis-ázsiai & 0,00 & 0,95 & 0,69 & 0,88 & 0,89 & 0,00 & 9,27 & 3,17 & 4,65 & 8,14 \\
\hline ÁZSIAI s.l. & 0,00 & 0,95 & 0,81 & 1,06 & 0,89 & 0,00 & 9,27 & 3,19 & 4,69 & 8,14 \\
\hline AFRIKAI & 0,00 & 0,00 & 0,00 & 0,00 & 0,00 & 0,00 & 0,00 & 0,00 & 0,00 & 0,00 \\
\hline Afrikai & 0,00 & 0,00 & 0,00 & 0,04 & 0,02 & 0,00 & 0,00 & 0,00 & 0,00 & 0,00 \\
\hline AFRIKAI s.l. & 0,00 & 0,00 & 0,00 & 0,04 & 0,02 & 0,00 & 0,00 & 0,00 & 0,00 & 0,00 \\
\hline ADVENTÍV & 0,00 & 0,00 & 0,00 & 0,00 & 0,00 & 0,00 & 0,00 & 0,00 & 0,00 & 0,00 \\
\hline Adventív & 5,94 & 0,19 & 2,80 & 1,42 & 3,24 & 9,95 & 0,02 & 0,96 & 0,14 & 1,17 \\
\hline ADVENTÍV s.l. & 5,94 & 0,19 & 2,80 & 1,42 & 3,24 & 9,95 & 0,02 & 0,96 & 0,14 & 1,17 \\
\hline
\end{tabular}


8. táblázat A Mezőföld zárt és nyílt lösztölgyeseinek differenciális fajai

Table 8 Differential species in the closed oak forests and open steppe woodlands in the Mezőföld region

PQ: Pulmonario mollis-Quercetum roboris, Mezőföld (Kevey \& Lendvai ined.: 20 felv.)

AcQ: Aceri tatarici-Quercetum pubescentis-roboris, Mezőföld (LENDVAI et al. 2014a: 20 felv.)

\begin{tabular}{|c|c|c|}
\hline & PQ & AcQ \\
\hline \multicolumn{3}{|l|}{ Konstans fajok } \\
\hline Lapsana communis & V & II \\
\hline Brachypodium sylvaticum & V & III \\
\hline Achillea pannonica & - & $\mathrm{V}$ \\
\hline Fragaria viridis & I & V \\
\hline Brachypodium pinnatum & II & V \\
\hline Clinopodium vulgare & II & V \\
\hline Rosa canina agg. & III & V \\
\hline \multicolumn{3}{|l|}{ Szubkonstans fajok } \\
\hline Chelidonium majus & IV & II \\
\hline Ranunculus ficaria & IV & II \\
\hline Adonis vernalis & - & IV \\
\hline Bromus inermis & - & IV \\
\hline Elymus hispidus & - & IV \\
\hline Festuca rupicola & - & IV \\
\hline Filipendula vulgaris & - & IV \\
\hline Peucedanum alsaticum & - & IV \\
\hline Teucrium chamaedrys & - & IV \\
\hline Agrimonia eupatoria & I & IV \\
\hline Dictamnus albus & I & IV \\
\hline Euphorbia cyparissias & I & IV \\
\hline Galium mollugo & I & IV \\
\hline Hypericum perforatum & I & IV \\
\hline Ranunculus polyanthemos & I & IV \\
\hline Silene alba & I & IV \\
\hline Vinca herbacea & I & IV \\
\hline Vincetoxicum hirundinaria & I & IV \\
\hline Campanula bononiensis & II & IV \\
\hline Carex michelii & II & IV \\
\hline Quercus pubescens & II & IV \\
\hline Torilis japonica & II & IV \\
\hline Akcesszórikus fajok & & \\
\hline Parietaria officinalis & III & I \\
\hline Poa nemoralis & III & I \\
\hline Betonica officinalis & - & III \\
\hline Centaurea scabiosa ssp. sadleriana & - & III \\
\hline Galium verum & - & III \\
\hline Salvia pratensis & - & III \\
\hline Securigea varia & - & III \\
\hline Stachys recta & - & III \\
\hline
\end{tabular}

\begin{tabular}{|c|c|c|}
\hline & PQ & AcQ \\
\hline Thalictrum minus & - & III \\
\hline Asparagus officinalis & I & III \\
\hline Buglossoides purpuro-coerulea & I & III \\
\hline Dactylis glomerata & I & III \\
\hline Falcaria vulgaris & I & III \\
\hline Festuca valesiaca & I & III \\
\hline Hylotelephium telephium ssp. maximum & I & III \\
\hline Lactuca quercina ssp. quercina & I & III \\
\hline Melica transsilvanica & I & III \\
\hline Silene vulgaris & I & III \\
\hline Thalictrum aquilegiifolium & I & III \\
\hline Thlaspi perfoliatum & I & III \\
\hline Szubakcesszórikus fajok & & \\
\hline Elymus caninus & II & - \\
\hline Vinca minor & II & - \\
\hline Allium sphaerocephalon & - & II \\
\hline Calamagrostis epigeios & - & II \\
\hline Campanula glomerata & - & II \\
\hline Carex humilis & - & II \\
\hline Chaerophyllum bulbosum & - & II \\
\hline Chenopodium album & - & II \\
\hline Colutea arborescens & - & II \\
\hline Dianthus pontederae & - & II \\
\hline Eryngium campestre & - & II \\
\hline Euphorbia glareosa & - & II \\
\hline Hieracium umbellatum agg. & - & II \\
\hline Inula germanica & - & II \\
\hline Inula hirta & - & II \\
\hline Medicago falcata & - & II \\
\hline Origanum vulgare & - & II \\
\hline Peucedanum cervaria & - & II \\
\hline Phleum phleoides & - & II \\
\hline Plantago media agg. & - & II \\
\hline Potentilla recta & - & II \\
\hline Scorzonera hispanica & - & II \\
\hline Serratula tinctoria & - & II \\
\hline Tanacetum corymbosum & - & II \\
\hline Veronica austriaca & - & II \\
\hline Vicia tenuifolia & - & II \\
\hline Differenciális fajok száma & 8 & 67 \\
\hline
\end{tabular}


KeVey B., HoRváth A. \& LendVAi G. (2019):

Zárt lösztölgyes maradványok a Mezőföldön (Pulmonario mollis-Quercetum roboris Kevey 2008) / Remnants of closed oak woods on loess in the Mezőföld (Pulmonario mollis-Quercetum roboris Kevey 2008)

Kitaibelia 24(1): 66-93.

DOI: 10.17542/kit.24.66

Elektronikus melléklet / Electronic appendix

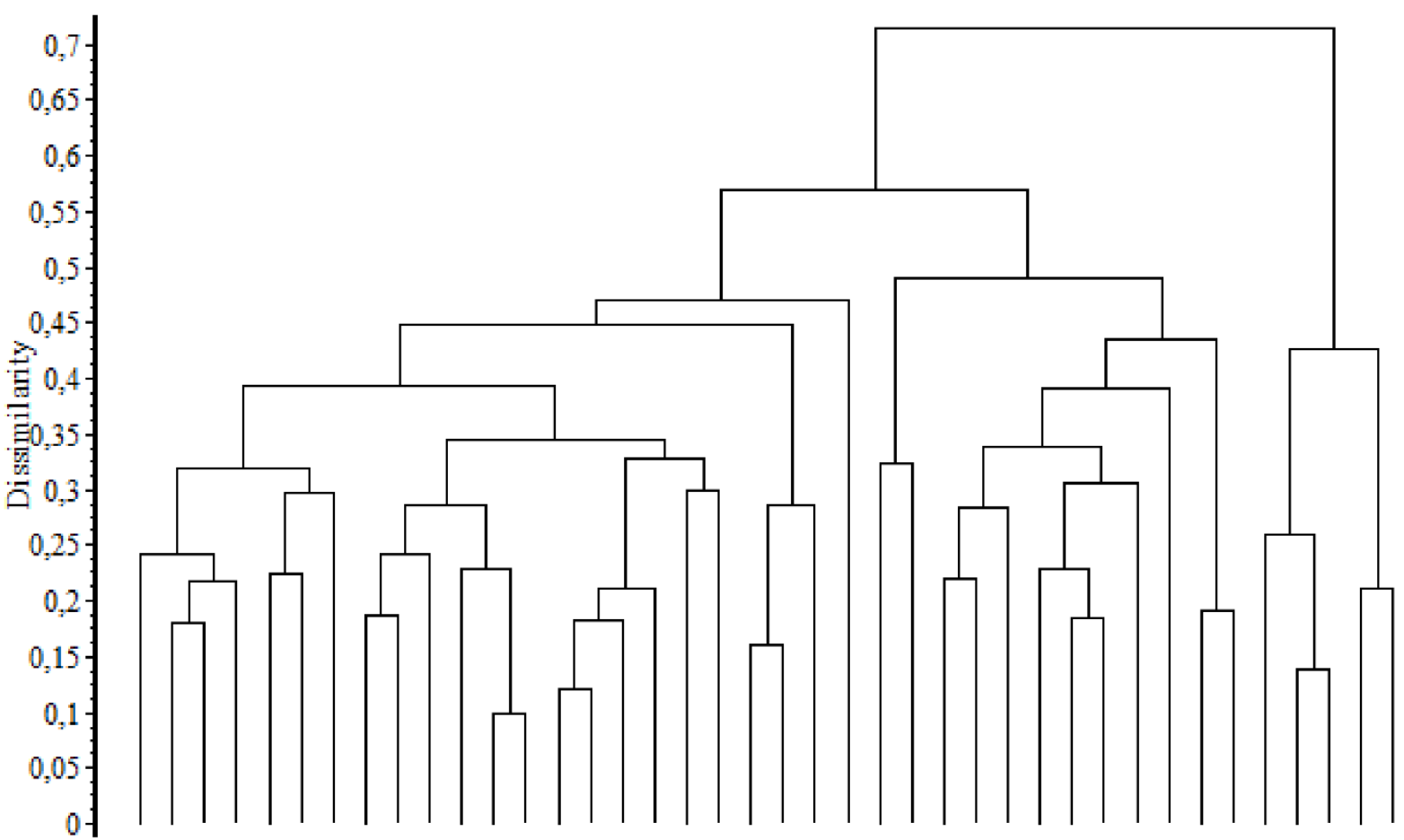

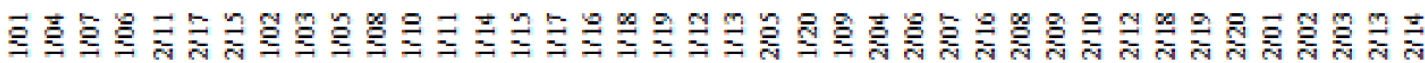

e1. ábra Zárt és nyílt lösztölgyes felvételek bináris dendrogramja I.

(hasonlósági index: Baroni-Urbani-Buser; osztályozó módszer: teljes lánc)

eFig. 1 Binary dendrogram of samples from closed oak woods and open steppe woodlands.

(similarity coefficient: Baroni-Urbani-Buser; clustering method: complete link)

1/1-20: Pulmonario mollis-Quercetum roboris (Kevey és Lendvai ined.)

2/1-20: Aceri tatarici-Quercetum pubescentis-roboris (LENDVAI et al. 2014a) 


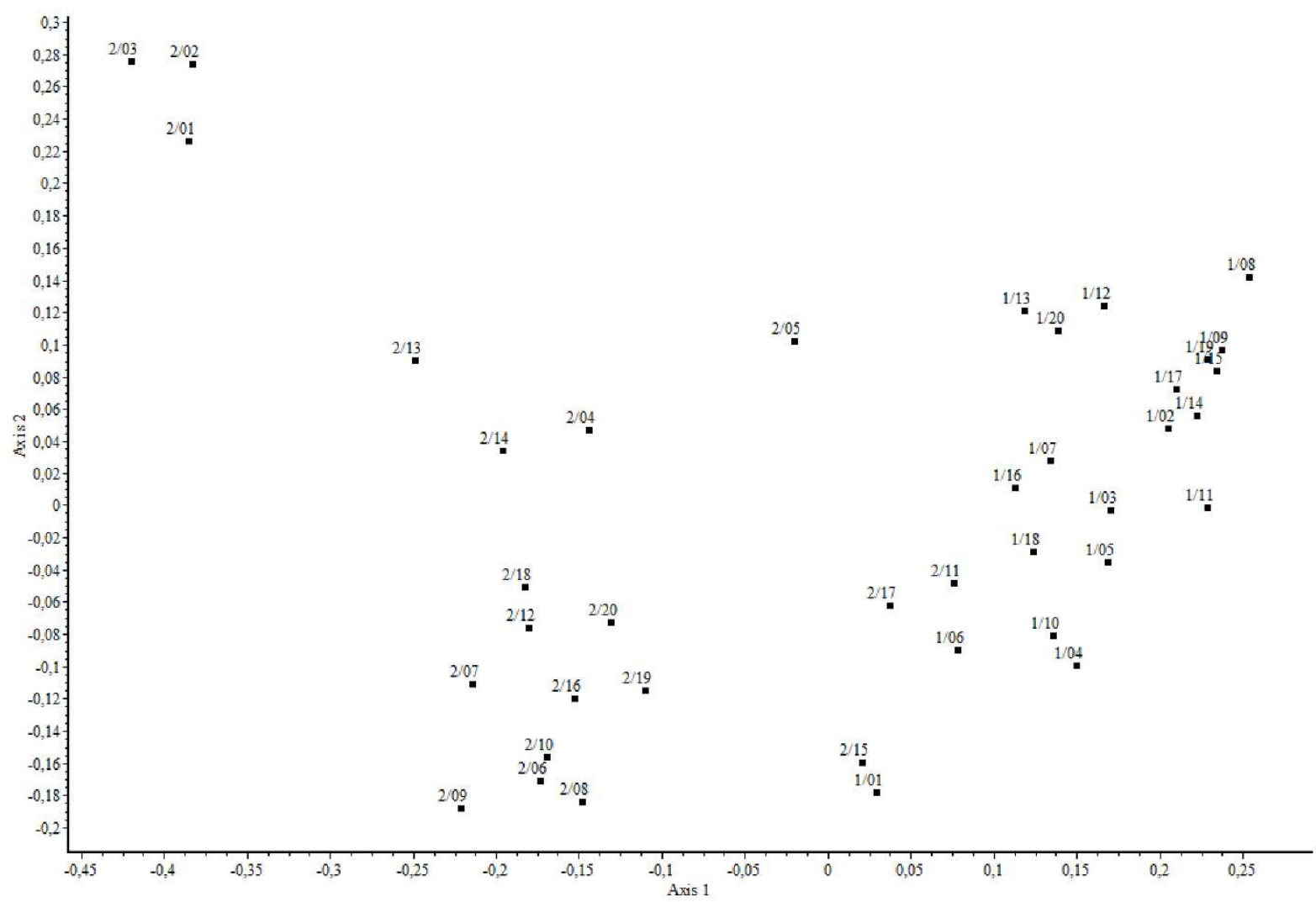

e2. ábra Zárt és nyílt lösztölgyes felvételek bináris ordinációs diagramja I.

(hasonlósági index: Baroni-Urbani-Buser; ordinációs módszer: főkoordináta-analízis)

eFig. 2 Binary ordination diagram of samples from closed oak woods and open steppe woodlands.

(similarity coefficient: Baroni-Urbani-Buser; ordination method: principal coordinates analysis)

1/1-20: Pulmonario mollis-Quercetum roboris (Kevey és Lendvai ined.)

2/1-20: Aceri tatarici-Quercetum pubescentis-roboris (LENDVAI et al. 2014a) 